\title{
A Review of Radioactive Waste Immobilization in Concrete
}

\author{
R. O. Lokken
}

June 1978

Prepared for the U.S. Department of Energy under Contract No. EY-76-C-06-1830

Pacific Northwest Laboratory Operated for the U.S. Department of Energy by 


\title{
NOTICE
}

This report was prepared as an account of work sponsored by the Unired States Covernment. Neither the United States nor the Department of Energy, nor any of their employces, nor any of their contractors. subcontractors, or their employees, makes any warranty. express or imolied, or assumes any legai liability or cesponsibility for the accuracy, completeness or usefuiness of any intormation, apparatus, product or process disciosed, or represents that its use would not iniringe privately owned rights.

The views, opinions and conclustons contained in this report are those of the contractor and do not necussatily represent those of the United States Covernment or the United States Department af Energy.

\author{
PACIFIC NORTHWEST LABORATORY \\ operated by \\ BATTELLE \\ for the \\ UNITED STATES DEPARTMENT OF ENERCY \\ Under Contract EY-76-C-06-1330
}

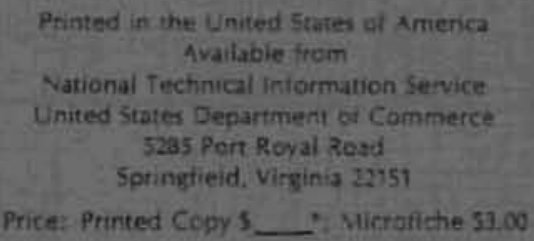


A REVIEW OF RADIOACTIVE WASTE IMMOBILIZATION IN CONCRETE

R. 0. Lokken

June 1978

Prepared for

the U.S. Department of Energy

under Contract No. EY-76-C-06-1830

Pacific Northwest Laboratory

Richland, Washington 99352 
$-$ 


\section{SUMMARY}

The first section of this report discusses properties of concrete waste forms obtained through a literature review on research and development activities associated with immobilization of radioactive wastes in concrete. Types of radioactive waste discussed include low-level and intermediate-level radioactive waste, simulated defense high-level waste sludges and calcines, simulated neutralized AGNS acid fuel reprocessing waste and simulated power reactor fuel cycle HLW calcines. The waste form properties, discussed in terms of their dependency on waste type and amount, include water/cement ratio, set times, curing exotherms, compressive strength, impact strength, strontium, cesium, and transuranics leachabilities, thermal conductivity, thermal stability, and radiation stability. This report does not include reported experimental procedures.

The second section discusses conditions and restrictions that govern the feasibility of immobilizing HLW in concrete. Results of theoretical calculations based on the thermal characteristics of radioactive waste forms are discussed and illustrated in 11 figures and 4 tables. Waste loadings, as dictated by these characteristics, subsequently define material requirements; 5 figures and 9 tables illustrate the effect of waste loading on material requirements. Also discussed is a comparison of selected properties of glass waste forms and concrete waste forms, and reported properties of hot-pressed cement used for the solidification of radioactive wastes. A conceptual process for HLW immobilization in concrete is discussed with major emphasis on processing problems associated with heat and radiation effects on water. Since the current U.S. policy indefinitely postpones LWR fuel reprocessing, discussions on the solidification of LWR wastes are presented solely for the purpose of comparison with other solidification options and with other wastes incorporated in concrete.

Use of hydraulic cements for the solidification of various low heat generating wastes was shown to produce products with acceptable properties. However, high heat generating rates ( $\sim 9.2 \mathrm{~kW} / \mathrm{MTU}$ ) and high radioactivity 
levels ( $\left.1.6 \times 10^{6} \mathrm{Ci} / \mathrm{MTU}\right)$ of HLW appear to have detrimental effects on the fedsibility assessment of concrete waste forms. More elaborate offgas and cooling facilities are required during processing because of possible radiolytic gas production and water vaporization. Hot-pressed cement appears a more attractive mechanism for HLW immobilization because of improved physical properties and reduced material requirements. The overall feasibility, however, is governed by processing complexity. 


\section{CONTENTS}

SUMMARY. . . . . . . . . . . . . . . . . . . . . . . . i i

LIST OF FIGURES. . . . . . . . . . . . . . . . . . . . . . . vij LIST OF TABLES . . . . . . . . . . . . . . . . . . . . . ix INTRODUCTION . . . . . . . . . . . . . . . . . . . . . 1

CEMENTS USED IN STUDIES. . . . . . . . . . . . . . . . . . . 3

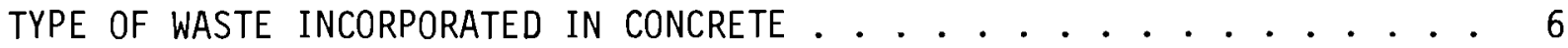

LOW- AND INTERMEDIATE-LEVEL WASTES. . . . . . . . . . . . . 6

DEFENSE HIGH-LEVEL WASTES . . . . . . . . . . . . . . . . 7

CEMENT/IVASTE COMPOSITES. . . . . . . . . . . . . . . . . . 10

COMPRESSIVE STRENGTH. . . . . . . . . . . . . . . . 15

LEACHABILITY. . . . . . . . . . . . . . . . . . 25

Strontium Leachability . . . . . . . . . . . 25

Cesium Leachability. . . . . . . . . . . . . 29

Alpha Emitter Leachability.............. . 32

Sodium Nitrate Leachability. . . . . . . . . . . 32

Polymer-Impregnated Concrete . . . . . . . . . . 33

THERMAL ANALYSIS. . . . . . . . . . . . . . . . . 35

Thermal Conductivity ............... 35

DTA-TGA-EGA. . . . . . . . . . . . . . . . 37

RADIOLYTIC GAS PRODUCTION . . . . . . . . . . . . . . . . 39

LITERATURE REVIEW SECTION SUMMARY. . . . . .............. . 41

FEASIBILITY OF INCORPORATING HIGH ACTIVITY WASTE IN CONCRETE . . . . • 43

LITERATURE REVIEW .................... 43

DISCUSSION. . . . . . . . . . . . . . . . . . . 44 
Heat Transfer and Waste Loading Considerations . . . . . 44

Comparison of Concrete and Borosilicate Glass. . . . . . . 48

Potential Processing Problems. . . . . . . . . . . 48

Encapsulation in Hot-Pressed Cement. ........ 51

Conceptual HLW Immobilization Process. . . . . . . . . 53

FEASIBILITY SECTION SUMMARY. . . . . . . . . . . . . . 56

CONCLUSIONS. .......................... 58

REFERENCES ............................. 91 
FIGURES

1 Compressive Strength of Concrete Waste Forms Containing Simulated SRP Sludge I. . . . . . . . . . . . . . . . 19

2 Compressive Strength of Concrete Waste Forms Containing Simulated SRP Sludge II . . . . . . . . . . . . . . 20

3 Compressive Strength of Concrete Waste Forms Containing Simulated SRP Sludge III. . . . . . . . . . . . . . . . 21

4 Fractional Change in Waste Loading Requirements as a Function of Canister Diameter . . . . . . . . . . . . . 62

5 Canister Centerline Temperature as a Function of Diameter and Thermal Conductivity. . . . . . . . . . . . . 65

6 Canister Centerline Temperature as a Function of Diameter and Volumetric Heat Generation. . . . . . . . . . . . . 66

7 Canister Centerline Temperature as a Function of Thermal Conductivity and Volumetric Heat Generation . . . . . . . . . 67

8 Canister Centerline Temperature as a Function of Thermal Conductivity and Volumetric Heat Generation . . . . . . . . 68

9 Canister Centerline Temperature as a Function of Thermal Conductivity and Volumetric Heat Generation . . . . . . . . 69

10 Canister Centerline Temperature as a Function of Thermal Conductivity and Diameter . . . . . . . . . . . . . . 70

11 Canister Centerline Temperature as a Function of Volumetric Heat Generation and Diameter. . . . . . . . . . . . . 71

12 Canister Centerline Temperature as a Function of Volumetric Heat Generation and Diameter. . . . . . . . . . . . 72

13 Volumetric Heat Generation as a Function of Diameter and Thermal Conductivity. . . . . . . . . . . . . . . . 75

14 Volumetric Heat Generation as a Function of Diameter and Thermal Conductivity. . . . . . . . . . . . . . 76

15 Number of Canisters Required per Year as a Function of Diameter and Thermal Conductivity . . . . . . . . . . . 78

16 Number of Canisters Required per Year as a Function of Diameter and Thermal Conductivity .. . . . . . . . . . . 79 
17 Annual Canister Weight as a Function of Diameter and Thermal Conductivity. . . . . . . . . . . . . . 80

18 Annual Canister Weight as a Function of Diameter and Thermal Conductivity. ............... . 81

19 Radioactivity Decay Heat as a Function of Time Out of Reactor................. 82

20 Canister Centerline Temperature as a Function of Time Out of Reactor................. 85

21 Splitting Tensile Strength of Hot-Pressed Cement Containing $\mathrm{PW}-4 \mathrm{C}$. . . . . . . . . . . . . 87 


\section{TABLES}

1 Relative Composition of Portland Cements. . . . . . . . 5

2 Typical Water/Cement (W/C) Ratios for Various Neat Cements. . . . 5

3 Composition of Simulated Sludges. . . . . . . . . . 9

4 Composition of Washed, Dried SRP Waste Sludges......... 9

5 Parameters Calculated for Various Cement-Sludge

Combinations. . . . . . . . . . . . . . . 11

6 Compressive Strengths of Neat Cement Pastes . . . . . . . . 16

7 Compressive Strengths of Concrete Waste Forms . . . . . . . . 17

8 Typical Compressive Strengths of Concrete Waste Forms With $40 \%$ Simulated SRP Sludge Heated at $100^{\circ} \mathrm{C} \ldots . . . . .24$

9 Relative Impact Resistance of Various Waste Forms . . . . . . 24

10 Reported Strontium Leach Data for Various Concrete Waste Forms. . . 27

11 Reported Cesium Leach Data for Various Concrete Waste Forms . . . 30

12 Reported Sodium Nitrate Leach Data for Various Concrete Waste Forms . . . . . . . . . . . . . . . . 34

13 Thermal Conductivity of Various Waste Forms . . . . . . . 36

14 Typical Reactions Occurring in Heated Concrete Waste Forms. . . . 38

15 Material Requirements for the Incorporation of Radioactive Waste in Concrete............... 60

16 Material Requirements for the Incorporation of Radioactive Waste in Concrete.............. . 61

17 Canister Centerline Temperature as a Function of Diameter and Thermal Conductivity............. 63

18 Canister Centerline Temperature as a Function of Diameter and Volumetric Heat Generation. . . . . . . . . . . . . . 64

19 Maximum Diameter for Various Temperatures as a Function of Thermal Conductivity .............. . . 73

20 Maximum Allowable Volumetric Heat Generation as a Function of Diameter and Thermal Conductivity. . . . . . . . . . 74 
21 Number of Canisters Required to Encapsulate 1500 MTU Waste as a Function of Diameter and Thermal Conductivity. . . . . . 77

22 Requirements for the Immobilization of Radioactive Waste in Concrete. . . . . . . . . . . . . . . . . 83

23 Requirements for the Immobilization of Radioactive Waste in Concrete. . . . . . . . . . . . . . . . . . 84

24 Comparison of Requirements for the Immobilization of Radioactive Waste in Concrete and Borosilicate Glass. . . . . . . . 86

25 Requirements for the Incorporation of Radioactive Waste in Hot-Pressed Cement with a Limiting Temperature of $400^{\circ} \mathrm{C}$. . . . 88

26 Requirements for the Incorporation of Radioactive Waste in Hot-Pressed Cement with a Limiting Temperature of $700^{\circ} \mathrm{C}$. . . 89

27 Requirements for the Conceptual Process for HLW Immobilization in Concrete. . . . . . . . . . . . . . . . 9 90 


\section{INTRODUCTION}

Currently only small amounts of light water reactor (LWR) fuel cycle high level liquid waste (HLLW) have been generated in the United States. This HLLW, generated at the Nuclear Fuel Services Plant at West Valley, New York, during the years 1966-1972, is now in storage. (1) Present regulations require that should additional commercial HLLW ever be generated in the U.S. it must be converted to a stable, dry solid within five years after fuel reprocessing. (1) However, it is also noted that since there are no plans in the U.S. to reprocess LWR fuels, commercial solidification of HLLW is not being performed. Several HLLW solidification processing options are ready for demonstration on a commercial scale, along with other options currently in the developmental stage. ${ }^{(2)}$ Should reprocessing and solidification be implemented, all the solidification options must be capable of converting HLLW into a dry solid which meets or exceeds the criteria established concerning chemical, thermal, mechanical, and radiolytic stability. Furthermore, since the specific criteria for the waste forms have not been established, all viable solidification mechanisms are potential candidates.

For many years concrete has been considered for, or used for the solidification of low-level and intermediate-level radioactive wastes. ${ }^{(3-15)}$ Concrete is considered attractive because the raw materials are inexpensive, only ambient temperatures are required, and processing operations are relatively simple. For these reasons concrete has been considered an alternative for the solidification of defense high-level radioactive waste stored at the Savannah River Plant (SRP), (16) Idaho Chemical Processing Plant (ICPP), (17) and Hanford. ${ }^{(18)}$ Extensive programs have been conducted at Savannah River Laboratory (SRL), $(19-33)$ and Brookhaven National Laboratory $(B N L)(34-40)$ on the incorporation of SRP waste sludges in concrete. Other types of radioactive wastes considered for solidification in concrete include Redox ${ }^{(41)}$ and Purex ${ }^{(42)}$ sludges, aqueous and solid sodium nitrate wastes, $(38-40,43-46)$ various solid calcines, ${ }^{(43-52)}$ tritium, ${ }^{(53-61)}$ radioactive iodine, ${ }^{(62)}$ and solids loaded with krypton-85. (63) The advantages and usage of concrete for fixation of these waste types suggest the possibility of incorporating high specific activity wastes in concrete. 


\section{OBJECTIVE}

The objective of this report is to provide a general overview of developmental activities and physical, chemical, and thermal characteristics of concrete composites used for the solidification of various radioactive wastes. Included are brief descriptions of the hydraulic cements used, their basic characteristics, the types of radioactive and simulated wastes reported, and characteristics of cement/waste composites. A discussion on the applicability of using hydraulic cements for solidification of high specific activity wastes, such as those from LWR fuel cycles, is also presented. The conclusions of this review may provide a basis for recommendations for further developmental activities on LWR waste incorporation in concrete.

This report presents and describes results obtained from a literature review of research and development activities directly associated with the solidification and fixation of radioactive wastes in concrete; however, it is not intended to encompass the entire spectrum of activity in this area. Experimental methods and procedures are not described in detail. More emphasis is placed on recent developments with defense high-level waste. Discussions related to LWR waste solidification are included solely for comparison with existing technologies since current U.S. policy does not include LWR fuel reprocessing which subsequently eliminates solidification of HLLW. 


\section{CEMENTS USE IN STUDIES}

A mixture of hydraulic cement (that which reacts with water to form pastes that set and harden), water, and aggregate is referred to as "concrete." Aggregate in commercial concrete usually consists of sand and gravel; however, for the purpose of solidifying radioactive wastes the aggregate consists of various forms of the waste. Three commonly used types of hydraulic cements used in making concrete include portland cement, portland-pozzolanic cement, and high-alumina cement. The major constituents of these cements are various calcium silicates and calcium aluminates.

Five types of portland cement have been defined and consist mainly of tricalcium silicate $\left(3 \mathrm{CaO} \cdot \mathrm{SiO}_{2}\right)$, dicalcium silicate $\left(2 \mathrm{CaO} \cdot \mathrm{SiO}_{2}\right)$, tricalcium aluminate $\left(3 \mathrm{CaO} \cdot \mathrm{Al}_{2} \mathrm{O}_{3}\right)$, and tetracalcium aluminoferrite $\left(4 \mathrm{CaO} \cdot \mathrm{Al}_{2} \mathrm{O}_{3} \cdot \mathrm{Fe}_{2} \mathrm{O}_{3}\right) .{ }^{(54)}$ Relative compositions of types $\mathrm{I}-\mathrm{V}$ portland cement are give in Table 1. Type I portland cement is norma 1, general purpose cement. Type II is modified to yield a lower heat of hydration than type I, is low alkali, and has better sulfate resistance. Type III develops a large fraction of its ultimate strength in three days and has a larger heat generation rate than type I. Type IV has a low rate and amount of heat generation. Type $V$ is formulated to resist severe sulfate attack. Type I-P cement is a standard portland-pozzolanic cement with $80 \%$ type I plus $20 \%$ fly-ash $\left(\mathrm{SiO}_{2}\right)$. Fly-ash enhances the cementitious properties of portland cements by reacting with the calcium hydroxide formed during the hydration of cement. High-alumina cement (HAC) is composed primarily of monocalcium aluminate $\left(\mathrm{CaO} \cdot \mathrm{Al}_{2} \mathrm{O}_{3}\right)$.

Hydration of the compounds in cement is a necessary condition for the setting and subsequent hardening of cement paste into concrete. Cementitious hydrates and calcium hydroxide are the reactants in portland cement that satisfy the above condition. The $\mathrm{Ca}(\mathrm{OH})_{2}$ produced during hydration of portland cements does not exhibit cementitious properties; however, the pozzolan (fly-ash) in portland-pozzolanic cement reacts with $\mathrm{Ca}(\mathrm{OH})_{2}$ to form compounds which possess cementitious properties. Highalumina cement reacts with water to form cementitious, hydrated calcium 
aluminate and aluminum hydroxide. Both $\mathrm{Al}(\mathrm{OH})_{3}$, formed by hydration of high-alumina cement, and $\mathrm{Ca}(\mathrm{OH})_{2}$, formed by hydration of portland cement, are non-cementitious. Calcium hydroxide may contribute to long-term detrimental effects on overall concrete stability; aluminum hydroxide, on the other hand, does not cause these severe effects.

Cement types differ in the amount of water required to form a paste with "ideal workability." The water/cement ratio $(\mathrm{w} / \mathrm{c})$ is dependent on the relative amount of individual cement components and general stoichiometry of the hydrated and hydroxylated compounds. Some typical water/cement ratios for various neat cement pastes are shown in Table 2.

Set times also vary with different types of cement and conditions. A cement-water paste is considered "set" when sufficient hydration has taken place to give the mix a friable rigidity. Two methods of increasing concrete set times are through addition of set retarders and/or excess water. Set retarders alter the rate of hydration though not affecting the nature of the hydrated species in cements. Retarders may be either organic or inorganic in nature. Organic retarders include derivatives of hydroxylated carboxylic acid and their salts and derivatives of lignin, such as lignosulfonic acid and their salts. Inorganic retarders include zinc salts, phosphates, silicoflourides, boric acid and borax. ${ }^{(31)}$ Excess water is generally undesirable because physical properties can be seriously degraded by excess water in concrete. 
TABLE 1. Relative Composition of Portland Cements

\begin{tabular}{|c|c|c|c|c|}
\hline \multirow[b]{2}{*}{ Cement Type } & \multicolumn{4}{|c|}{ Composition, wt\% } \\
\hline & $\underline{c}_{3} s^{\mathrm{a}}$ & $c_{-2} s^{b}$ & $\underline{C}_{3} A^{\mathrm{C}}$ & $\mathrm{C}_{-4} \mathrm{AF}^{\mathrm{d}}$ \\
\hline I & 45 & 27 & 11 & 8 \\
\hline II & 44 & 31 & 7 & 13 \\
\hline III & 53 & 19 & 10 & 7 \\
\hline IV & 20 & 53 & 6 & 14 \\
\hline v & 38 & 43 & 4 & 8 \\
\hline
\end{tabular}
(a) Tricalcium silicate - $3 \mathrm{CaO} \cdot \mathrm{SiO}_{2}$
(b) Dicalcium silicate - $2 \mathrm{CaO} \cdot \mathrm{SiO}_{2}$
(c) Tricalcium aluminate - $3 \mathrm{CaO} \cdot \mathrm{Al}_{2} \mathrm{O}_{3}$
(d) Tetracalcium aluminoferrite $-4 \mathrm{CaO} \cdot \mathrm{Al}_{2} \mathrm{O}_{3} \cdot \mathrm{Fe}_{2} \mathrm{O}_{3}$

TABLE 2. Typical Water/Cement (W/C) Ratios for Various Neat Cements

\section{Cement Type}

Portland I

Portland II

Portland III

Portland $V$

Type I-P

HAC
Wa ter/Cement

Ratio

$0.323^{(33)}$

$0.26^{(35)}$

$0.278^{(33)}$

$0.303^{(33)}$

$0.286^{(33)}$

$0.323^{(33)}$

$0.332^{(33)}$

$0.22^{(34,44)}$

$0.234^{(33)}$

$0.24^{(35)}$

$0.257^{(33)}$ 


\section{TYPE OF WASTE INCORPORATED IN CONCRETE}

\section{LOW- AND INTERMEDIATE-LEVEL WASTES}

For the purpose of discussion, low-level waste (LLW) and intermediatelevel waste (ILW) are defined as: (16)

- Low-Level Waste - Wastes containing types and concentrations of radioactivity such that shielding to prevent personnel exposure is not required.

- Intermediate-Level Waste - Wastes requiring some kind of action to protect personnel from radiation.

Numerous types of low-level, LWR radwaste have been considered for solidification in concrete. ${ }^{(3-13)}$ These wastes are usually liquid concentrates and solid waste generated as by-products of the liquid radwaste treatment systems in LWR's. Wet solid wastes constitute the major solid waste on an activity basis and can be classified into four basic types: ${ }^{(12)}$

- Spent resins

- Filter sludges

- Evaporator concentrates

- Miscellaneous liquids

The spent resins result from liquid waste demineralization, coolant cleanup, BWR condensate polishing, and fuel storage pool cleanup. Filter sludges consist of powdered resin from precoat filter/demineralizers and filter aid material from precoat filters. Evaporator concentrates consist primarily of sodium sulfate solutions from the regeneration of condensate polishers in BWR's and boric acid solutions from PWR coolant adjustment. Some liquid wastes can be solidified directly without concentration. (12) Developmental testing has been conducted with solid wastes of low specific activity (LSA) incorporated in concrete. These wastes, in the form of radioactive filter sludges, spent resins and chemical wastes, result from treatment of condensed primary steam from BWR's and water from other sources in the plant. 
Hanford Engineering Development Laboratories (HEDL) has conducted labortory studies on fixation of waste residues from simulated alpha wastes. (3) Alpha wastes refer to non-high-level wastes containing measurable or suspended contamination from actinide elements. Three types of waste incorporated in concrete include Acid Digestion Test Unit (ADTU) residue dehydrated at $350^{\circ} \mathrm{C}$, filter residue, and ion exchange resin. Developmental activities with low-level radioactive wastes at Los Alamos Scientific Laboratory (LASL) have also included incorporation of wastes in concrete matrices. (9) The alpha activity of the liquid waste is concentrated into sludges through ferric hydroxide precipitation processes. The sludges can then be mixed with cement and water and transported to various disposal sites. The alpha activity of the raw waste sludges is $210 \mathrm{nCi} / \mathrm{g}$. Numerous other sites in the United States, Czechoslavakia, France, and India have incorporated various low-level radioactive wastes in concrete. (3)

Oak Ridge National Laboratory (ORNL) has blended over one million gallons of intermediate-level waste solution with cement and clays and injected the waste mixture into cracks produced in shale formations. $(14,15)$ The ILW is composed of a mixture of all the liquid wastes produced in hotce11, pilot plant, and reactor operations; it does not include process wastes, however. The beta-gamma activity after concentration of the solution is generally $\leq 2 \mathrm{Ci} / \mathrm{gal}$ with ${ }^{137} \mathrm{Cs}$ being the major radionuclide; alpha activity is $\sim 1 \mathrm{mCi} / \mathrm{gal}$. Aqueous sodium nitrate waste based on neutralized AlliedGeneral Nuclear Services (AGNS) acid fuel reprocessing waste has been investigated at Brookhaven National Laboratory (BNL) for incorporation in concrete. $(38-40,43-46)$ AGNS neutralized waste is $22.5 \underline{M ~ N a N O}_{3}$ with $\sim 1 \times 10^{-4} \mathrm{M}$ cesium and strontium.

\section{DEFENSE HIGH-LEVEL WASTES}

Defense wastes are defined as nuclear wastes generated from government defense programs for plutonium production. ${ }^{(18)}$ Defense high-level radioactive wastes are stored in underground tanks as alkaline liquids with precipitated sludge layers at Hanford ${ }^{(18)}$ and Savannah River. (16) After the radioactivity decay heat has diminished to an acceptable level, water is evaporated from the liquid waste to form salt cake to reduce volume and mobility. The 
radioactive liquid waste at Idaho Chemical Processing Plant is presently being converted to a granular calcine, then stored in underground, stainless steel bins in reinforced concrete vaults. (17)

Extensive studies on incorporation of simulated SRP waste in concrete have been conducted by Savannah River Laboratory $(19-33)$ and by Brookhaven National Laboratory. $(34-40)$ Three compositions of simulated washed, dried sludges were used in the initial investigations: ${ }^{(21)}$

- Sludge I : 50 mole $\% \mathrm{Fe}(\mathrm{OH})_{3}, 50 \mathrm{~mole} \% \mathrm{Ar}(\mathrm{OH})_{3}$

- Sludge II : $40 \% \mathrm{Fe}(\mathrm{OH})_{3}, 40 \% \mathrm{Al}(\mathrm{OH})_{3}, 20 \% \mathrm{HgO}$

- Sludge III: $50 \% \mathrm{Fe}(\mathrm{OH})_{3}, 50 \% \mathrm{MnO}$

These sludges are hydrous oxides of the base metals formed by caustic precipitation from metal nitrate solutions. Each sludge also contained $2400 \mathrm{ppm}$ strontium. Measured compositions of the three sludges are given in Table 3.

Following initial studies with simulated SRP waste sludges, SRL incorporated actual radioactive sludges in concrete on a lab-scale basis. $(24,33)$ The sludges were removed from three tanks at SRP. Compositions of the sludges are given in Table 4 . The major radionuclide activity in the sludges is contributed by ${ }^{90} \mathrm{Sr}$ which ranges from $\sim 16$ to $75 \mathrm{mCi} / \mathrm{g}$. Gross alpha activity ranges from $\sim 0.1$ to $0.3 \mathrm{mCi} / \mathrm{g}$.

Incorporation of simulated Hanford wastes in concrete has also been investigated. $(41,42)$ Two types of simulated sludges were used in the investigations:

- Synthetic washed, dried Redox sludge ${ }^{(41)}$

- Synthetic washed, dried Purex sludge ${ }^{(42)}$

Compositions of these synthetic sludges are given in Table 3.

Simulated Idaho Chemical Processing Plant (ICPP) calcine has been incorporated in concrete by Idaho National Engineering Laboratory (INEL) ${ }^{(47)}$ and BNL. $(43,44,45)$ 
TABLE 3. Composition of Simulated Sludges, wt\%

\begin{tabular}{|c|c|c|c|c|c|}
\hline & $\begin{array}{c}\text { SRP } \\
\text { Sludge } \\
\text { I (33) } \\
\end{array}$ & $\begin{array}{c}\text { SRP } \\
\text { Sludge } \\
\text { II (33) } \\
\end{array}$ & $\begin{array}{c}\text { SRP } \\
\text { SI udge } \\
\text { II I (33) } \\
\end{array}$ & $\begin{array}{c}\begin{array}{c}\text { Manford } \\
\text { Redox }\end{array} \\
\text { Sludge } \\
\end{array}$ & $\begin{array}{l}\text { Hanford } \\
\text { Purex } \\
\text { Sludge }\end{array}$ \\
\hline $\mathrm{Fe}$ & 32.86 & 20.43 & 23.42 & 2.7 & 22.4 \\
\hline A1 & 15.20 & 9.23 & & 22.6 & 8.3 \\
\hline $\mathrm{Hg}$ & & 38.23 & & & \\
\hline Mn & & 0.35 & 23.56 & 0.09 & 2.5 \\
\hline$S r$ & 0.04 & 0.02 & 0.04 & 1.8 & 1.0 \\
\hline $\mathrm{Na}$ & 1.08 & 0.18 & 2.26 & 3.9 & 4.8 \\
\hline k & & 0.05 & 1.09 & & \\
\hline $\mathrm{Cr}$ & & & & 1.9 & \\
\hline Si & & & & 5.2 & 6.4 \\
\hline $\mathrm{Ca}$ & & & & & 0.5 \\
\hline $\mathrm{NO}_{3}^{-}$ & 2.97 & & & & \\
\hline $\mathrm{PO}_{4}{ }^{3-}$ & & & & & 2.2 \\
\hline $\mathrm{H}_{2} \mathrm{O}$ & 19.90 & 10.30 & 25.70 & 30.0 & 26.0 \\
\hline $0^{\mathrm{a}}$ & 27.95 & 20.71 & 23.93 & & \\
\hline $\mathrm{O}_{2} \mathrm{~b}$ & & & & 31.0 & 26.0 \\
\hline
\end{tabular}

TABLE 4. Compositigin of Washed, Dried SRP Waste
Sludges

\begin{tabular}{|c|c|c|}
\hline Tank 5 & Tank 13 & $\overline{T \text { Tank } 1}$ \\
\hline 27.5 & 27.9 & 3.1 \\
\hline 10.8 & 8.8 & 2.3 \\
\hline 1.5 & 7.1 & 33.5 \\
\hline 15.4 & 4.0 & 0.9 \\
\hline 6.1 & 3.1 & 1.2 \\
\hline 0.6 & 2.3 & 0.2 \\
\hline 0.1 & 2.1 & 0.9 \\
\hline 5.1 & 0.5 & 0.5 \\
\hline
\end{tabular}




\section{CEMENT/WASTE COMPOSITES}

Commercial concrete contains sand and gravel as inert aggregate, that is, the water/cement ratio $(\mathrm{w} / \mathrm{C})$ is not changed with aggregate additions. When various waste forms are added as agqreqate in cement pastes, the values of $w / c$ may increase due to the hydrophylic nature of the dry wastes. $(33,35)$ This phenomenon has been studied with simulated SRP sludges. (33) The total water required for ideal consistency of a cement/waste mixture should be the water required by the cement plus the water required by the sludge. However, workers at SRL found this not to be the case. ${ }^{(33)}$ They have shown that cements and simulated SRP sludges may interact causing variations from expected $\mathrm{w} / \mathrm{C}$ ratios. The total amount of water required for cement/sludge mixtures can be expressed as:

$$
w=w_{c}+w_{s}[1+a(s / c)]
$$

where,

$$
\begin{aligned}
w_{c} & =\text { water required by cement } \\
w_{S} & =\text { water required by sludge } \\
s / c & =\text { weight ratio of sludge to cement } \\
a & =\text { interaction coefficient for each cement-sludge pair }
\end{aligned}
$$

This equation can also be expressed as:

$$
w / c=\left(w_{c} / c\right)+\left(w_{s} / s\right)(s / c)+a\left(w_{s} / s\right)(s / c)^{2}
$$

where,

$$
\begin{aligned}
w / c & =\text { weight ratio of water to cement } \\
w_{c} / c & =\text { water required per gram of cement } \\
w_{s} / s & =\text { water required per gram of sludge }
\end{aligned}
$$

Table 5 lists parameters calculated for combinations of six types of cement and three simulated SRP waste sludges. The interaction term, a, suggests that some reaction is occurring between cement and sludge when water is added. (33) From the data, there appears to be no reaction between 
TABLE 5. Parameters Calculated for Various CementSludge Combinations(33)

\begin{tabular}{|c|c|c|c|c|}
\hline \multirow{3}{*}{$\begin{array}{c}\text { Cement } \\
\text { Type } \\
\end{array}$} & \multirow{3}{*}{$\begin{array}{l}\text { Ws/S } \\
\text { Wc/C }\end{array}$} & \multicolumn{3}{|c|}{ SRP Simulated Sludge } \\
\hline & & & $\begin{array}{c}\text { I I } \\
0.341\end{array}$ & $\begin{array}{c}\text { I I I } \\
0.229\end{array}$ \\
\hline & & Int & on Coe & $n t, a$ \\
\hline I & 0.323 & 1.49 & 0.22 & 1.44 \\
\hline I I & 0.278 & 1.07 & 0.82 & 0.90 \\
\hline I I I & 0.303 & 1.21 & 0.43 & 1.18 \\
\hline V & 0.286 & 0.45 & 0.16 & 1.05 \\
\hline$I-P$ & 0.323 & 0.59 & 0.46 & 0.53 \\
\hline HAC & 0.257 & 0.22 & 0.00 & 0.60 \\
\hline
\end{tabular}


high-alumina cement and sludge II. The largest interaction occurs between type I portland cement and sludge I. The relative hydrophilic nature of the SRP sludges can be ordered:

sludge I > sludge II > sludge III

Tests with actual SRP sludges indicate that these sludges are also hydrophilic, with interaction coefficients ranging from 0.25 to 1.73 , depending on cement type and sludge type. ${ }^{(33)}$ Studies at $\mathrm{BNL}$ with $\mathrm{NaNO}_{3}$ waste and HAC have shown a constant $w / C$ of $\sim 0.22$, independent of $\mathrm{NaNO}_{3}$ concentration, indicating that $\mathrm{NaNO}_{3}$ is an inert additive. (44)

The addition of waste to cement/water mixtures has been shown to decrease set times. $(31,33,35)$ A "set" is reached when sufficient hydration has taken place to give a mix friable rigidity. The set time of neat portland type II cement $(w / c=0.26)$ has been measured at 2188 minutes; addition of $20 \mathrm{wt} \%$ simulated SRP sludge II reduces the set time to 8 minutes. (35) The substantial decrease of set time can partially be attributed to the heat of hydration of the sludge components, namely $\mathrm{Fe}(\mathrm{OH})_{3}$ and $\mathrm{Al}(\mathrm{OH})_{3}$. This is evidenced by an increase from 8 to 22 minutes when the sludge is mixed with water prior to mixing with cement. ${ }^{(35)}$ Different combinations of cement type and sludge type give rise to variations in set times. SRP simulated sludge III appears to have a greater accelerating effect on the set time of HAC composites than does sludge I. (35) The opposite effect occurs with type II portland cement, however.

Excessively short set times can cause a mixture to set before placing in the desired configuration. Set retarders can be used to increase set times by altering the rate of hydration while not affecting the nature of the hydration products. $(31,35)$ The set time of a mixture of $20 \mathrm{wt} \%$ SRP sludge I and type II portland cement increases from 8 to 150 minutes with the addition of $0.3 \%$ retarder by weight of cement. (35) Tests made with formulations of HAC plus $40 \mathrm{wt} \%$ simulated sludge show increasing retarder content (up to $2.3 \%$ by weight of cement) gives increasingly longer set times. (31) Addition of $1.5 \%$ retarder to mixtures of HAC and actual SRP sludges increases set times from $\sim 30$ minutes to $\sim 270$ minutes, which is believed to be adequate for large-scale operation. Excess water has also 
been shown to increase set times. (31) This method of increasing set times is undesirable because the resultant product has inferior strength. Increases in the water/cement ratio up to $\sim 0.7$ progressively increases set times; above 0.7 there appears to be no discernable effect. Set times of 30 to 100 minutes appear to be the maximum attainable in sludge/cement mixtures by the addition of excess water. (31)

On the other end of the spectrum are wastes which may tend to retard the setting of cements. Borate wastes and boric acid from radwaste treatment of PWR coolant can prevent cement pastes from setting if used in sufficient quantities. (12) The addition of lime to borate waste/cement pastes can improve the hydration and setting characteristics of these waste forms.

A necessary condition for the formation of concrete is the subsequent hydration and setting of cement pastes. The influence of waste additions on the hydration of HAC has been studied at SRL with a scanning electron microscope using a microhydration technique. (25) The principal features of HAC hydration are: 1) the precipitation of small spherules $\left(\mathrm{Al}_{2} \mathrm{O}_{3} \cdot \mathrm{nH}_{2} \mathrm{O}\right)$ both lying between and coating the cement particles, and 2) growth of hexagonal plates of calcium aluminate hydrates, both singly and in clusters. $(26)$ Studies with mixtures of HAC, sludges, and zeolite indicate that the preferential nucleation of $\mathrm{Al}_{2} \mathrm{O}_{3} \cdot \mathrm{nH}_{2} \mathrm{O}$ suggests that the surfaces of these materials can be ordered according to their effectiveness as nucleation catalysts: $(26)$ sludge > zeolite > HAC

Precipitation of $\mathrm{Al}_{2} \mathrm{O}_{3} \cdot \mathrm{nH}_{2} \mathrm{O}$ is initiated at respectively higher concentrations of $\mathrm{Al}^{3+}$ and $\mathrm{Ca}^{2+}$ ions in solution. When sludge is present $\mathrm{Al}^{3+}$ and $\mathrm{Ca}^{2+}$ ions are removed from solution before the concentration is high enough to precipitate onto another type of surface. In large volumes of cement/waste mixtures all kinds of particles would eventually be coated with $\mathrm{Al}_{2} \mathrm{O}_{3} \cdot \mathrm{nH}_{2} \mathrm{O}$, with hydration products growing in between. This mechanism may explain the fast set resulting from sludge additions. A layer of $\mathrm{Al}_{2} \mathrm{O}_{3} \cdot \mathrm{nH}_{2} \mathrm{O}$ precipitate is quickly formed around the sludge particles from which interlocking hydrate crystals grow. 
During the curing of cement pastes, an exotherm occurs as a result of the hydration reactions. The total heat evolved during hydration of HAC is similar to that of portland cements, but this heat is evolved at a faster rate. (36) Excessive temperature gradients could develop in large diameter castings of HAC since heat flow is predominantly along the radial direction. The measured centerline temperatures of 12-inch diameter castings of $\mathrm{HAC}$ are reported to be $144^{\circ} \mathrm{C}^{(36)}$ to $152^{\circ} \mathrm{C}(28)$ above ambient temperature. Most of the temperature increase occurs in 20 minutes with the peak occurring 12 hours after casting. The hydration reaction may be autocatalytic (i.e., the exotherm accelerates subsequent hydration), al though above $100^{\circ} \mathrm{C}$ some steady-state moderation may occur due to evaporation of some available hydration water. (36) A 12-inch diameter casting of type II portland cement demonstrates a much more gradual rate of temperature increase resulting in a maximum centerline temperature of $97^{\circ} \mathrm{C} .(36)$

The addition of sludge decreases set times and causes a decrease in centerline temperature and rate of temperature rise. The centerline temperature in a 3 -inch diameter casting of HAC plus 30 wt\% simulated SRP sludge III reaches a maximum of $265^{\circ} \mathrm{C}$, compared to $2125^{\circ} \mathrm{C}$ for neat $\mathrm{HAC} .{ }^{(28,36)}$ The rate of temperature rise for pure $\mathrm{HAC}$ is $\sim 120^{\circ} \mathrm{C} / \mathrm{hr}$ but decreases to $223^{\circ} \mathrm{C} / \mathrm{hr}$ with $30 \mathrm{wt} \%$ sludge III additions. Engineering calculations estimate that the centerline temperature of a 24-inch diameter casting of HAC plus 30 wt\% sludge would be $2185^{\circ} \mathrm{C}$; the heat generation of the waste sludge is assumed to be 2.1 watts per gallon of composite. $(28)$

The water/cement ratio of neat type II and III portland cement castings also affects hydration and resultant centerline temperatures. (54) Centerline temperatures reported for 6.4-inch diameter castings of type II portiand cement are $50^{\circ}$ and $55^{\circ} \mathrm{C}$ for $\mathrm{w} / \mathrm{C}$ ratios of 0.18 and 0.25 , respectively. Similarly, centerline temperatures of type III cement castings are $95^{\circ}$ and $120^{\circ} \mathrm{C}$. As the water/cement ratio approaches its theoretical value curing is delayed but the extent of hydration increases. Temperatures are believed to be lower when $\mathrm{w} / \mathrm{c}$ is greater than required because of an increase in the heat capacity of the mix. (54) 
Additions of various aggregates has also been shown to decrease center1ine temperatures. $(36,54)$ When sand is used as an aggregate with HAC temperature gradients produced by the curing exotherm decrease from $89^{\circ} \mathrm{C}$ with no sand to $41^{\circ}, 23^{\circ}$, and $4^{\circ} \mathrm{C}$ with additions of 25,50 and $78 \mathrm{wt} \%$ sand, respectively. (36) The rate of temperature increase is also lowered by sand additions and may be attributed to increases in thermal conductivity and heat capacity. Incorporation of $20 \mathrm{wt} \%$ fly-ash to type III portland cement reduces center 1 ine temperatures by $46 \%$ in 6.5 -inch diameter castings. ( ${ }^{4}$ ) As previously mentioned, boric acid tends to retard hydration rates; it also decreases the rate of heat release and the total heat liberated during the curing of type III portland cement. ${ }^{(54)}$ Calcium hydroxide has the opposite effect on curing exotherms when used with boric acid. Commercial chemical retarders have no significant effect on temperature, however. (36)

\section{COMPRESSIVE STRENGTH}

Compressive strength of concrete waste forms is an important parameter in safety and accident evaluations. The composite must exhibit sufficient strength to withstand handing, transportation, and possible accident situations without major damage. Normally, neat cement pastes have compressive strengths on the order of 10000 psi. ${ }^{(33)}$ Table 6 lists some reported compressive strength values of various neat cement pastes. The wide range of values reported for high-alumina cement may be attributed to differences in water/cement ratios, ${ }^{(33)}$ curing time, ${ }^{(23)}$ curing conditions, ${ }^{(27)}$ and/or temperature, ${ }^{(33)}$ each of which have been shown to affect strength. Port1 and cements generally develop $290 \%$ of ultimate strength after 28 days while high-alumina cements develop a large fraction after only 3 days. (33)

The addition of simulated waste sludges to cement mixes has been shown to greatly reduce compressive strength. $(22,23,24,27,32,33,35)$ The amount of sludge in the composite appears to be the dominant factor affecting strength. Table 7 lists some typical values for compressive strength of composites consisting of simulated SRP sludges incorporated in six types of cement. As evidenced by the data compressive strength decreases with increasing sludge content for all cement and sludge types. The decreases 
TABLE 6. Compressive Strengths of Neat Cement Pastes

\begin{tabular}{lc} 
Cement Type & Compressive Strength (psi) \\
\hline Portland I & $10824^{(33)}$ \\
Portland II & $11284^{(33)}$ \\
& $12300^{(44)}$ \\
& $13478^{(33)}$ \\
Portland III & $14300^{(24)}$ \\
& $11898^{(33)}$ \\
Portland V & $11916^{(33)}$ \\
I-P & $9311^{(33)}$ \\
HAC & $12500^{(35)}$ \\
& $13200^{(44)}$ \\
$6900^{(32)}$ & $7900^{(24)}$ \\
& $11100^{(23)}$ \\
$15600^{(23)}$
\end{tabular}


IABLE 7. Compressive Strength of Concrete Waste Forms ${ }^{(33)}$

\begin{tabular}{|c|c|c|c|c|c|c|c|}
\hline \multicolumn{2}{|c|}{$\begin{array}{l}\text { SRP Simulated } \\
\text { Sludge }\end{array}$} & \multicolumn{6}{|c|}{ Compressive Strength ( $p s i$ ) } \\
\hline \multirow[t]{3}{*}{ Type } & \multirow[t]{2}{*}{$\underline{W t} \%$} & \multicolumn{6}{|c|}{ Cement Types } \\
\hline & & $\mathrm{I}$ & I I & I I I & $\bar{v}$ & $\mathrm{I}-\mathrm{P}$ & $\mathrm{HAC}$ \\
\hline & 0 & 10824 & 11284 & 13478 & 11898 & 11916 & 9311 \\
\hline \multirow[t]{3}{*}{ I } & 10 & 8402 & 8243 & 8694 & 8829 & 8296 & 9574 \\
\hline & 25 & 4588 & 4630 & 6180 & 5620 & 4472 & 5792 \\
\hline & 40 & 464 & 1259 & 1546 & 3054 & 2380 & 4363 \\
\hline \multirow[t]{3}{*}{ I I } & 10 & 8973 & 9045 & 9321 & 11159 & 7692 & 9624 \\
\hline & 25 & 5779 & 6412 & 7230 & 7158 & 5855 & 7158 \\
\hline & 40 & 3932 & 3352 & 4736 & 4234 & 3311 & 5884 \\
\hline \multirow[t]{3}{*}{ I I I } & 10 & 9313 & 7557 & 7603 & 8490 & 7761 & 8465 \\
\hline & 25 & 5171 & 4627 & 5817 & 4732 & 4930 & 6658 \\
\hline & 40 & 2388 & 2884 & 3317 & 2700 & 3088 & $\begin{array}{ll}3 & 371\end{array}$ \\
\hline
\end{tabular}


are believed to be mostly due to lack of strength of the sludge particles. (33) Since the cement matrix provides nearly all the strength of the concrete, increasing sludge content decreases the load-bearing area of the hydrated cement particles. Fractography indicates that fracture originates at the surface of the sludge particles; this implies that the irregular interface between agglomerates and the cement matrix act as a stress concentrator. (22) The compressive strengh of HAC decreases $~ 250 \%$ by incorporation of $40 \mathrm{wt} \%$ unsieved sludge I and III, and decreases $\sim 70 \%$ with sludge powders 1 ess than 45 microns (-325 mesh). (24) A 90\% strength reduction is evidenced in type III portland cement with 40 wt\% sludge powder, independent of particle size. The decrease in strength of HAC with decreasing particle size may be due to chemical reactions of HAC components with the waste particles. Figures 1-3 graphically depict sludge compositional dependency on compressive strength of HAC and I-P composites.

The effects of irradiation, temperature, and saturated steam on the curing of high-alumina cement have been studied at SRL. $(23,24,27)$ Neat HAC pastes receiving gamma radiation exposures of $6 \times 10^{5}$ rads/hr during curing at $25^{\circ} \mathrm{C}$ exhibit compressive strengths $\sim 40 \%$ lower than unirradiated, normally cured samples. ${ }^{(23)}$ Similar pastes irradiated during curing at $63^{\circ} \mathrm{C}$ exhibit $60 \%$ less compressive strength than the control. The decrease in compressive strength of neat $H A C$ above $38^{\circ} \mathrm{C}$ is believed to be caused by conversion of the metastable phases normally found at room temperature (various hydrated calcium aluminates) to the stable, but weaker cubic hydrate. $(23)$ Tests with composites consisting of HAC plus 25 wt\% simulated SRP sludge I and III, cured in ${ }^{60} \mathrm{Co}$ radiation at $250^{\circ} \mathrm{C}$ at a dose rate of $6 \times 10^{5} \mathrm{rads} / \mathrm{hr}$, indicate that heat and irradiation during curing have no significant effect on strength.

The effect of curing HAC concretes in saturated steam at elevated temperatures was tested by autoclaving $\mathrm{HAC}$ pastes at $180^{\circ} \mathrm{C}$ with and without simulated SRP sludge I. (27) This study shows that steam-cured HAC with no sludge exhibits compressive strengths that are $260 \%$ lower than those of normally cured formulations. Pastes of HAC plus $25 \mathrm{wt} \%$ sludge exhibit 


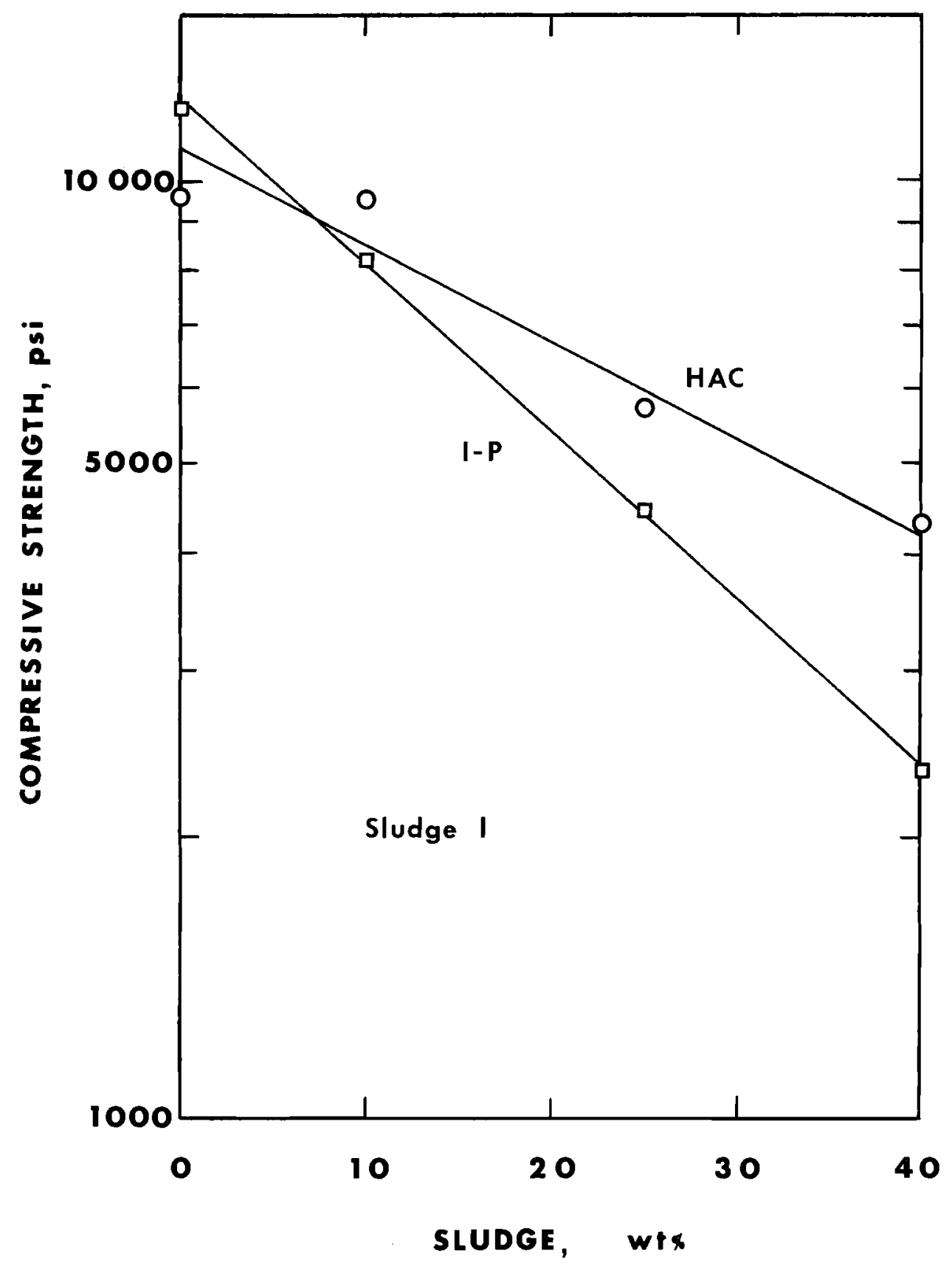

FIGURE 1. Compressive Strength of Concrete Waste Forms Containing Simulated SRP Sludge I 


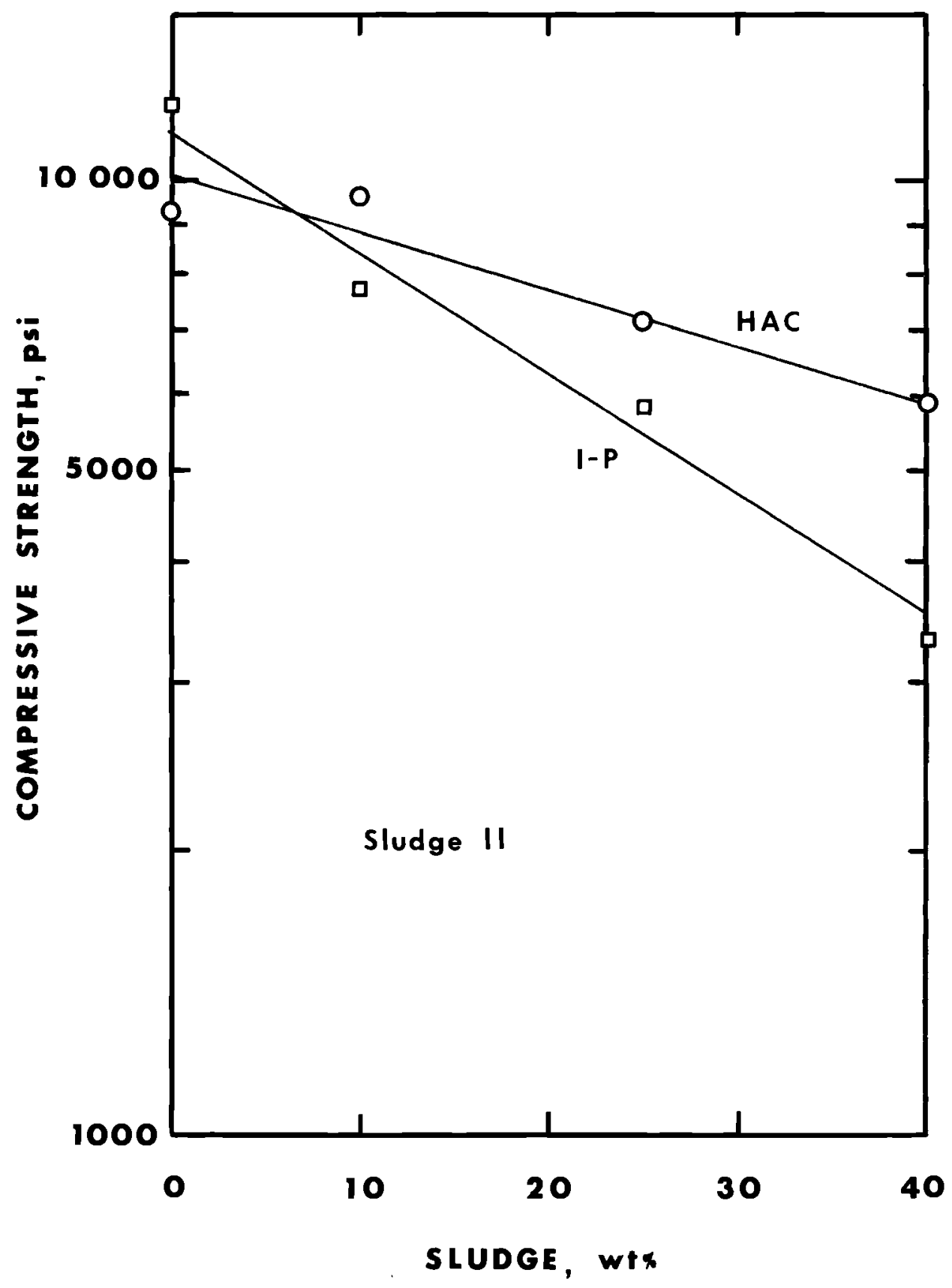

FIGURE 2. Compressive Strength of Concrete Waste Forms Containing Simulated SRP Sludge II 


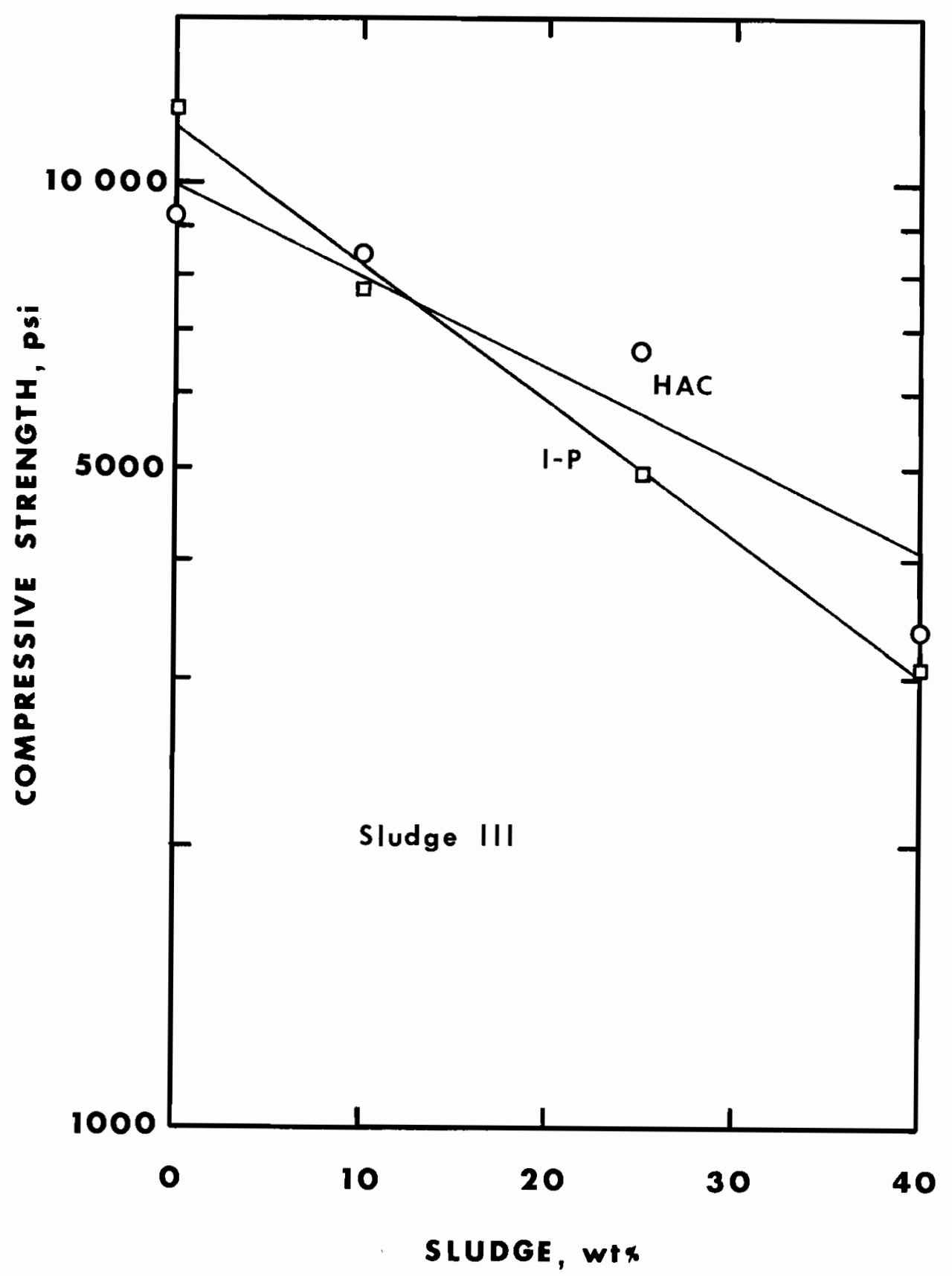

FIGURE 3. Compressive Strength of Concrete Waste Forms Containing Simulated SRP Sludge III 
compressive strengths that are nearly the same ( $25500 \mathrm{psi}$ ) for steam-cured and normally cured samples. This is consistent with the effects of temperature and gamma irradiation. $(23,24)$

Several studies have been conducted to determine the effect of prolonged heating and elevated temperatures on the compressive strength of cement/waste composites. $(33,35,52)$ Heating of neat portland cement paste causes an initial strength increase, followed by a general loss of strength ( $80 \%$ ) at temperatures greater than $300^{\circ} \mathrm{C} .{ }^{(52)}$ The critical strength extends over a broad temperature range and eventually increases again due to sintering or ceramic bonding at higher temperatures. Calcium aluminate hydrates in HAC lose their strength at temperatures from $100-1000^{\circ} \mathrm{C}$ with a minimum around $900^{\circ} \mathrm{C}$. Heating of concrete waste forms of HAC and type I-P cements containing simulated SRP sludge at $100^{\circ} \mathrm{C}$ for 1 and 3 months results in weight losses of $6-16 \%$ and reductions in compressive strength of most formulations. $(33,35)$ Table 8 shows the effect of heating on the compressive strength of composites of HAC and type I-P cements with simulated SRP sludges. Typically, the strength of a specimen heated for 3 months at $100^{\circ} \mathrm{C}$ is $\sim 25 \%$ lower than the unheated sample of the same formulation. (33)

The effect of gamma irradiation on the compressive strength of various concrete waste forms has also been investigated. $(33,37,45)$ Concrete specimens containing simulated SRP sludge specimens were irradiated in ${ }^{60}$ Co $\gamma$-radiation at a dose rate of $3.5 \times 10^{7} \mathrm{rads} / \mathrm{hr}$ to a total dose of $10^{10}$ rads. (33) The samples were cooled by forced air to $65-95^{\circ} \mathrm{C}$. The results of this study indicate that compressive strength decreases slightly after irradiation; the severity, however, decreases with increasing sludge content. Since the samples were heated during irradiation, the decreases cannot be attributed to radiation alone. Another study has shown that compressive strength of composites containing 28.5 wt\% HAC, 2.3 wt\% zeolite, 37.0 wt\% sludge III, and $32 \mathrm{wt} \%$ water decreases from 860 to 756 and 725 psi after $\gamma$-irradiation to $10^{9}$ and $10^{10}$ rads, respectively, both at a dose rate of $9 \times 10^{6} \mathrm{rads} / \mathrm{hr}$. Concrete waste forms of HAC and type II portland cements with $\mathrm{NaNO}_{3}$ were irradiated to $10^{9}$ rads at $4.4 \times 10^{6} \mathrm{rads} / \mathrm{hr}$ in air at $68^{\circ} \mathrm{C}$. ${ }^{(44)}$ Compressive 
strengths of HAC formulations demonstrate no significant dependency on $\mathrm{NaNO}_{3}$ concentration and are relatively unaffected by irradiation. Compressive strengths of formulations of type II portland cement decrease from 12300 psi with no additions to 8000 psi with $30 \mathrm{wt} \% \mathrm{NaNO}_{3}$; irradiated sample strength is not significantly different than unirradiated strength. Cement $/ \mathrm{Al}_{2} \mathrm{O}_{3}$ calcine waste forms, irradiated to $10^{10}$ rads at $4.2 \times 10^{6}$ $\mathrm{rads} / \mathrm{hr}$, exhibit decreases in compressive strength of $216 \%$.

Addition of sorbents, used for cesium fixation, has also been shown to decrease compressive strength of concretes. (32) Strength values decrease from 6900 psi with no sorbent to 5400 to 1000 psi with $10 \%$ additions of zeolite and vermiculite, respectively. As previously noted, strength decreases with increasing sludge content, however; composites with 30 wt\% simulated sludge plus 10 wt\% sorbent show increases of up to $\imath 75 \%$ over similar formulations with no sorbent. Strength is also reduced through additions of other materials. Increasing percentages of bentonite, calcium chloride, and sodium silicate progressively decrease the compressive strength of $\mathrm{HAC} / \mathrm{Zr}-2 \mathrm{nd}$ cycle calcine composites. (47)

Compressive strength is a measure of the stress required to fracture or plasticly deform a material. Since no correlation of strength and safety has been developed, workers at SRL have conducted impact tests on solid waste forms. $(29,30)$ In the tests samples are broken by impact of known energy and the particle size distribution of the sample is determined after impact. The results of this type of test are considered important because the creation of a large number of small particles increases surface area and the potential for leaching. The surface area, $A$, created by impact by energy input, $E$, may be a useful parameter in defining the safety of solid waste forms. Typical values of $A / E$ for various waste forms are given in Table 9. The particle size distribution resulting from impact is also an important consideration because the production of excessively small particles increases the potential for creating an airborne hazard. 
TABLE 8. Typical Compressive Strengths of Concrete Waste Forms with $40 \%$ Simulated SRP Sludge Heated at $100^{\circ} \mathrm{C}(33)$

\begin{tabular}{ccccc}
$\begin{array}{c}\text { Cement } \\
\text { Type }\end{array}$ & $\begin{array}{c}\text { Heating } \\
\text { Time, } \\
\text { Months }\end{array}$ & & \multicolumn{3}{c}{$\begin{array}{c}\text { Compressive Strength, psi } \\
\text { for Sludge Types }\end{array}$} \\
\cline { 2 - 6 } HAC & 0 & $\underline{I}$ & $\underline{\text { II }}$ & $\underline{\text { III }}$ \\
& 1 & 4364 & 5884 & 3371 \\
& 3 & 2433 & 4359 & 2838 \\
I-P & 0 & 3313 & 3948 & 2546 \\
& 1 & 2380 & 3311 & 3088 \\
& 3 & 1865 & 2228 & 2639 \\
& 3 & 1980 & 2779 & 2534
\end{tabular}

TABLE 9. Relative Impact Resistance of Various Waste Forms (30)

$\begin{array}{lc}\text { Waste Form } & \begin{array}{c}\text { Surface Area } \\ \text { Increase Per } \\ \text { Joule Input* }\end{array} \\ \text { Glass with } 45 \% \text { Sludge } & \frac{A / E, \mathrm{~cm}^{2} / \mathrm{J}}{2.5} \\ \text { Neat HAC } & 9.3 \\ \text { Neat I-P } & 10.3 \\ \text { HAC + 40\% Sludge } & 28.9 \\ \text { I-P + 40\% Sludge } & 19.4 \\ \text { Portland II }+40 \% \text { Sludge } & 25.3\end{array}$

*8 kg-m input for glass; $9.6 \mathrm{~kg}-\mathrm{m}$ input for concrete forms. 


\section{LEACHABILITY}

Leachability is considered a very important parameter in the safety evaluation of radioactive waste forms. Under normal conditions the waste forms would be contained within sealed containers void of any water. Leachability becomes a concern under postulated accident situations where the container is breached and water is allowed to come in direct contact with the waste form. The lower the leachability, the greater the safety by allowing more time to recover and take action on the exposed waste in the event of an accident. Leachability, expressed in $\mathrm{g} / \mathrm{cm}^{2} \cdot d$, may be defined by:

$$
L=\frac{1}{F A} \frac{\Delta m}{\Delta t}
$$

where,

$$
\begin{aligned}
F & =\text { weight fraction of species in the leach specimen } \\
A & =\text { surface area of the leach specimen } \\
\Delta \mathrm{m} & =\text { mass of species leached during time } \Delta t \\
\Delta t & =\text { time interval between changes of leachant }
\end{aligned}
$$

Cesium, strontium, and alpha emitters are the species of greatest concern in radioactive waste solidification and have received the largest attention concerning their leachability. Another species in cement/waste composites that has been leach tested is sodium nitrate.

\section{Strontium Leachability}

Numerous studies have been conducted on strontium leachability from concrete waste forms containing SRP sludges. $(22,25,33,34,35)$ The results indicate that leachability varies with type of cement, type and amount of sludge, and is a strong function of time, decreasing by factors of 10 to 200 over a 6-week leaching period. ${ }^{(33)}$ Individual leach tests with simulated SRP sludge I and III and with HAC and type II portland cements indicate that leachability from sludge III composites is lower than from sludge I or II 
composites. $(22,33,35)$ Leachability decreases as sludge III content increases; the opposite effect occurs for sludges I and II. After six weeks, leachability of strontium from concretes with $40 \mathrm{wt} \%$ sludge III is $1 / 15$ that of formulations with no sludge. (22) The decrease can be attributed to the $\mathrm{MnO}_{2}$ content of the sludge which can sorb strontium (See Table 10). Highalumina cement has consistantly lower strontium leachabilities than does portland cements, particularly at high sludge concentrations and long leach times. Portland cements react with water to form leachable $\mathrm{Ca}(\mathrm{OH})_{3}$ which is expected to carry strontium. (22) $\mathrm{HAC}$ forms $\mathrm{Al}_{(\mathrm{OH})_{3}}$ in the presence of water; this has less affinity for strontium. Leach tests performed on concrete samples containing actual SRP sludges indicate the leaching behavior of ${ }^{90} \mathrm{Sr}$ is generally similar to natural strontium in simulated sludges; however, the magnitudes are lower by factors of 10 to 100 for ${ }^{90} \mathrm{Sr}$ compared with natural strontium. (33) Because the magnitude of ${ }^{90} \mathrm{Sr}$ leachability is smaller, the fraction of ${ }^{90} \mathrm{Sr}$ is much smaller - 0.004 to $0.9 \%$ compared with 5 to $10 \%$ for natural strontium. These differences can be attributed to the natural strontium content of the cements. $(33,35)$

Other factors that may affect leachability include curing time, (14) irradiation, (33) prolonged exposure to high temperature, ${ }^{(33)}$ and leachant renewal frequency. (14) Long curing times, up to 28 days, have been shown to result in less cumulative fraction leached; curing times greater than 28 days have no significant effect on leachability. (14) The leachability for a11 SRP sludge types is generally lower after irradiation to $10^{10}$ rads. After 42 days of leaching the leachability of sludge I samples is 20 times lower than unirradiated samples. (33) Concrete waste forms containing SRP waste sludge, heated for one month at $400^{\circ} \mathrm{C}$, demonstrated increases in ${ }^{90} \mathrm{Sr}$ leachability by as much as 500 times. (33) Studies have shown the cumulative fraction leached increases as the leachant renewal frequency increases. (14) This behavior suggests that the data are being influenced by the concentration of the species in the leachant and/or possible surface concentration effects.

Leach tests with Hanford simulated Purex sludge concrete specimens revealed slightly higher values of leachability with $40 \%$ sludge than with $30 \%$ sludge content. (42) No apparent relationship between leachability and cement type was observed. 
TABLE 10. Reported Strontium Leach Data for Various

Concrete Waste Forms

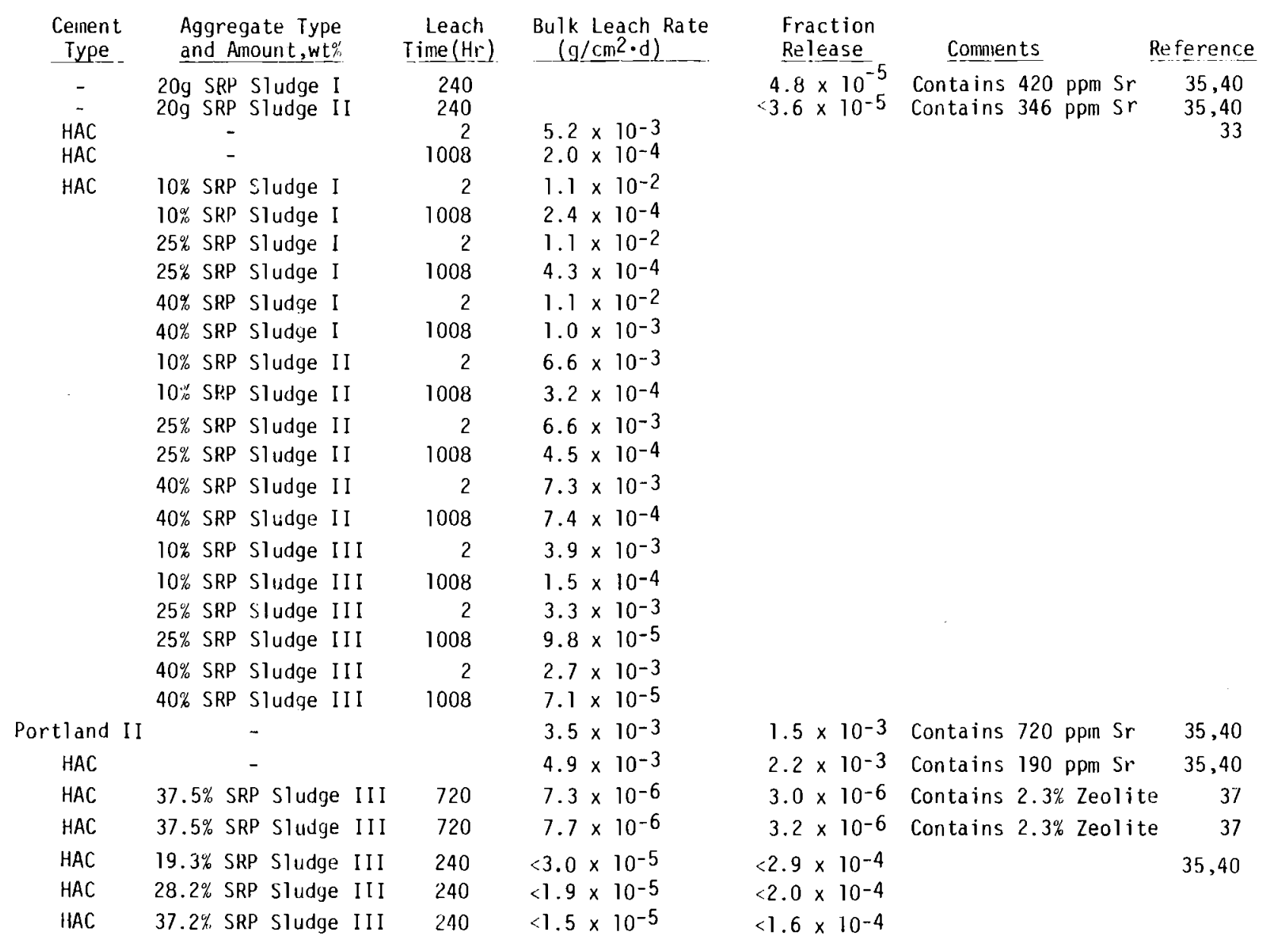


TABLE 10. (cont.)

\begin{tabular}{|c|c|c|c|}
\hline $\begin{array}{l}\text { Cement } \\
\text { Type. }\end{array}$ & $\begin{array}{l}\text { Aggregate Type } \\
\text { and Amount, wt } \%\end{array}$ & $\begin{array}{l}\text { Leach } \\
\text { Time (Hr) }\end{array}$ & $\begin{array}{l}\text { Bulk Leach Rate } \\
\left(\mathrm{g} / \mathrm{cm}^{2} \mathrm{~d}\right)\end{array}$ \\
\hline HAC & $46.2 \%$ SRP Sludge III & 240 & $<1.1 \times 10^{-5}$ \\
\hline Portland II & $20.0 \%$ SRP Sludge III & 240 & $4.5 \times 10^{-4}$ \\
\hline Portland II & $30.0 \%$ SRP Sludge II I & 240 & $1.3 \times 10^{-4}$ \\
\hline Portland II & $40.0 \%$ SRP Sludge III & 240 & $<5.0 \times 10^{-5}$ \\
\hline Portland II & $50.0 \%$ SRP Sludge III & 240 & $<1.3 \times 10^{-5}$ \\
\hline HAC & $37.0 \%$ SRP Sludge II I & 720 & $7.3 \times 10^{-6}$ \\
\hline HAC & $10 \%$ SRP Tank 5 Sludge & 1008 & $1.5 \times 10^{-6}$ \\
\hline HAC & $40 \%$ SRP Tank 5 Sludge & 1008 & $9.1 \times 10^{-8}$ \\
\hline HAC & $10 \%$ SRP Tank 13 Sludge & 1008 & $8.7 \times 10^{-6}$ \\
\hline HAC & $40 \%$ SRP Tank 13 Sludge & 1008 & $5.0 \times 10^{-6}$ \\
\hline HAC. & 10\% SRP Tank 15 Sludge & 1008 & $1.5 \times 10^{-5}$ \\
\hline HAC & $40 \%$ SRP Tank 15 Sludge & 1008 & $2.0 \times 10^{-5}$ \\
\hline$I-P$ & 10\% SRP Tank 5 Sludge & 1008 & $1.7 \times 10^{-6}$ \\
\hline$I-P$ & $40 \%$ SRP Tank 5 Sludge & 1008 & $1.4 \times 10^{-7}$ \\
\hline$I-P$ & 10\% SRP Tank 13 Sludge & 1008 & $7.1 \times 10^{-6}$ \\
\hline$I-P$ & $40 \%$ SRP Tank 13 Sludge & 1008 & $6.9 \times 10^{-7}$ \\
\hline$I-P$ & 10\% SRP Tank 15 Sludige & 1008 & $1.1 \times 10^{-5}$ \\
\hline$I-P$ & $40 \%$ SRP Tank 15 Sludge & 1008 & $3.2 \times 10^{-5}$ \\
\hline HAC & $10 \%$ SRP Tank 13 Sludge & 1008 & $2.2 \times 10^{-3}$ \\
\hline HAC & 25\% SRP Tank 13 Sludge & 1008 & $1.7 \times 10^{-3}$ \\
\hline HAC & $40 \%$ SRP Tank 13 Sludge & 1008 & $2.4 \times 10^{-3}$ \\
\hline HAC & 40\% SRP Tank 5 Sludge & 1008 & $1.3 \times 10^{-3}$ \\
\hline HAC & $40 \%$ SRP Tank 15 Sludge & 1008 & $3.0 \times 10^{-3}$ \\
\hline$I-P$ & $40 \%$ SRP Tank 5 Sludge & 1008 & $4.2 \times 10^{-4}$ \\
\hline$I-P$ & $40 \%$ SRP Tank 13 Sludge & 1008 & $8.3 \times 10^{-4}$ \\
\hline$I-P$ & 40\% SRP Tank 15 Sludge & 1008 & $1.8 \times 10^{-4}$ \\
\hline
\end{tabular}

Fraction

Release

$<1.2 \times 10^{-4}$

$4.3 \times 10^{-3}$

$1.3 \times 10^{-3}$

$<5.3 \times 10^{-4}$

$<1.4 \times 10^{-4}$

$8.8 \times 10^{-2}$ Contains $2.3 \%$ Zeolite

$1.9 \times 10^{-4}$

$4.0 \times 10^{-5}$

$9.0 \times 10^{-4}$

$8.1 \times 10^{-4}$

$1.9 \times 10^{-3}$

$3.4 \times 10^{-3}$

$3.3 \times 10^{-4}$

$9.0 \times 10^{-5}$

$1.7 \times 10^{-3}$

$9.6 \times 10^{-4}$

$3.0 \times 10^{-3}$

$8.7 \times 10^{-3}$

Heated 30 days at $400^{\circ} \mathrm{C}$

Comments $\quad$ Reference 
Cesium Leachability

Some typical values reported for leachability and fraction release of cesium from concrete waste forms are shown in Table 11. Leachability of cesium is generally greater than that of strontium from similar waste forms. These differences may be partially explained by the results of leach studies with mixtures of portland type I cement and radioactive liquid solutions that indicate that leachability is lower for divalent species (Co, Cd, Sr) than for monovalent species ( $\mathrm{Na}, \mathrm{Cs}) .{ }^{(6)}$ Cesium leachability values for concrete waste forms containing cesium-loaded zeolite are reported to be strongly time dependent, approximately following a $t^{-1 / 2}$ law, which suggests that cesium release from the composite is diffusion controlled. (33) The leachability of specimens containing only zeolite is 10 to 400 times lower than for samples containing $37.5 \%$ SRP sludge II plus $2.5 \%$ Cs-1oaded zeolite. Cesium leachability is also lower for concrete waste forms with near theoretical water/cement ratios than for mixtures with excess water and/or chemical additives such as boric acid.

Most of the leach studies reported use stagnant, deionized or distilled water as leaching medium. The rate-determining step of leaching under static conditions is the external diffusion of the species through the interface layer between the solid waste form and the liquid. Under these conditions temperature and species concentration in the water are expected to affect the overall leach rate. The leaching behavior of ${ }^{137} \mathrm{Cs}$ has also been studied under non-static conditions to evaluate safety of sea and ground disposal of cement composites. ${ }^{(64)}$ The rate controlling step of leaching under dynamic conditions is the internal diffusion of the species through the cement matrix. Drastic increases in specimen surface area generaliy increase leach rates; this was the basis of a study on the leaching of ${ }^{137} \mathrm{Cs}$ from the crushed state of concrete waste forms. ${ }^{(64)}$ Leach rates were measured under both static and dynamic conditions to ascertain the effect of agitation on leaching kinetics. The waste form investigated consisted of an aqueous solution of 10-20 wt\% sodium sulfate with $21-2.5 \mu \mathrm{Ci} / \mathrm{g}$ ${ }^{137} \mathrm{Cs}$, simulating evaporator concentrates produced in BWR's. Results indicate that the fraction of ${ }^{137} \mathrm{Cs}$ released from portland cement composites increases with decreasing particle size - from 0.53 to 0.75 for average 
TABLE 11. Reported Cesium Leach Data for Various

Concrete Waste Forms

\begin{tabular}{|c|c|c|c|}
\hline $\begin{array}{l}\text { Cement } \\
\text { Type }\end{array}$ & $\begin{array}{l}\text { Aggrega te Type } \\
\text { and Amount, wt\% }\end{array}$ & $\begin{array}{l}\text { Leach } \\
\text { Time } \\
\text { (hr) }\end{array}$ & $\begin{array}{l}\text { Bulk } \\
\text { Leach Rate } \\
\left(\mathrm{g} / \mathrm{cm}^{2} \cdot \mathrm{d}\right)\end{array}$ \\
\hline HAC & $2.5 \%$ Zeolite & 240 & $1.40 \times 10^{-4}$ \\
\hline HAC & $7.4 \%$ Zeolite & 240 & $1.09 \times 10^{-4}$ \\
\hline HAC & $11.3 \%$ Zeolite & 240 & $8.59 \times 10^{-4}$ \\
\hline HAC & 15.3z Zeolite & 240 & $7.13 \times 10^{-5}$ \\
\hline HAC & 15.3\% Zeolite & 744 & $5.33 \times 10^{-5}$ \\
\hline HAC & $10 \%$ Cs-loaded Zeolite & 1008 & $5.10 \times 10^{-5}$ \\
\hline HAC & $25 \%$ Cs-loaded Zeolite & 1008 & $2.30 \times 10^{-5}$ \\
\hline HAC & $40 \%$ Cs-loaded Zeolite & 1008 & $1.10 \times 10^{-5}$ \\
\hline$I-P$ & 10\% Cs-loaded Zeolite & 1008 & $1.70 \times 10^{-4}$ \\
\hline$I-P$ & $25 \%$ Cs-loaded Zeolite & 1008 & $5.90 \times 10^{-5}$ \\
\hline$I-P$ & $40 \%$ Cs-loaded Zeolite & 1008 & $3.10 \times 10^{-6}$ \\
\hline \multirow[t]{6}{*}{ HAC } & $37.5 \%$ SRP Sludge I & 2 & $2.60 \times 10^{-2}$ \\
\hline & $37.5 \%$ SRP Sludge II & 2 & $1.10 \times 10^{-2}$ \\
\hline & $37.5 \%$ SRP Sludge III & 2 & $4.20 \times 10^{-2}$ \\
\hline & $37.5 \%$ SRP Sludge I & 1008 & $4.40 \times 10^{-4}$ \\
\hline & $37.5 \%$ SRP Sludge II & 1008 & $5.30 \times 10^{-4}$ \\
\hline & $37.5 \%$ SRP Sludge II I & 1008 & $1.10 \times 10^{-3}$ \\
\hline \multirow[t]{6}{*}{ I-P } & $37.5 \%$ SRP Sludge I & 2 & $5.40 \times 10^{-2}$ \\
\hline & $37.5 \%$ SRP Sludge II & 2 & $4.00 \times 10^{-2}$ \\
\hline & $37.5 \%$ SRP Sludge III & 2 & $6.70 \times 10^{-2}$ \\
\hline & 37.5\% SRP Sludge I & 1008 & $1.10 \times 10^{-3}$ \\
\hline & $37.5 \%$ SRP Sludge II & 1008 & $1.60 \times 10^{-3}$ \\
\hline & $37.5 \%$ SRP Sludge III & 1008 & $1.50 \times 10^{-3}$ \\
\hline HAC & $37.0 \%$ SRP Sludge III & 720 & $3.90 \times 10^{-3}$ \\
\hline ? & 8. 3\% SRP Sludge III & 240 & $3.50 \times 10^{-4}$ \\
\hline ? & $8.3 \%$ SRP sludge III & 240 & $<1.60 \times 10^{-4}$ \\
\hline
\end{tabular}

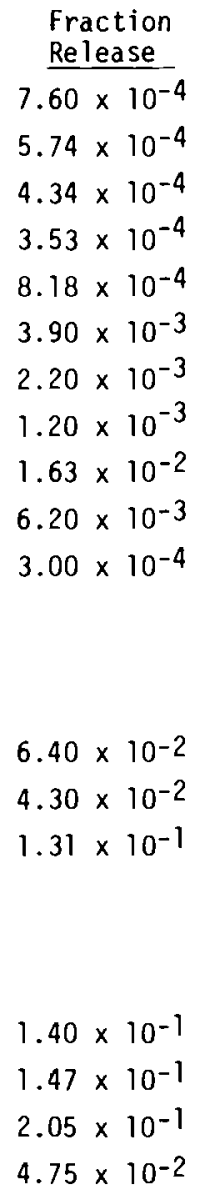

Reference

40 
TABLE 11. (cont.)

\begin{tabular}{|c|c|c|c|c|c|c|}
\hline $\begin{array}{l}\text { Cement } \\
\text { Type }\end{array}$ & $\begin{array}{l}\text { Aggregate Type } \\
\text { and Amount,wt\% }\end{array}$ & $\begin{array}{l}\text { Leach } \\
\text { Time } \\
\text { (hr) }\end{array}$ & $\begin{array}{l}\text { Bulk } \\
\text { Leach Rate } \\
\left(\mathrm{g} / \mathrm{cm}^{2} \cdot \mathrm{d}\right)\end{array}$ & $\begin{array}{l}\text { Fraction } \\
\text { Release }\end{array}$ & Conments & Reference \\
\hline \multirow[t]{6}{*}{ HAC } & $10 \%$ SRP Tank 5 Sludge & 1008 & $6.50 \times 10^{-4}$ & $5.60 \times 10^{-2}$ & & 33 \\
\hline & $10 \%$ SRP Tank 13 Sludge & 1008 & $3.00 \times 10^{-3}$ & $2.66 \times 10^{-1}$ & & \\
\hline & 10\% SRP Tank 15 Sludge & 1008 & $4.10 \times 10^{-3}$ & $5.19 \times 10^{-1}$ & & \\
\hline & $40 \%$ SRP Tank 5 Sludge & 1008 & $1.00 \times 10^{-3}$ & $9.50 \times 10^{-2}$ & & \\
\hline & $40 \%$ SRP Tank 13 Sludge & 1008 & $1.60 \times 10^{-3}$ & $5.22 \times 10^{-1}$ & & \\
\hline & $40 \%$ SRP Tank 15 Sludge & 1008 & $3.30 \times 10^{-4}$ & $4.30 \times 10^{-2}$ & & \\
\hline \multirow[t]{6}{*}{$I-P$} & $10 \%$ SRP Tank 5 Sludge & 1008 & $4.80 \times 10^{-4}$ & $1.15 \times 10^{-1}$ & & \\
\hline & $10_{\%}^{\%}$ SRP Tank 13 Sludge & 1008 & $9.60 \times 10^{-4}$ & $2.15 \times 10^{-1}$ & & \\
\hline & $10 \%$ SRP Tank 15 Sludge & 1008 & $1.60 \times 10^{-3}$ & $4.47 \times 10^{-1}$ & & \\
\hline & $40 \%$ SRP Tank 5 Sludge & 1008 & $6.30 \times 10^{-4}$ & $1.57 \times 10^{-1}$ & & \\
\hline & $40 \%$ SRP Tank 13 Sludge & 1008 & $1.80 \times 10^{-3}$ & $4.63 \times 10^{-1}$ & & \\
\hline & $40 \%$ SRP Tank 15 Sludge & 1008 & $5.60 \times 10^{-4}$ & $9.20 \times 10^{-2}$ & & \\
\hline \multirow[t]{7}{*}{ HAC } & $2 \%$ AW- 500 & 672 & & $5.70 \times 10^{-2}$ & & 32 \\
\hline & $2 \% z-900$ & 672 & & $6.00 \times 10^{-2}$ & & \\
\hline & $2 \%$ Vermiculite & 672 & & $6.30 \times 10^{-2}$ & & \\
\hline & $2 \% \mathrm{Z}-500$ & 672 & & $6.50 \times 10^{-2}$ & & \\
\hline & $2 \% Z-200$ & 672 & & $9.10 \times 10^{-2}$ & & \\
\hline & $2 \%$ Clinoptilolite & 672 & & $1.31 \times 10^{-1}$ & & \\
\hline & $2 \%$ AW- 300 & 672 & & $1.79 \times 10^{-1}$ & & \\
\hline \multirow[t]{7}{*}{$I-P$} & $2 \%$ AW -500 & 672 & & $4.60 \times 10^{-2}$ & & \\
\hline & $2 \% z-900$ & 672 & & $3.90 \times 10^{-2}$ & & \\
\hline & $2 \%$ Vermiculite & 672 & & $3.80 \times 10^{-2}$ & & \\
\hline & $2 \% Z-500$ & 672 & & $4.50 \times 10^{-2}$ & & \\
\hline & $2 \% z-200$ & 672 & & $6.50 \times 10^{-2}$ & & \\
\hline & $2 \% \mathrm{Cl}$ inoptilolite & 672 & & $9.20 \times 10^{-2}$ & & \\
\hline & $2 \%$ AW -300 & 672 & & $9.30 \times 10^{-2}$ & & \\
\hline
\end{tabular}


particle sizes of 0.4 and $0.1 \mathrm{~cm}$, respectively. Addition of $25 \mathrm{wt} \%$ zeolite reduces the fraction released to 0.012 , independent of particle size. No significant differences were found in ${ }^{137}$ Cs leachability in deionized and sea water.

\section{Alpha Emitter Leachability}

The leachability of alpha radioactivity emitters from concrete waste forms containing actual SRP sludges ranges from $\sim 10^{-5} \mathrm{~g} / \mathrm{cm}^{2} \cdot \mathrm{d}$ iritially to $210^{-8} \mathrm{~g} / \mathrm{cm}^{2} \cdot \mathrm{d}$ after 6 weeks with less than $10^{-3} \%$ Pu leached after 6 weeks. (33) Consistent with cesium and strontium leachability, alpha emitter leachability is a strong function of time; however, the data more closely follow a $\mathrm{t}^{-1}$ relationship (rather than $\mathrm{t}^{-1 / 2}$ ), indicating that leachability is controlled by factors other than diffusion within the matrix. These results are similar to those obtained from concrete waste forms containing simulated SRP sludges. (33) Plutonium leachabilities from samples containing $5 \times 10^{7}$ $\mathrm{dis} / \mathrm{min}$ of ${ }^{239} \mathrm{Pu}$, which range from $10^{-5} \mathrm{~g} / \mathrm{cm}^{2} \cdot \mathrm{d}$ initially to $10^{-8} \mathrm{~g} / \mathrm{cm}^{2} \cdot \mathrm{d}$ after 12 weeks, are strong functions of time, and are relatively unaffected by cement type, sludge type, and sludge content.

Leach rates for plutonium from simulated ILW cement products have been determined in four different leaching media. (65) Plutonium leachabilities in deionized water, $0.01 \mathrm{M} \mathrm{NaCl}$ solution, and $1 \mathrm{M} \mathrm{NaCl}$ solution are comparable and range from $2-11 \times 10^{-7} \mathrm{~g} / \mathrm{cm}^{2} \cdot \mathrm{d}$. In saturated carnallite solution the plutonium leach rate after 35 days is $\sim 5 \times 10^{-5} \mathrm{~g} / \mathrm{cm}^{2} \cdot d$. Carnallite solution corresponds to an equilibrium solution from waterleached natural salt deposits; its composition includes $62.83 \mathrm{wt} \% \mathrm{H}_{2} \mathrm{O}$, $2.04 \% \mathrm{MgSO}_{4}$, $34.3 \% \mathrm{MgCl}_{2}, 0.62 \% \mathrm{KCl}$, and $0.21 \% \mathrm{NaCl}^{(65)}$

Sodium Nitrate Leachability

Some typical, reported values of leach rates of $\mathrm{NaNO}_{3}$ and $\mathrm{Al}_{2} \mathrm{O}_{3}$-calcine cement composites are presented in Table 12. Leach tests with cement specimens containing aqueous $\mathrm{Na} \mathrm{NO}_{3}$ indicate a strong composition dependency on the 
leach rate of $\mathrm{NaNO}_{3} \cdot(43,44,45)$ The fraction of $\mathrm{NaNO}_{3}$ released after 14 days from a sample containing 15 wt $\% \mathrm{NaNO}_{3}$ is 0.61 while a sample containing $5 \%$ $\mathrm{NaNO}_{3}$ releases only 0.24 . Composites containing up to $15 \mathrm{wt} \% \mathrm{NaNO}_{3}$ demonstrate a greater compositional dependency than those with greater than 15 wt\%. In composites with less than 15 wt $\mathrm{NaNO}_{3}$, the concentration is sufficiently low to completely dissolve in water. The mechanism for composites with $<15 \mathrm{wt} \% \mathrm{NaNO}_{3}$ is believed to involve diffusion of $\mathrm{NaNO}_{3}$ from the pores within the cement matrix into the leachant. $(43,44)$ For composites with $>15 \mathrm{wt} \% \mathrm{NaNO}_{3}$, the species which diffuses out of the pores is replaced through the dissolution of excess $\mathrm{NaNO}_{3}$ present in the composite as aggregate. Furthermore, the $\mathrm{NaNO}_{3}$ exposed to the surface of the composite will be leached through dissolution.

An increase in temperature has been shown to contribute to an increase in the release rate of $\mathrm{NaNO}_{3} \cdot{ }^{(43)}$ Specimens containing 5,15 , and $30 \mathrm{wt} \%$ $\mathrm{NaNO}_{3}$ leach much faster at $60^{\circ} \mathrm{C}$ than at $25^{\circ} \mathrm{C}$, with $>97 \%$ leached within 32 days. The effects of radiation on the release of $\mathrm{NaNO}_{3}$ have also been investigated. $(43,44)$ Composites of $\mathrm{HAC}$ and $30 \mathrm{wt} \% \mathrm{NaNO}_{3}$, irradiated at $11.5 \times 10^{6} \mathrm{rads} / \mathrm{hr}$ in ${ }^{60}$ Co $\gamma$-irradiation, show no significant changes in $\mathrm{NaNO}_{3}$ released after a total integrated dose of $3.5 \times 10^{9}$ or $7 \times 10^{70}$ rads. (43) Another set of samples containing up to $30 \mathrm{wt} \% \mathrm{NaNO}_{3}$, irradiated to $10^{9}$ rads at a radiation intensity of $4.4 \times 10^{6} \mathrm{rads} / \mathrm{hr}$ in air at $\sim 68^{\circ} \mathrm{C}$, demonstrates no appreciable change in leachability over unirradiated samples. ${ }^{(44)}$

Cement type may also effect release of $\mathrm{NaNO}_{3}$ from concrete waste forms. Leach rates have been shown to be slightly lower for type II portland cement composites than for HAC formulations. (44) For low concentrations of $\mathrm{NaNO}_{3}$ the leach rates from portland cements are $\sim 20 \%$ those of HAC composites. The slight difference may be attributed to pore size and pore size distribution; the average pore size of $\mathrm{HAC}$ has been measured at $0.5 \mu \mathrm{m}$, compared to $0.095 \mu \mathrm{m}$ for portland cement. $(44)$

\section{Polymer-Impregnated Concrete}

Overall leachability of concrete waste forms can be reduced considerably by impregnating the interconnecting porosity with styrene monomer, 
TABLE 12. Reported Sodium Nitrate Leach Data for Various Concrete Waste Forms

\begin{tabular}{|c|c|}
\hline $\begin{array}{l}\text { Cennent } \\
\text { Type } \\
\end{array}$ & $\begin{array}{l}\text { Aggregate Type } \\
\text { and Amount, wt } \%\end{array}$ \\
\hline HAC & $\begin{array}{l}5 \% \mathrm{NaNO}_{3} \\
10 \% \mathrm{NaNO}_{3} \\
15 \% \mathrm{NaNO}_{3} \\
20 \% \mathrm{NaNO}_{3} \\
25 \% \mathrm{NaNO}_{3} \\
30 \% \mathrm{NaNO}_{3} \\
5 \% \mathrm{NaNO}_{3} \\
10 \% \mathrm{NaNO}_{3} \\
15 \% \mathrm{NaNO}_{3} \\
20 \% \mathrm{NaNO}_{3} \\
25 \% \mathrm{NaNO}_{3} \\
30 \% \mathrm{NaNO}_{3} \\
29.8 \% \mathrm{NaNO}_{3} \\
29.8 \% \mathrm{NaNO}_{3} \\
29.8 \% \mathrm{NaNO}_{3}\end{array}$ \\
\hline Portland II & $\begin{array}{l}5 \% \mathrm{NaNO}_{3} \\
25 \% \mathrm{NaNO}_{3} \\
7.4 \% \mathrm{NaNO}_{3}, 15.4 \% \text { flyash } \\
15.1 \% \mathrm{NaNO}_{3}, 13.9 \% \text { flyash } \\
25.0 \% \mathrm{NaNO}_{3}, 12.3 \% \text { flyash } \\
29.8 \% \mathrm{NaNO}_{3}, 11.5 \% \text { pumice } \\
29.8 \% \mathrm{NaNO}_{3}, 17.0 \% \text { pumice }\end{array}$ \\
\hline HAC & $\begin{array}{l}38.9 \% \mathrm{Al}_{2} \mathrm{O}_{3} \text { calcine } \\
38.9 \% \mathrm{Al}_{2} \mathrm{O}_{3} \text { calcine }\end{array}$ \\
\hline
\end{tabular}

\begin{tabular}{|c|c|c|c|c|}
\hline $\begin{array}{l}\text { Leach } \\
\text { Iíne }(h r)\end{array}$ & Bulk Leach Rate & $\begin{array}{l}\text { Fraction } \\
\text { Release }\end{array}$ & Corrunents & Reference \\
\hline$?$ & $\begin{array}{l}1.3 \times 10^{-3} \\
5.0 \times 10^{-3} \\
1.0 \times 10^{-2} \\
1.5 \times 10^{-2} \\
1.8 \times 10^{-2} \\
2.3 \times 10^{-2} \\
1.4 \times 10^{-3} \\
6.1 \times 10^{-3} \\
1.6 \times 10^{-2} \\
1.4 \times 10^{-2} \\
1.9 \times 10^{-2} \\
1.9 \times 10^{-2}\end{array}$ & & $\begin{array}{l}\text { Irradiated to } 10^{9} \mathrm{rads} \\
\text { at } 4.4 \times 10^{6} \mathrm{rads} / \mathrm{hr} \\
\text { at } 68^{\circ} \mathrm{C}\end{array}$ & 44 \\
\hline 168 & $8.0 \times 10^{-2}$ & $4.8 \times 10^{-1}$ & area volume $=1.87$ & 44 \\
\hline $\begin{array}{l}168 \\
168\end{array}$ & $\begin{array}{l}8.2 \times 10^{-2} \\
7.8 \times 10^{-2} \\
2.5 \times 10^{-4} \\
9.8 \times 10^{-3} \\
7.9 \times 10^{-4} \\
5.8 \times 10^{-3} \\
6.7 \times 10^{-3} \\
8.2 \times 10^{-3} \\
8.2 \times 10^{-3}\end{array}$ & $\begin{array}{l}2.5 \times 10^{-1} \\
1.2 \times 10^{-1}\end{array}$ & $\begin{array}{l}\text { area/volume }-0.95 \\
\text { area/volume }-0.48\end{array}$ & \\
\hline & $\begin{array}{l}7.0 \times 10^{-4} \\
6.8 \times 10^{-4}\end{array}$ & & $\begin{array}{l}\text { Irradiated to } 10^{10} \text { rads } \\
\text { at } 4.2 \times 10^{6} \mathrm{rads} / \mathrm{hr}\end{array}$ & 44 \\
\hline
\end{tabular}

\section{4}

44 
which is subsequently polymerized in situ. ${ }^{(40)}$ Styrene monomer containing a polymerization catalyst is allowed to soak into the concrete and heated to 50 to $70^{\circ} \mathrm{C}$ to induce polymerization. Benzoyl peroxide and AIBN[2,2'-Azobis (2-methyl propionitrile)] have been used as polymerization catalysts for styrene monomer at a concentration of $20.5 \mathrm{wt} \%$ in the monomer. (40) Polymerimpregnated concrete (PIC) specimens exhibit bulk leach rates at least two orders of magnitude lower than cement concrete specimens.

THERMAL ANALYSIS

Thermal Conductivity

Thermal conductivity is an important parameter in the evaluation of radioactive waste forms because of the heat generated as a result of radioactive decay. When thermal conductivity is extremely low, temperature gradients can be generated in sufficient magnitude to cause degradation of mechanical properties. BNL has conducted thermal conductivity measurements on several concrete samples containing simulated SRP sludges. $(35,36,37)$ The tests were conducted at $100^{\circ} \mathrm{C}, 200^{\circ} \mathrm{C}$, and again at $100^{\circ} \mathrm{C}$, allowing 30 minutes for equilibrating. Samples containing type II sludge were heated to $200^{\circ} \mathrm{C}$ prior to testing to remove any residual mercury. Some typical values to thermal conductivity reported for various concrete waste forms are given in Table 13. Addition of simulated SRP sludges to cement mixtures results in decreases in thermal conductivity with increasing sludge content, independent of sludge type. $(33,36)$ Residual water in concrete samples causes larger thermal conductivity values than for samples dried prior to testing, as evidenced by reported values at $100^{\circ} \mathrm{C}$. Thermal conductivity of dried samples increases with temperature from $100^{\circ}$ to $200^{\circ} \mathrm{C}$. Concrete waste forms consisting of HAC exhibit greater conductivities than similar formulations with type I-P cement.

Thermal conductivity has also been determined for $\mathrm{NaNO}_{3}$ concrete composities (See Table 13). Measurements were made at three temperatures, the selection of which was based on the initial temperature $\left(100^{\circ} \mathrm{C}\right)$ at which unbound or "free" water begins to evaporate and leave the composite, 
TABLE 13. Thermal Conductivity of Various Waste Forms

\begin{tabular}{|c|c|c|c|c|c|c|c|}
\hline \multirow{2}{*}{$\begin{array}{c}\text { Cement } \\
\text { Type } \\
\end{array}$} & \multirow{2}{*}{$\begin{array}{l}\text { Aggregate Type } \\
\text { and Amount, wt\% }\end{array}$} & \multicolumn{5}{|c|}{ Thermal Conductivity (BTU/hr $\mathrm{ft}^{\circ} \mathrm{F}$ ) } & \multirow[b]{2}{*}{ Reference } \\
\hline & & $100^{\circ} \mathrm{C}$ & $130^{\circ} \mathrm{C}$ & $150^{\circ} \mathrm{C}$ & $200^{\circ} \mathrm{C}$ & $100^{\circ} \mathrm{C}^{\star}$ & \\
\hline \multirow[t]{18}{*}{ HAC } & - & 0.56 & 0.44 & 0.42 & & & 36 \\
\hline & - & 0.57 & 0.57 & 0.56 & & & 35 \\
\hline & - & 0.70 & & & 0.63 & 0.49 & 33 \\
\hline & - & 0.59 & 0.57 & 0.56 & & & 43 \\
\hline & $40 \%$ SRP Sludge I & 0.53 & & & 0.58 & 0.30 & 33 \\
\hline & $40 \%$ SRP Sludge II & $0.33^{\star}$ & & & 0.51 & 0.36 & 33 \\
\hline & 10\% SRP Sludge III & 0.53 & & & 0.62 & 0.44 & 33 \\
\hline & 19.3\% SRP Sludge III & 0.31 & 0.29 & 0.29 & & & 35 \\
\hline & 19.3\% SRP Sludge III & 0.55 & 0.44 & 0.53 & & & 36 \\
\hline & $25.0 \%$ SRP Sludge III & 0.51 & & & 0.59 & 0.37 & 33 \\
\hline & $28.2 \%$ SRP Sludge III & 0.25 & 0.20 & 0.20 & & & 35 \\
\hline & $37.2 \%$ SRP sludge III & 0.38 & 0.28 & 0.23 & & & 36 \\
\hline & 46.2\% SRP Sludge III & 0.19 & 0.19 & 0.18 & & & 36 \\
\hline & $60 \%$ Wetted Zeolite & 0.25 & & & & & 35 \\
\hline & $7.2 \% \mathrm{NaNO}_{3}$ & 0.65 & 0.61 & 0.57 & & & 43 \\
\hline & $15.0 \% \mathrm{NaNO}_{3}$ & 0.67 & 0.61 & 0.56 & & & 43 \\
\hline & $20.0 \% \mathrm{NaNO}_{3}$ & 0.67 & 0.61 & 0.56 & & & 43 \\
\hline & $25.0 \% \mathrm{NaNO}_{3}$ & 0.69 & 0.68 & 0.64 & & & 43 \\
\hline \multirow[t]{6}{*}{$I-P$} & - & 0.51 & & & 0.56 & 0.37 & 33 \\
\hline & $40 \%$ SRP Sludge I & 0.42 & & & 0.46 & 0.25 & 33 \\
\hline & $40 \%$ SRP Sludge II & $0.20^{\star}$ & & & 0.34 & 0.24 & 33 \\
\hline & 10\% SRP Sludge III & 0.50 & & & 0.56 & 0.35 & 33 \\
\hline & $25 \%$ SRP Sludge III & 0.45 & & & 0.42 & 0.29 & 33 \\
\hline & $40 \%$ SRP Sludge III & 0.41 & & & 0.36 & 0.24 & 33 \\
\hline
\end{tabular}

*Preheated to $200^{\circ} \mathrm{C}$ before measurements were made. 
the temperature $\left(130^{\circ} \mathrm{C}\right)$ at which all the free water leaves the concrete, and the temperature $\left(150^{\circ} \mathrm{C}\right)$ at which dehydration starts. (43) The general trends evidenced by the data indicate increasing thermal conductivity with increasing $\mathrm{NaNO}_{3}$ content and decreasing temperature. At $150^{\circ} \mathrm{C}$, thermal conductivity appears to be relatively independent of $\mathrm{NaNO}_{3}$ concentration.

\section{$\underline{\text { DTA-TGA-EGA }}$}

Differential thermal analyses (DTA), thermogravimetric analyses (TGA), and effluent-gas analyses (EGA) have been conducted on various concrete waste forms. $(21,33,54)$ Weight losses of neat cement pastes determined by DTA, have been shown to be dependent on curing time. (54) Long curing times reduce the amount of free water in the pastes by allowing increased hydration of the cement consitituents. Cumulative weight losses for type III portland cement paste measured at $125^{\circ} \mathrm{C}$ are reported to be $6.3,5.8$, and $5.2 \mathrm{wt} \%$ for cure times of 1,7 , and 28 days, respectively. $(54)$ of the portland cements, cumulative weight losses were lowest for type I and highest for type II. HAC pastes demonstrate lower weight losses below $250^{\circ} \mathrm{C}$ than portland cements, but higher weight losses between $300^{\circ}$ and $500^{\circ} \mathrm{C}$ due to dehydration of aluminum hydroxide. Table 14 lists some reactions reported for various concrete waste forms and neat cement pastes determined by DTA-TGA-EGA. Addition of sludge to cement pastes results in DTA curves which can be approximated by addition of the respective sludge and cement curves indicating no significant interaction between cement and sludge. (21)

The combined effects produced by cement curing exotherms, waste heat generation, and sorbed and free water within the cement matrix may result in extreme pressures in a closed container. Tests conducted to determine the pressures generated during heating of concrete waste forms show that preheating the waste form to $150^{\circ} \mathrm{C}$ for 5 to 6 hours prior to sealing the canisters can limit pressures generated by steam to 250 psig at a temperature of $240^{\circ} \mathrm{C} .(27,33)$ with no preheating, canister pressures at $240^{\circ} \mathrm{C}$ may reach 450 to 500 psig. 
TABLE 14. Typical Reactions Occurring in Heated
Concrete Waste Forms $(29,33)$

\begin{tabular}{l} 
Temperature \\
Range, ${ }^{\circ} \mathrm{C}$ \\
\hline
\end{tabular}

$25-200$

$200-250$

$350-450$

$500-550$

$500-800$

$800-900$

\section{Reaction}

- Sorbed water, capillary water and water of crystallization are evolved from cement matrix.

- Hydroxyl water is evolved from $\mathrm{MnO}_{2} \cdot \mathrm{xH}_{2} \mathrm{O}$.

- Water is evolved from $\mathrm{Al}_{2} \mathrm{O}_{3} \cdot \mathrm{xH}_{2} \mathrm{O}$ in $\mathrm{HAC}$, Sludge I, and Sludge II.

- Water is evolved from $\mathrm{Fe}_{2} \mathrm{O}_{3} \cdot \mathrm{xH}_{2} \mathrm{O}$.

- Water is evolved from $\mathrm{Al}(\mathrm{OH}) 3$ in $\mathrm{HAC}$, Sludge I, and Sludge II.

- Hg0 in Sludge II decomposes.

- Water is evolved from $\mathrm{Ca}(\mathrm{OH})_{2}$ in Portland cement concretes.

- $\mathrm{MnO}_{2}$ reacts to release $\mathrm{O}_{2}$ and form $\mathrm{Mn}_{2} \mathrm{O}_{3}$.

- $\mathrm{CaCO}_{3}$ reacts to release $\mathrm{CO}_{2}$ and form $\mathrm{CaO}$.

- $\mathrm{Mn}_{2} \mathrm{O}_{3}$ reacts to release $\mathrm{O}_{2}$ and form $\mathrm{Mn}_{3} \mathrm{O}_{4}$. 


\section{RADIOLYTIC GAS PRODUCTION}

Concrete samples containing simulated SRP waste sludges have been irradiated by ${ }^{60}$ Co gamma rays and ${ }^{244} \mathrm{Cm}$ alpha particles to determine the extent of gas production due to radiolysis. $(67,68)$ Radiolysis of waste forms during long-term storage in sealed containers may produce gas pressures of sufficient magnitude to rupture the container. Gamma radiolysis of concrete containing $\mathrm{Fe}_{2} \mathrm{O}_{3}$ or $\mathrm{MnO}_{2}$ shows that $\mathrm{H}_{2}$ is the only gas produced in tests of both high and low dose rates. The magnitude of the dose rates is reported to affect both the initial production rate of $\mathrm{H}_{2}$ and the equilibrium pressure of $\mathrm{H}_{2}$; at higher dose-rates, larger steady-state pressures are achieved. (68) Differences in steady-state pressures are also caused by the type of simulated waste in the irradiated concrete as evidenced by higher pressures generated in samples containing reagent-grade $\mathrm{Fe}_{2} \mathrm{O}_{3}$ than in $\mathrm{MnO}_{2}$ samples. There is reported to be no effect of water/cement ratio on the equilibrium $\mathrm{H}_{2}$ pressure, however.

Tests on samples containing added $\mathrm{NO}_{3}{ }^{-}$and $\mathrm{NO}_{2}{ }^{-}$show that no additional pressurization results when irradiated at a dose rate of $8.9 \times 10^{4} \mathrm{rads} / \mathrm{hr}$. (68) At this dose rate $\mathrm{H}_{2}$ is produced, $\mathrm{O}_{2}$ is consumed and small amounts of $\mathrm{N}_{2} \mathrm{O}$ are produced. At a dose rate of $2.8 \times 10^{7}$ rads $/ \mathrm{hr} 0_{2}$ is produced, indicating that a different mechanism of radiolysis is present. It is also reported that $\mathrm{NO}_{3}{ }^{-}$and $\mathrm{NO}_{2}{ }^{-}$are reduced by the $\mathrm{H}$ atom formed by the radiolys is of water, thereby lowering the amount of $\mathrm{H}_{2}$ produced.

Organic compounds may decompose and form $\mathrm{H}_{2}, \mathrm{CO}_{2}$, and $\mathrm{CH}_{4}$ in the presence of radiation. $(67,68)$ Concrete samples containing high-alumina cement, Fe-Al simulated waste, and ascorbic acid $\left(\mathrm{C}_{6} \mathrm{H}_{8} \mathrm{O}_{6}\right)$ produce $\mathrm{H}_{2}$ upon gamma irradiation at $8.9 \times 10^{4} \mathrm{rads} / \mathrm{hr}$; pressurization does not reach steady state as in the case with no organic set retarder, however. Tests at higher dose rates $\left(1.4 \times 10^{7} \mathrm{rads} / \mathrm{hr}\right)$ indicate that pressurization due to $\mathrm{H}_{2}$ production in the presence of ascorbic acid set retarder reaches an equilibrium state at approximately 150 psi.

The effects of alpha radiation on concrete samples containing simulated wastes have been determined using ${ }^{244} \mathrm{Cm}$ as an alpha radiation source. $(67,68)$ 
The results differ from gamma radiolysis in that both $\mathrm{H}_{2}$ and $\mathrm{O}_{2}$ are produced with an $\mathrm{O}_{2} / \mathrm{H}_{2}$ ratio varying from 0.2 to 0.5 . Furthermore, a steadystate pressure is not achieved up to $200 \mathrm{psi}$. The effect of prolonged exposure and higher pressures was determined with concrete containing Fe-Mn simulated waste. The pressure increases linearly to 200 psi over a 4.5 -month period at a calculated dose rate of $4 \times 10^{5} \mathrm{rads} / \mathrm{hr}$. (69) A steady-state pressure of $\sim 50 \mathrm{psi}$ is predicted from gamma radiolysis for comparable dose rates indicating that different radiolytic mechanisms are operating under alpha radiation. The final gas composition resulting from the 4.5-month test indicates that water present in the samples was decomposed by alpha radiolysis to stoichiometric quantities. 


\section{LITERATURE REVIEW SECTION SUMMARY}

The following is a brief summary of selected properties of cements and concrete waste forms presented in the literature.

WATER/CEMENT RATIO

Water/cement ratios may vary with type of cement and type and amount of waste additions. SRP simulated and radioactive sludges are hydrophilic and react with cement components resulting in increases in the amount of water required to form a workable paste. The extent of reaction is expressed by an interaction coefficient which ranges from 0 to 1.49 depending on cement and sludge type. Additions of $\mathrm{NaNO}_{3}$ waste do not effect w/c.

\section{SET TIMES}

SRP sludges containing $\mathrm{Fe}(\mathrm{OH})_{3}$ and $\mathrm{Al}(\mathrm{OH})_{3}$ decrease set times of type II portland cement mixtures from 188 minutes to 8 minutes as a result of the heat of hydration of the two components. Commercial set retarders and/or excess water may be used to increase set times sufficiently to enable proper handling and process operations. Boric acid and borate wastes tend to increase set times and if present in sufficient quantities can prevent the mix from setting.

\section{CURING EXOTHERMS}

Temperatures resulting from hydration reactions in neat cement pastes may reach $152^{\circ} \mathrm{C}$ along the centerline of $12-i n$. diameter castings. Additions of aggregate to cement pastes decrease the rate and amount of heat evolved and the resultant centerline temperatures of cylindrical castings because of possible increases in thermal conductivity and heat capacity and/or decreasing amounts of cement components. Boric acid also decreases the rate of heat release and the total heat liberated during curing; commercial chemical set retarders have no significant effects. 


\section{COMPRESSIVE STRENGTH}

Neat cement pastes exhibit compressive strengths of approximately 10000 psi with portland cements developing $290 \%$ ultimate strength after 30 days and high-alumina cements developing $275 \%$ after only 3 days. Compressive strengths of cement-sludge samples progressively decrease with increasing sludge content; the decreases are primarily due to the lack of strength of the sludge particles. Neat cement pastes receiving gamma radiation exposures during curing exhibit lower compressive strengths than normally cured samples. Strength of high-alumina cement containing simulated sludges is not affected by heat or irradiation during curing. The same effect of waste additions is seen for steam-cured samples, i.e., strength is decreased in neat pastes but unaffected by sludge additions. Specimens heated at $100^{\circ} \mathrm{C}$ for 3 months exhibit $225 \%$ lower stengths than unheated samples of indentical formulations. Gamma irradiation effects on the strength of cured samples are minimal. Sorbents alone tend to decrease strength; however, formulations with sludge plus sorbent exhibit strengths that are higher than those of formulations with sludge or sorbent alone.

\section{LEACHABILITY}

Strontium leachability is a strong function of time, decreasing by factors of 10 to 200 over a 6-week period. Leachability varies with sludge type and decreases with increasing sludge content in some cases and increases in others. Long cure times and irradiation tend to decrease leachability while prolonged exposure to high temperatures and increased leachant renewal frequency tend to increase leachability. Cesium leachability is generally greater than strontium leachability but decreases by 10 to 400 times with sorbent additions. Plutonium leach rates from various formulations range from $\sim 10^{-5}$ to $10^{-8} \mathrm{~g} / \mathrm{cm}^{2} \cdot \mathrm{d}$.

\section{THERMAL CONDUCTIVITY}

Thermal conductivity generally decreases with increasing waste additions and residual water content. Cement- $\mathrm{NaNO}_{3}$ samples demonstrate increasing thermal conductivity with increasing $\mathrm{NaNO}_{3}$ content and decreasing temperature. 


\section{FEASIBILITY OF INCORPORATING HIGH ACTIVITY WASTE IN CONCRETE}

The radioactive waste described and discussed in this section is assumed to be the solidified product of high-level liquid radioactive waste generated from the primary co-decontamination cycle of a nuclear fuel reprocessing facility. High-level liquid waste is a solution of nitrate salts and nitric acid with three catagories of constituents. The relative non-volatile oxide content of these constituents are:(2)

1) $28 w t \%$ inerts (non-radioactive reprocessing chemicals),

2) $57 \mathrm{wt} \%$ fission products, and

3) $15 w t \%$ actinides.

These values are for fuel irradiated at a power level of 35 MW/MTU to a total burnup of $25000 \mathrm{MWd} / \mathrm{MTU}$. The radioactivity decay heat generation rates for the waste are a function of time out of reactor and are 18.5, 9.2, and $0.86 \mathrm{~kW} / \mathrm{MTU}$ for 160 days, 1 year, and 10 years, respectively. (2) The total activity of the waste is $21.6 \times 10^{6} \mathrm{Ci} / \mathrm{MTU}$ after a 1-year cooling period. (1) For purposes of discussion it is assumed that reprocessed spent fuel equivalent to 1500 MTU will be solidified per year processing 5 MTU/day operating 300 days/year.

The major factors affecting the feasibility of incorporating high activity waste in concrete include:

- potential radiolysis problems

- alpha and gamma radiation damage

- high heat generation rates

- low thermal conductivity

- low product temperature limitations

- leachability of radionuclides

- strength of the waste form.

\section{LITERATURE REVIEW}

To date, no data have been found in the literature on the incorporation of light water reactor fuel cycle HLW in concrete. 


\section{DISCUSSION}

\section{Heat Transfer and Waste Loading Considerations}

Four major factors dictating waste loading limitations include:

1) volumetric heat generation,

2) thermal conductivity,

3) canister diameter, and

4) product limiting temperature.

Although the thermal conductivity of concrete waste forms incorporating HLW calcine may vary with waste content, moisture, and temperature, no absolute values are available and calculations have been performed under the assumption of constant thermal conductivity. Furthermore, the maximum temperature permitted within a canister of HLW concrete has not been established. References made to a limiting centerline temperature are chosen within a temperature range that is not expected to seriously threaten product integrity, solely for the purpose of discussion and comparison. Canister centerline temperatures were calculated utilizing the heat transfer relationship used by Hoskins and Berreth for canister storage of highlevel solidified waste. ${ }^{(69)}$ For waste stored in a solid cylinder, the centerline temperature, $T_{1}$, and wall temperature, $T_{2}$, are calculated by:

$$
\begin{aligned}
& T_{1}=\frac{1}{R k h}\left[\frac{Q R^{2}}{2}\left(\frac{1+h R}{2 k}\right)+h R T_{0}\right] \\
& T_{2}=T_{1}-\frac{Q R^{2}}{4 k}
\end{aligned}
$$

where,

$\mathrm{R}=$ canister radius, $\mathrm{m}$

$\mathrm{k}=$ thermal conductivity, $\mathrm{W} / \mathrm{m}^{\circ} \mathrm{C}$

$h=$ heat transfer coefficient

$Q=$ volumetric heat generation, $W / \mathrm{m}^{3}$

$\mathrm{T}_{0}=$ ambient temperature, ${ }^{\circ} \mathrm{C}$ 
For free convection in air with a turbulent boundary layer,

$$
h=1.31\left(T_{2}-T_{0}\right)^{1 / 3}
$$

The above equations are solved iteratively to obtain $T_{1}$ and $T_{2}$. A11 calculations were performed under the conditions that ambient temperature is $30^{\circ} \mathrm{C}$ and the canister acts as an infinite cylinder with heat transferred along the radial direction. Due to the low product limiting temperature, radiation heat transfer has been neglected and heat transfer within the canister is assumed to be by conduction only.

To eliminate the need for assuming the exact physical form of the waste to be incorporated in cement, waste loading and material requirement calculations are based on the total heat generated by the waste. Assuming 1-year old waste with a radioactive decay heat generating rate of $9.2 \mathrm{~kW} / \mathrm{MTU}$, $13800 \mathrm{~kW} /$ year must be encapsulated. Similarly, 5-year old waste requires encapsulation of $2550 \mathrm{~kW} /$ year. Tables 15 and 16 list material requirements for canisters of concrete waste forms limited to centerline temperatures of $200^{\circ}$ and $300^{\circ} \mathrm{C}$, respectively, illustrating the effects of diameter and thermal conductivity. For the purpose of discussion and comparison, calculations were performed for a sample case with the following assumptions:

- centerline temperature limited to $200^{\circ} \mathrm{C}$

- thermal conductivity of $0.6 \mathrm{~W} / \mathrm{m}^{\circ} \mathrm{C}\left(0.35 \mathrm{BTU} / \mathrm{hr} \cdot \mathrm{ft}^{\circ} \mathrm{F}\right)$

- canister is $3 \mathrm{~m}$ long; wall thickness is $1.27 \mathrm{~cm}$; density is $7 \mathrm{~kg} / \mathrm{L}$

- heat generation is $9.2 \mathrm{~kW} / \mathrm{MTU}$

- 1500 MTU is processed per year

- conductive heat transfer relationship (69)

- no temperature dependency on thermal conductivity

- no waste dependency on thermal conductivity.

As evidenced in Table 15, the total number of $0.5-\mathrm{m}$ diameter canisters required per year is 6220 compared to $144600.1-\mathrm{m}$ diameter canisters; however, the total annual mass of canister material for the larger canisters is much greater -- 282 tonnes compared to 123 tonnes. Figure 4 shows the 
fractional change of these two requirements in addition to the annual volume of cement and volume of waste per canister as a function of canister diameter for the aforementioned sample case. The optimum waste loading and canister diameter must be determined by evaluating the relative importance of each of the requirements.

The results presented for the above sample case are derived from many assumptions, and a large variance may occur under different conditions and restrictions. The relationship of thermal conductivity, canister diameter, and volumetric heat generation to canister centerline temperature is depicted in Tables 17 and 18 and in Figures 5 through 12. The independent variables used in these theoretical calculations are chosen to illustrate comparative relationships of canister centerline temperature under varying conditions. The conditions and resultant temperatures may not be directly applicable to concrete waste forms because of relatively low product limiting temperatures but may apply to glass or various alternative waste forms. Table 19 lists the maximum canister diameters permissible for specified volumetric heat generation, thermal conductivity, and canister centerline temperature. Similarly, Table 20 and Figures 13 and 14 give the maximum volumetric heat generation allowed in canisters of specified diameter, thermal conductivity, and centerline temperature. The relationships depicted in the above tables and figures can be used as a guide in. determining the possibility and feasibility of incorporating radioactive waste in concrete; however, while a number of parameter combinations may make the process theoretically possible, a particular set of parameters may provide more favorable economic and technological advantages. For example, by limiting the canister centerline temperature to $200^{\circ} \mathrm{C}$, volumetric heat generation of the waste form can vary from $0.5 \mathrm{~W} / \mathrm{L}$ in a canister with a diameter of $0.5 \mathrm{~m}$ and an effective thermal conductivity of $0.2 \mathrm{~W} / \mathrm{m}^{\circ} \mathrm{C}$ to $22.4 \mathrm{~W} / \mathrm{L}$ in a canister with a diameter of $0.1 \mathrm{~m}$ and a thermal conductivity of $1.0 \mathrm{~W} / \mathrm{m}^{\circ} \mathrm{C}$. The total heat permitted per canister for a given set of parameters dictates the number of canisters required to process 1500 MTU solid waste as seen in Table 21 and Figures 15 and 16. Obviously, the conditions which require the least number of canisters are those that allow 
the largest total heat content per canister (not the largest volumetric heat generation). Within the range of conditions of this study, these conditions are a diameter of $0.5 \mathrm{~m}$ and a thermal conductivity of $1.0 \mathrm{~W} / \mathrm{m}^{\circ} \mathrm{C}$ for a limiting centerline temperature of $200^{\circ} \mathrm{C}$. Minimizing the number of canisters may be desirable from the standpoint of process economics, handling, and technological simplicity; however, for a given set of conditions, as the number of canisters decreases, the total amount of materials required to produce the canisters increases (See Figures 17 and 18). This may be a concern when raw material conservation and/or material costs are considered. For the sample case the number of canisters required per year is 14460 and 6220 for 0.1 - and 0.5-m diameters, respectively. The annual material weight of the canisters increases from 123 tonnes to 282 tonnes, which means that the amount of chromium and nickel required ranges from 22.1 to 53.4 tonnes and 16.4 to 39.4 tonnes, respectively, assuming the canisters are type 316 stainless steel. The total weight of the encapsulated waste form increases by a factor of 10 when the larger diameter canisters are used.

The radioactivity decay heat generation rates of radioactive waste is a strong function of time out of reactor as evidenced in Figure 19. Allowing a "cooling off" period prior to solidification greatly lessens the material requirements by permitting more total waste in the canisters. Table 22 shows calculated material requirements for solidifying waste in concrete with a volumetric heat generation of $8.5 \mathrm{~W} / \mathrm{L}$ of solidified product, a canister diameter of $0.3 \mathrm{~m}$, and a thermal conductivity of $0.6 \mathrm{~W} / \mathrm{m}^{\circ} \mathrm{C}$. In this case, the amount of waste incorporated within the canister increases with cooling time resulting in a decrease in the number of canisters required per year from 7657 to 716 and a corresponding reduction in total annual canister weight by a factor of 11 after 10 years. The above sample case assumes a constant volumetric heat loading and canister diameter. Table 23 shows material requirements calculated with a constant volume percentage of waste per canister. The diameter and volumetric heat loading are dependent on the time out of reactor and on a limiting centerline temperature of $200^{\circ} \mathrm{C}$. For both cases the thermal conductivity 
was assumed to be $0.6 \mathrm{~W} / \mathrm{m}^{\circ} \mathrm{C}$.

Temperatures generated within canisters of solidified radioactive waste decrease with time as seen in Figure 20. The waste is assumed to be solidified in a 0.3-m diameter canister after a 1-year cooling period. The volumetric heat generation at time of solidification is $14.5 \mathrm{~W} / \mathrm{L}$; after 10 years it is reduced to $1.36 \mathrm{~W} / \mathrm{L}$.

\section{Comparison of Concrete and Borosilicate Glass}

Vitrification is considered a prime candidate for the solidification of power reactor HLW. (2) HLW oxides are mixed with glass-forming additives and melted by either a batch or continuous process. Typical characteristics of borosilicate glass include: (2)

- Waste oxide content

$20-35 w t \%$

- Typicar volume

60-80 L/MTU

- Density

$3.0-3.6 \mathrm{~kg} / \mathrm{L}$

- Thermal conductivity

$0.9-1.3 \mathrm{~W} / \mathrm{m}^{\circ} \mathrm{C}$

- Leach rate

- Processing temperature

$1000^{\circ}-1400^{\circ} \mathrm{C}$

- Maximum centerline temperature

$800^{\circ} \mathrm{C}$

Results of calculations of material requirements for the immobilization of HLW in glass are compared to those of concrete waste forms in Table 24. The calculations are based on a centerline temperature of $800^{\circ} \mathrm{C}$, volumetric heat generation rates of 115 and $153 \mathrm{~W} / \mathrm{L}$, thermal conductivity values of 0.9 and $1.3 \mathrm{~W} / \mathrm{m}^{\circ} \mathrm{C}$, and a glass density of $3.3 \mathrm{~kg} / \mathrm{L}$. Because of higher thermal conductivities and larger limiting temperatures, more waste can be incorporated in the canisters of glass, resulting in fewer canisters required per year.

\section{Potential Processing Problems}

The preceding discussion on heat transfer and waste loading illustrates the possibility of incorporating radioactive waste in concrete utilizing various combinations of diameter and waste loading that limit centerline temperature to a desired value. However, problems encountered during 
processing procedures prior to filling a canister with a cement/waste mixture may prove to be a prohibitive factor in the assessment of technological feasibility. Furthermore, assuming the waste mixture can be put in canisters, there may exist additional problems which require identification and subsequent rectification if HLW immobilization in concrete is to prove feasible. The many potential problems associated with the process are a direct result of the radioactive decay heat of the waste, the water content of the mix, and the radioactivity of the waste. Factors affecting the overall feasibility of immobilizing HLW in concrete are discussed for four processing steps:

1) mixing of waste, cement, and water,

2) casting the mixture into canisters,

3) curing of the cement/waste mixture, and

4) short-term and long-term storage.

Mixing of the waste, cement, and water to form a castable paste is assumed to be accomplished by conventional, mechanical means (i.e., tumbling, mechanical stirring, etc.). The preceding section defines the amount of waste allowed for a desired maximum centerline temperature and canister diameter; this amount of waste is added to predetermined amounts of cement and water and mixed until a paste with appropriate workability is attained. Under these batch conditions the heat generated by the waste would cause temperatures within the paste to exceed the boiling point of water. As an example, a 0.3-m diameter canister may contain approximately $6.3 \%$ waste resulting in a volumetric heat generation of $14.5 \mathrm{~W} / \mathrm{L}$ and a centerline temperature of $300^{\circ} \mathrm{C}$ for a thermal conductivity of $0.6 \mathrm{~W} / \mathrm{m}^{\circ} \mathrm{C}$. The total volume of cement/waste paste to be mixed per batch is $212 \mathrm{~L}$. Assuming the paste is mixed in a spherically shaped vessel with a volume of $424 \mathrm{~L}$, the calculated vessel diameter is $0.93 \mathrm{~m}$. Temperatures within the vessel may theoretically reach $800^{\circ}$ to $1000^{\circ} \mathrm{C}$ depending on thermal conductivity and the rate of heat dissipation. An alternative to batch mixing could involve a semi-continuous process where measured quantities of water and a powdered mixture of cement and waste are introduced at the head end of a continuous, flow-through mixer that is cooled to less than 
$100^{\circ} \mathrm{C}$. A continuous stream of cement/waste paste exits the mixer and is cast into canisters. While this type of mixing process may alleviate the problem of excessing temperatures, technological simplicity is sacrificed.

Problems during mixing (either batch or semi-continuous) may also be caused by radiolysis of liquid water and organic conpounds by alpha and gamma radiation. Studies at Savannah River have shown that gamma radiolysis of concrete waste forms produces $\mathrm{H}_{2}$ which eventually reaches equilibrium in a closed system. ${ }^{(68)}$ Alpha radiolysis of similar waste forms produces $\mathrm{H}_{2}$ and $\mathrm{O}_{2}$ with no equilibrium pressure up to 200 psi within a closed container. The magnitude of gas production was shown to be dose rate dependent for both cases. Dose rates from HLW may be as much as 100 times those studied at SRL. During the mixing operation, radiolysis of the water may cause significant amounts of hydrogen and oxygen gas to be produced within the slurry. Problems arise because of the lack of an escape route for the gases resulting in violent agitation or "bubbling" of the wet paste. Additional problems may be encountered as a direct result of hydrogen gas production. Safeguards against hydrogen explosions would have to be added to the system resulting in increased technological complexity.

When the desired consistency of the cement/waste paste is attained, the mixture is cast into cylindrical canisters. The major problem that may be encountered during casting is the setting of the paste before it can be transferred to the canister. Premature setting, which can be caused by heat or reactions between cement and waste, can be controlled by additions of chemical set retarders during the mixing operations.

Many of the problems associated with mixing may also be encountered during curing. Heat generated by the waste and by hydration reactions may produce temperatures in excess of the boiling point of water causing violent agitation of the mixture. Sealing the canister during curing will create pressures due to water vapor that could prevent boiling of the residual water. Additional sources of pressurization may include radiolysis of unbound water and organic set retarders which produces $\mathrm{H}_{2}, \mathrm{O}_{2}$, and possible other gases. The total pressure generated in the closed system 
may reach sufficient magnitude to rupture the canister; therefore, pressure relief valves would be required to maintain a pressure greater than that required to prevent boiling but less than the pressure that would threaten canister integrity and safety. When the mixture is set, the canister would be vented to allow the unbound water within the canister to escape. The time required for all the unbound water to be eliminated from the product is expected to be excessively long because only one end of the cylinder would be exposed. This problem may be alleviated by providing a path of escape for the water not directly exposed to the open end. Encapsulation of HLW in Hot-Pressed Cement

Workers at The Pennsylvania State University have encapsulated simulated $\mathrm{PW}-4 \mathrm{~b}, \mathrm{PW}-4 \mathrm{c}, \mathrm{PW}-6$, and calcined PW-6 in cement cylinders using hot-pressing techniques. $(49-52)$ The hot-pressing operations were performed at pressures ranging from 25000 to 100000 psi and temperatures from $150^{\circ}$ to $400^{\circ} \mathrm{C}$. Hot-pressed cement products possess properties superior to those of normally hydrated and cured concrete. Interconnecting porosity is virtually eliminated with the samples containing $\sim 3 \%$ closed porosity, compared to 20-30 vol\% porosity in ordinary concrete forms. The main advantages of hot-pressed cement over normal concrete for the isolation of radioactive waste include:

- compressive strengths of 235000 psi

- lower water content (less potential for radiolysis problems)

- lower leachability

- increased thermal conductivity and thermal stability.

Samples containing $\mathrm{PW}-4 \mathrm{C}$ and Fondu $\left(40 \% \mathrm{Al}_{2} \mathrm{O}_{3}\right)$ cement, hot pressed at $50000 \mathrm{psi}$, for 30 minutes at a temperature of $150^{\circ} \mathrm{C}$, exhibits decreases in strength with increasing waste content. This relationship is depicted in Figure 21. Although strength reductions were considerable with $50 \%$ PW-4c content, overal1 strengths for a 11 formulations are vastly superior to normally hydrated and cured concrete waste forms. (33) Hot-pressed cement samples prepared with Fondu cement and $40 \% \mathrm{PW}-4 \mathrm{c}$ exhibit compressive strengths on the order of 20000 psi, compared to 25000 psi for normally 
cured samples of HAC plus $40 \%$ simulated SRP sludges. Thermal shock resistance of hot-pressed samples was tested by immersion of samples heated to $760^{\circ} \mathrm{C}$ in cold water; no signs of cracking or disintegration were evidenced. Furthermore, heating of Fondu cement plus $20 \%$ PW- 6 at $230^{\circ} \mathrm{C}$ causes an initial strength increase up to 24 hours, followed by a gradual decrease through 28 days. (49)

The lower water content of hot-pressed cement samples, generally about $30 \%$ that required for normally hydrated and cured cement pastes, allows the production of high strength, high density products. Leachability and volume stability are expected to be superior to ordinary cement pastes because of the absence of interconnecting porosity within the hot-pressed samples. Thermal conductivity also increases with increasing density as evidenced in the relationship proposed by Tye and Spinney: $(70)$

$$
k=5.52 \times 10^{-7} \rho^{2}-4.9 \times 10^{-4} \rho+0.221
$$

where,

$$
\begin{aligned}
& k=\text { thermal conductivity, } \mathrm{w} / \mathrm{m}^{\circ} \mathrm{C} \\
& \rho=\text { density, } \mathrm{kg} / \mathrm{m}^{3} .
\end{aligned}
$$

Concrete composites containing $40 \%$ simulated SRP waste sludges have initial densities of $21700 \mathrm{~kg} / \mathrm{m}^{3}$. (33) After heating for 3 months at $100^{\circ} \mathrm{C}$, specimens containing type I-P cement plus 40\% sludge I demonstrated weight losses of $216 \%$, resulting in a "dry" density of $1428 \mathrm{~kg} / \mathrm{m}^{3}$. Evaluating the above equation with this density gives a thermal conductivity of $0.647 \mathrm{~W} / \mathrm{m}^{\circ} \mathrm{C}$, which compares to the measured values of 0.411 and $0.796 \mathrm{~W} / \mathrm{m}^{\circ} \mathrm{C}$ at $100^{\circ}$ and $200^{\circ} \mathrm{C}$, respectively. $(33,36)$ Similarly, evaluating the above equation for hot-pressed samples with a nominal density of $2700 \mathrm{~kg} / \mathrm{m}^{3}(49)$ yields a thermal conductivity of $2.92 \mathrm{~W} / \mathrm{m}^{\circ} \mathrm{C}$.

Hot-pressing operations require processing temperatures of $100^{\circ}$ $400^{\circ} \mathrm{C}$. (49) The heat generated from radioactive decay of the waste may 
be used to achieve these temperatures. Two approaches that may be used include: 1) the incorporation of a calculated amount of waste sufficient to achieve the desired temperature in a container of specified diameter, and 2) the incorporation of a specified amount of waste in a container with a diameter sufficient to attain a desired temperature. As an example of the latter approach, the canister diameter which results in a $400^{\circ} \mathrm{C}$ centerline temperature for a thermal conductivity of $2.5 \mathrm{~W} / \mathrm{m}^{\circ} \mathrm{C}$ and a volumetric heat generation of $60 \mathrm{~W} / \mathrm{L}$ is calculated to be $0.375 \mathrm{~m}$. Under these conditions, a temperature gradient of $211^{\circ} \mathrm{C}$ exists between the surface and center of the cylinder resulting in a surface temperature of $189^{\circ} \mathrm{C}$ when cooled by natural convention to air at $30^{\circ} \mathrm{C}$. Many combinations of diameter and volumetric heat generation give rise to desired temperatures within the waste forms.

Relatively large thermal conductivities of hot-pressed cement waste forms coupled with high limiting temperatures reduces material requirements significantly over those of conventional concrete waste forms. Tables 25 and 26 list material requirements for hot-pressed cement waste forms limited to centerline temperatures of $400^{\circ}$ and $700^{\circ} \mathrm{C}$, respectively. Thermal conductivity is assumed to be $2.5 \mathrm{~W} / \mathrm{m}^{\circ} \mathrm{C}$ (based on density), the heat generation rate is $9200 \mathrm{~W} / \mathrm{MTU}$, and the bulk density of the hot-pressed cement is $2.7 \mathrm{~kg} / \mathrm{L}$, independent of waste content. Tables 24, 25, and 26 illustrate the comparability of hot-pressed cement and borosilicate glass for the solidification of high-level wastes.

\section{Conceptual HLW Immobilization Process}

Immobilization of power reactor HLW in concrete requires several processing and storage steps. In the conceptual process, dry, HLW oxide powder is mixed with hydraulic cement to form a homogeneous blend. This mixture is blended with water and mixed until the desired consistency is attained, at which time the wet paste is cast into cylindrical canisters and allowed to cure. The cured waste form canisters are sealed, stored, and eventually placed in a repository. Although the entire process appears rather simple, many complications may. result during processing 
and storage that require attention if this solidification alternative is to prove feasible.

The conceptual process is discussed in terms of mixing, casting, curing, and storage of mixtures of waste, cement, and water. The waste is assumed to be high-level waste oxides (calcined HLLW) with an initial heat generation of $9200 \mathrm{~W} / \mathrm{MTU}$ and yearly output of 1500 MTU. The cement/ waste mixture is cast in 0.3-m (12-in) diameter, 3-m long cylindrical canisters. The waste content of the mixture is 3.6 vol\% resulting in a volumetric heat generation of $8.3 \mathrm{~W} / \mathrm{L}$ for an arbitrarily selected limiting temperature of $200^{\circ} \mathrm{C}$ and a thermal conductivity of $0.6 \mathrm{~W} / \mathrm{m}^{\circ} \mathrm{C}$. Temperatures within the wet cement/waste mixture are maintained at less than $100^{\circ} \mathrm{C}$ during mixing and casting, less than $2150^{\circ} \mathrm{C}$ during curing, and less than $200^{\circ} \mathrm{C}$ during storage.

\section{Mixing and Casting}

HLW calcine is blended with hydraulic cement to form a homogeneous, dry mixture. The powder, which is cooled to a temperature less than $100^{\circ} \mathrm{C}$ to prevent vaporization of the water, is continuously metered into a mixer and blended with predetermined amounts of water. The mixing process may be either continuous, where a controlled flow of powder and water are combined at the head end of a continuous mixer and the paste exits at a constant flow rate, or multiple-batch mixing where several small batches are mixed simultaneously. These two mixing processes faci1itate heat removal since the temperature during mixing must not exceed the boiling point of water. The mixers are coupled to an offgas system for treatment of gases produced by radiolysis and water vapor should the temperature exceed $100^{\circ} \mathrm{C}$. Mixing continues until a paste of desired consistency is attained, at which time the paste is cast into a $0.3-\mathrm{m}$ diameter canister that has a perforated tube running the length of the canister through the centerline. The canister is cooled during casting to insure a temperature of less than $100^{\circ} \mathrm{C}$ within the paste. Processing $5 \mathrm{MTU} / \mathrm{d}$ requires 25 canisters, or approximately one per hour, with each canister containing $218 \mathrm{~L}$ of product and weighing $465 \mathrm{~kg}$. 


\section{Curing}

The filled canisters are sealed with a lid containing a pressure control valve connected to an offgas system. The concrete waste form is allowed to cure under a pressure that is sufficient to inhibit boiling of the unbound water. Pressures caused by radiolysis and water vapor are maintained at a level which satisfies the above condition while not threatening canister integrity and safety. Temperature increases caused by radioactive decay heat and hydration of cement components are controlled to limit the temperature to a level that, when coupled with the pressure within the canister, prevents boiling. When the mixture has set, i.e., achieved a state of rigidity, the canister is vented and the unbound water is allowed to escape. The perforated tube through the centerline acts as an escape path for the water not directly exposed to the top surface. Canisters remain vented until all the unbound water is driven off. Two or three days may be required for complete drying, requiring floor space and offgas facilities capable of handling 50-75 canisters during one period.

\section{Storage}

When the water has been driven off, the canisters of concrete waste forms are sealed and stored for a period of time prior to ultimate disposal in a repository. The amount of waste contained in each canister is determined by the thermal characteristics of the waste form, i.e., thermal conductivity and product limiting temperature, and the canister diameter and volume. The storage facility for waste canisters, assuming a 10-year storage period, must be capable of accommodating 76000 canisters, each weighing $465 \mathrm{~kg}$. See Table 27 for selected material requirements calculated for concrete waste forms encapsulated in 0.3-m (12-in) and $0.15-m(6-i n)$ diameter canisters with a limiting centerline temperature of $200^{\circ} \mathrm{C}$ and a thermal conductivity of $0.6 \mathrm{~W} / \mathrm{m}^{\circ} \mathrm{C}$ for 1 -year and 5 -year cooled waste. 


\section{FEASIBILITY SECTION SUMMARY}

The radioactive waste discussed in the feasibility section is the solidified product of high-level liquid waste generated from power reactor fuel irradiated at a power level of 35 MW/MTU to a total burnup of $25000 \mathrm{MWd} / \mathrm{MTU}$ with reprocessed spent fuel equivalent to 1500 MTU solidified per year. The radioactivity decay heat generation rate and total activity of the waste are $9.2 \mathrm{~kW} / \mathrm{MTU}$ and $1.6 \times 10^{6} \mathrm{Ci} / \mathrm{MTU}$, respective $1 \mathrm{y}$, after one year out of reactor. Theoretical calculations, relating volumetric heat generation, thermal conductivity, canister diameter, and temperature, indicate several parametric combinations may make possible the incorporation of HLW in concrete. From these many combinations, a particular set of parameters may provide more favorable economic and technological advantages. Identifying the exact conditions is not possible because of the lack of absolute property values and criteria. The general trends, however, can be summarized as follows:

- Canister centerline temperature increases with:

1) increasing diameter, $f\left(r^{2}\right)$

2) decreasing thermal conductivity, $f(1 / k)$

3) increasing volumetric heat generation, $f(Q)$

- The number of canisters required to encapsulate 1500 MTU increases with:

1) decreasing diameter

2) decreasing thermal conductivity

3) decreasing product 7 imiting temperature

4) decreasing heat content per canister

5) decreasing time out of reactor before solidification

- Total mass of concrete waste forms increases with:

1) decreasing diameter

2) decreasing thermal conductivity

3) decreasing product limiting temperature

4) decreasing waste content per canister. 
The number of canisters required to encapsulate 1500 MTU HLW in concrete is 7 to 22 times the number of waste-glass canisters required because of lower product temperatures $\left(200^{\circ} \mathrm{C}\right.$ vs. $\left.800^{\circ} \mathrm{C}\right)$ and 1 ower thermal conductivity $\left(20.6 \mathrm{~W} / \mathrm{m}^{\circ} \mathrm{C}\right.$ vs. 0.9 to $\left.1.3 \mathrm{~W} / \mathrm{m}^{\circ} \mathrm{C}\right)$. Material requirements are lessened and product qualities improved if HLW is incorporated in hotpressed cement because of increases in compressive strengths, hightemperature stability, and thermal conductivity. Strengths of hot-pressed products may be ten times those of normally hydrated and cured concrete waste forms; thermal conductivity is estimated to be up to four times greater based on a proposed density dependency of thermal conductivity.

The heat generation rate of 1-year old waste may be a prohibitive factor in the feasibility assessment of HLW immobilization in concrete. The radioactivity decay heat diminishes from $9200 \mathrm{~W} / \mathrm{MTU}$ after 1-year cooling to $1700 \mathrm{~W} / \mathrm{MTU}$ and $860 \mathrm{~W} / \mathrm{MTU}$ after 5- and 10-year cooling periods, respectively. Similarly, the total number of canisters and total wasteform volume decreases in direct proportion with heat generation, i.e., by factors of 5.4 and 10.7 after cooling periods of 5 and 10 years, respectively.

Problems associated with radiolytic gas production are anticipated during all phases of HLW solidification in concrete. Large quantities of $\mathrm{H}_{2}, \mathrm{O}_{2}$, and water vapor may be produced during mixing and casting operations resulting in violent agitation or bubbling of the wet mixture. During storage in a closed system, excessive pressures may be generated, necessitating pressure regulations and offgas treatment. 


\section{CONCLUSIONS}

The major conclusions of this review are as follows:

- Hydraulic cements are considered candidates for the immobilization of low-level, intermediate-level, and aged, defense high-level wastes because of inexpensive raw materials, low processing temperatures, and relative processing simplicity.

- Concrete waste forms incorporating simulated wastes demonstrate relatively acceptable thermal, chemical, physical, and radiolytical stability.

- Concrete waste forms with radioactive SRP sludges have properties comparable to those of simulated waste products

- The properties of HLW that pose the greatest threat to economic and technological feasibility are the initial levels of radioactivity decay heat (9200 W/MTU) and specific activity $\left(\sim 1.6 \times 10^{6} \mathrm{Ci} / \mathrm{MTU}\right)$ because of their effects on water and organic compounds.

- Immobilization of HLW in concrete appears infeasible, both technologically and economically, in lieu of processing difficulties and material volumes because heat generating rates and radioactivity levels of power reactor fuel cycle HLW are at least two orders of magnitude greater than those of other wastes considered for immobilization in concrete.

- Allowing the HLW to cool prior to solidification decreases material requirements and potential radiolysis problems because of decreases in heat generation and radioactivity.

- Concrete waste forms are generally inferior to glass forms regarding radionuclide leachability, thermal conductivity, maximum product temperatures, compressive and impact strength, radiation effects (radiolysis of water in concrete), and required material outputs (canisters, total mass, offgas, etc.) 
- Immobilization of power reactor fuel cycle HLW in hot-pressed cement appears more attractive than conventional cement processes because of improved product qualities and less potential for radiolysis; however, the complexity of the hot-pressing operations may be a serious drawback. 
TABLE 15. Material Requirements for the Incorporation of Radioactive Waste in Concrete

g

\begin{tabular}{|c|c|c|c|c|c|c|c|c|c|}
\hline $\begin{array}{l}\text { Di ame ter } \\
\text { (m) }\end{array}$ & $\begin{array}{l}\text { Canister } \\
\text { Vol ume } \\
\text { (L) }\end{array}$ & $\begin{array}{c}\text { Thermal } \\
\text { Conduct } \\
\left(\mathrm{W} / \mathrm{m}^{\circ} \mathrm{C}\right)\end{array}$ & $\begin{array}{c}\text { Volumetric } \\
\text { Heat } \\
\text { Generation } \\
\text { (W/L) } \\
\end{array}$ & $\begin{array}{r}\text { Number of } \\
\text { Requi } \\
\end{array}$ & $\begin{array}{l}\text { Canisters } \\
\mathrm{d}^{\mathrm{a}}\end{array}$ & $\begin{array}{l}\text { Volume of } \\
\text { Waste per } \\
\text { Canisterb } \\
\text { (L) } \\
\end{array}$ & $\begin{array}{l}\text { Volume of } \\
\text { Cement per } \\
\text { Canister } \\
\text { (L) } \\
\end{array}$ & $\begin{array}{c}\text { Annual } \\
\text { Cement } \\
\text { Volume } \\
\left(\mathrm{m}^{3}\right) \\
\end{array}$ & $\begin{array}{l}\text { Annual } \\
\text { Canister } \\
\text { Weightc } \\
\text { (t) }\end{array}$ \\
\hline \multirow[t]{3}{*}{0.5} & 589.0 & 0.2 & 1.255 & 18667 & 62.22 & 3.21 & 585.83 & 10936 & 847.2 \\
\hline & & 0.6 & 3.765 & 6222 & 20.74 & 9.64 & 579.41 & 3605 & 282.4 \\
\hline & & 1.0 & 6.275 & 3733 & 12.44 & 16.07 & 572.98 & 2139 & 169.4 \\
\hline \multirow[t]{3}{*}{0.4} & 377.0 & 0.2 & 1.803 & 20302 & 67.68 & 2.96 & 374.04 & 7594 & 725.8 \\
\hline & & 0.6 & 5.408 & 6769 & 22.56 & 8.86 & 368.13 & 2492 & 242.0 \\
\hline & & 1.0 & 9.015 & 4061 & 13.54 & 14.78 & 362.21 & 1471 & 145.2 \\
\hline \multirow[t]{3}{*}{0.3} & 212.1 & 0.2 & 2.833 & 22971 & 76.57 & 2.61 & 209.45 & 4811 & 606.3 \\
\hline & & 0.6 & 8.499 & 7657 & 25.52 & 7.84 & 204.22 & 1564 & 202.1 \\
\hline & & 1.0 & 14.165 & 4594 & 15.31 & 13.06 & 199.00 & 914 & 121.3 \\
\hline \multirow[t]{3}{*}{0.2} & 94.3 & 0.2 & 5.195 & 28185 & 93.95 & 2.13 & 92.12 & 2596 & 488.1 \\
\hline & & 0.6 & 15.585 & 9395 & 31.32 & 6.39 & 87.86 & 825 & 162.7 \\
\hline & & 1.0 & 25.975 & 5637 & 18.79 & 10.64 & 83.60 & 471 & 97.6 \\
\hline \multirow[t]{3}{*}{0.1} & 23.6 & 0.2 & 13.496 & 43397 & 144.66 & 1.38 & 22.18 & 963 & 369.7 \\
\hline & & 0.6 & 40.488 & 14466 & 48.22 & 4.15 & 19.41 & 280 & 123.2 \\
\hline & & 1.0 & 67.480 & 8679 & 28.93 & 6.91 & 16.65 & 145 & 73.9 \\
\hline
\end{tabular}

a. Based on $200^{\circ} \mathrm{C}$ centerline temperature

b. Based on $40 \mathrm{~L} / \mathrm{MTU}$

c. Based on total canister material; canister is $3 \mathrm{~m}$ long with $1.27 \mathrm{~cm}$ wall thickness 
TABLE 16. Material Requirements for the Incorporation of Radioactive Waste in Concrete

9

\begin{tabular}{|c|c|c|c|c|c|c|c|c|c|}
\hline $\begin{array}{l}\text { Diame ter } \\
-(\text { m) }\end{array}$ & $\begin{array}{c}\text { Canister } \\
\text { Volume } \\
\text { (LL) }\end{array}$ & $\begin{array}{l}\text { Thermal } \\
\text { Conductivity } \\
\left(\mathrm{W} / \mathrm{m}^{\circ} \mathrm{C}\right) \\
\end{array}$ & $\begin{array}{l}\text { Volumetric } \\
\text { Heat } \\
\text { Generation } \\
\text { (W/L) }\end{array}$ & $\begin{array}{r}\text { Number of } \\
\text { Requi }\end{array}$ & $\begin{array}{l}\text { Canisters } \\
e^{d^{d}}\end{array}$ & $\begin{array}{l}\text { Volunie of } \\
\text { Waste per } \\
\text { Canisterb } \\
\text { (L) }\end{array}$ & $\begin{array}{l}\text { Vulune of } \\
\text { Cemient per } \\
\text { Canister } \\
\text { (L) }\end{array}$ & $\begin{array}{c}\text { Annual } \\
\text { Cement } \\
\text { Volume } \\
\left(m^{3}\right) \\
\end{array}$ & $\begin{array}{l}\text { Annual } \\
\text { Canister } \\
\text { Weighte } \\
\text { - } t \text { t } 1\end{array}$ \\
\hline \multirow[t]{3}{*}{0.5} & 589.0 & 0.2 & 2.10 & 150 & 37.17 & 5.38 & 583.76 & 6508 & 506.1 \\
\hline & & 0.6 & 6.30 & 3717 & 12.39 & 16.14 & 572.91 & 2129 & 168.7 \\
\hline & & 1.0 & 10.51 & 2230 & 7.43 & 26.90 & 562.14 & 1254 & 101.2 \\
\hline \multirow[t]{3}{*}{0.4} & 377.0 & 0.2 & 3.04 & 12049 & 40.16 & 4.98 & 372.01 & 4482 & 430.7 \\
\hline & & 0.6 & 9.11 & 4016 & 13.39 & 14.94 & 362.05 & 1454 & 143.6 \\
\hline & & 1.0 & 15.19 & 2409 & 8.03 & 24.90 & 352.09 & 848 & 86.1 \\
\hline \multirow[t]{3}{*}{0.3} & 212.1 & 0.2 & 4.82 & 13507 & 45.02 & 4.44 & 207.62 & 2804 & 356.5 \\
\hline & & 0.6 & 14.45 & 4502 & 15.01 & 13.33 & 198.73 & 895 & 118.8 \\
\hline & & 1.0 & 24.09 & 2701 & 9.01 & 22.21 & 189.85 & 513 & 71.3 \\
\hline \multirow[t]{3}{*}{0.2} & 94.3 & 0.2 & 8.96 & 16345 & 54.49 & 3.67 & 90.58 & 1481 & 283.0 \\
\hline & & 0.6 & 26.87 & 5448 & 18.16 & 11.01 & 83.24 & 454 & 94.3 \\
\hline & & 1.0 & 44.79 & 3269 & 10.90 & 18.35 & 75.89 & 248 & 56.6 \\
\hline \multirow[t]{3}{*}{0.1} & 23.6 & 0.2 & 23.81 & 24601 & 82.00 & 2.44 & 21.12 & 520 & 209.6 \\
\hline & & 0.6 & 71.42 & 8200 & 27.33 & 7.32 & 16.25 & 133 & 69.9 \\
\hline & & 1.0 & 119.04 & 4920 & 16.40 & 12.19 & 11.37 & 56 & 41.9 \\
\hline
\end{tabular}

a. Based on $300^{\circ} \mathrm{C}$ centerl ine teniperature

b. Based on 40 L/MTU

c. Based on total canister material; canister is 3 in long with $1.27 \mathrm{~cm}$ wall thickness 


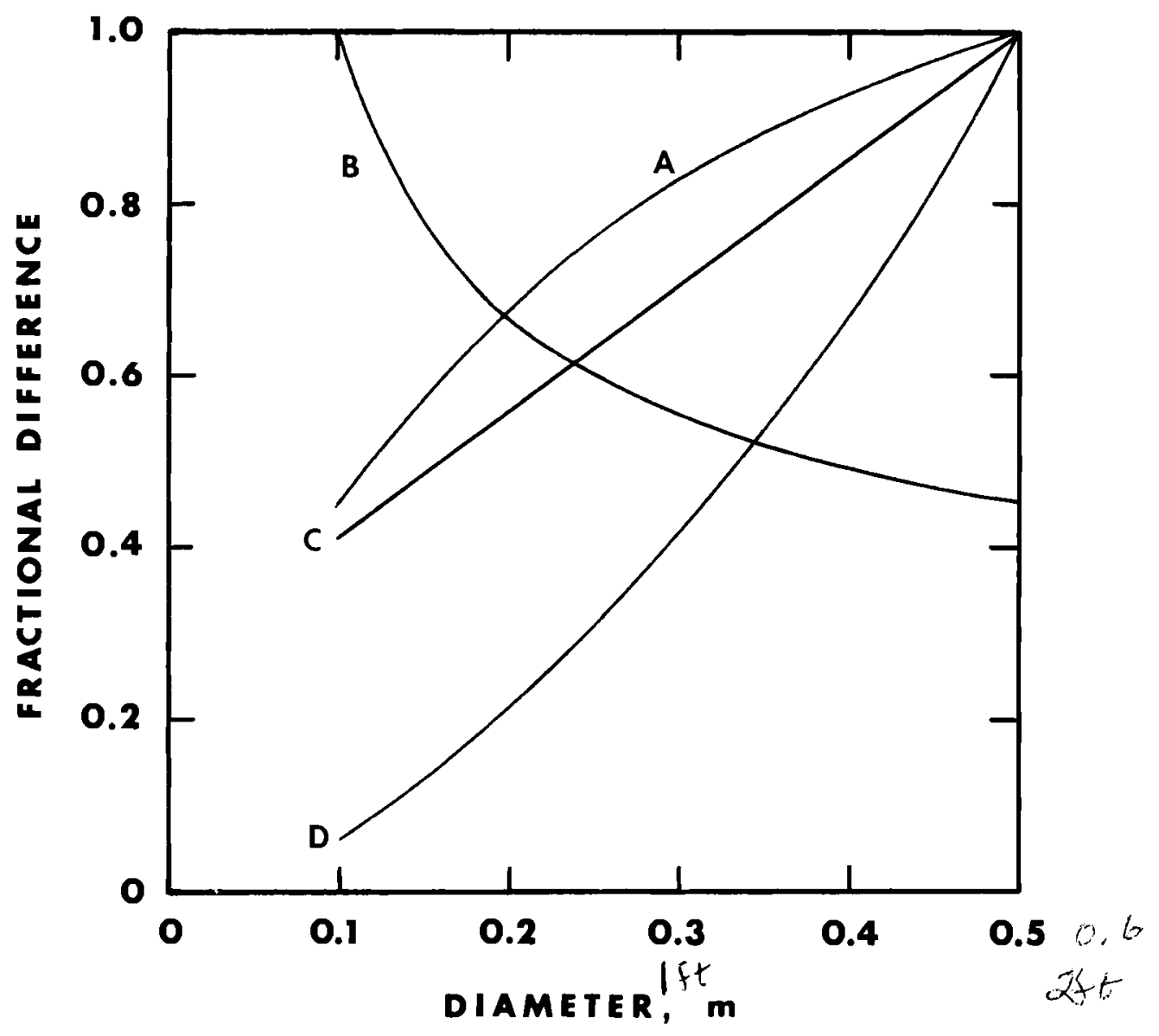
A - Waste per canister
B - Number of canisters
C - Canister weight
D - Cement weight

FIGURE 4. Fractional Change in Waste Loading Requirements as a Function of Canister Diameter 
TABLE 17. Canister Centerline Temperatures as a Function of Diameter and Thermal Conductivity

Centerline Temperature $\left({ }^{\circ} \mathrm{C}\right)$

$$
Q=10000 \mathrm{~W} / \mathrm{m}^{3}
$$

Diameter

(m)

Thermal Conductivity $\left(\mathrm{W} / \mathrm{m}^{\circ} \mathrm{C}\right)$

\begin{tabular}{|c|c|c|c|c|}
\hline 0.2 & 0.4 & 0.6 & 0.8 & 1.0 \\
\hline 1153 & 624 & 440 & 346 & 288 \\
\hline 819 & 452 & 323 & 257 & 216 \\
\hline 544 & 309 & 226 & 183 & 156 \\
\hline 327 & 195 & 147 & 122 & 106 \\
\hline 163 & 106 & 85 & 74 & 67 \\
\hline
\end{tabular}

0.

0.

0.3

0.2

0.1

$163 \quad 106$

85

67

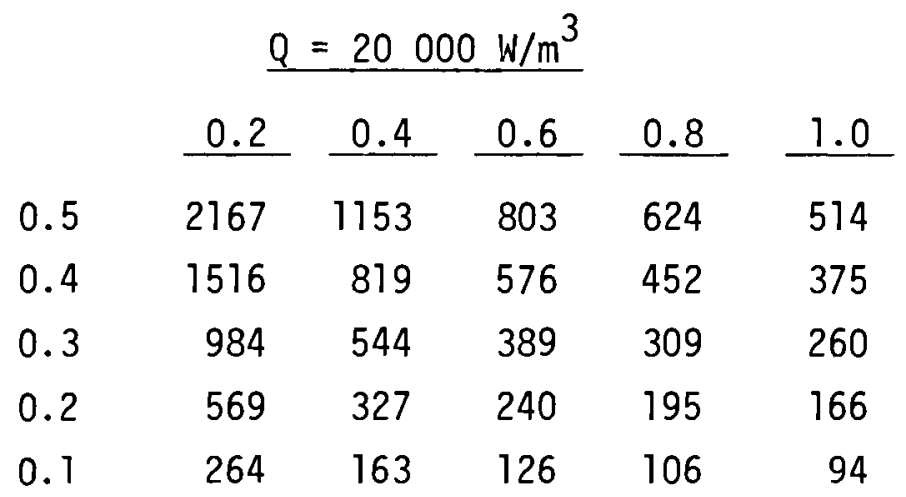

\begin{tabular}{|c|c|c|c|c|c|}
\hline \multicolumn{6}{|c|}{$Q=50000 \mathrm{~W} / \mathrm{m}^{3}$} \\
\hline & 0.2 & 0.4 & 0.6 & 0.8 & 1.0 \\
\hline 0.5 & 5078 & 2662 & 1833 & 1410 & 1153 \\
\hline 0.4 & 3495 & 1854 & 1287 & 996 & 819 \\
\hline 0.3 & 2214 & 1196 & 840 & 657 & 544 \\
\hline 0.2 & 1229 & 684 & 490 & 389 & 327 \\
\hline 0.1 & 528 & 311 & 232 & 190 & 163 \\
\hline
\end{tabular}


TABLE 18. Canister Centerline Temperature as a Function of Diameter and Volumetric Heat Generation

Centerline Temperature $\left({ }^{\prime} \mathrm{C}\right)$

$$
\underline{k}=1.0 \mathrm{~W} / \mathrm{m}^{\circ} \mathrm{C}
$$

Diameter

(m)

Heat Generation, Q (W/L)

$100 \quad 80 \quad 60 \quad 40 \quad 20 \quad 15 \quad 10 \quad 5$

$\begin{array}{lllllllll}0.5 & 2167 & 1766 & 1359 & 944 & 51< & 403 & 288 & 169\end{array}$

$\begin{array}{lllllllll}0.4 & 1516 & 1241 & 961 & 674 & 375 & 297 & 216 & 131\end{array}$

$\begin{array}{lllllllll}0.3 & 984 & 811 & 634 & 452 & 260 & 209 & 156 & 100\end{array}$

$\begin{array}{lllllllll}0.2 & 569 & 474 & 377 & 275 & 166 & 137 & 106 & 73\end{array}$

$\begin{array}{lllllllll}0.1 & 264 & 225 & 185 & 141 & 94 & 81 & 67 & 51\end{array}$

$\underline{k}=0.5 \mathrm{~W} / \mathrm{m}^{\circ} \mathrm{C}$

$100 \quad 80 \quad \underline{60} \quad \underline{40} \quad 20 \quad \underline{15} \quad \underline{10} \quad \underline{\square}$

$\begin{array}{lllllllll}0.5 & 4120 & 3347 & 2563 & 1766 & 944 & 731 & 514 & 288\end{array}$

$\begin{array}{lllllllll}0.4 & 2847 & 2321 & 1787 & 1241 & 674 & 527 & 375 & 216\end{array}$

$\begin{array}{lllllllll}0.3 & 1813 & 1487 & 1154 & 811 & 452 & 357 & 260 & 156\end{array}$

$\begin{array}{lllllllll}0.2 & 1016 & 841 & 661 & 474 & 275 & 222 & 166 & 106\end{array}$

$\begin{array}{lllllllll}0.1 & 444 & 374 & 302 & 225 & 141 & 118 & 94 & 67\end{array}$ 


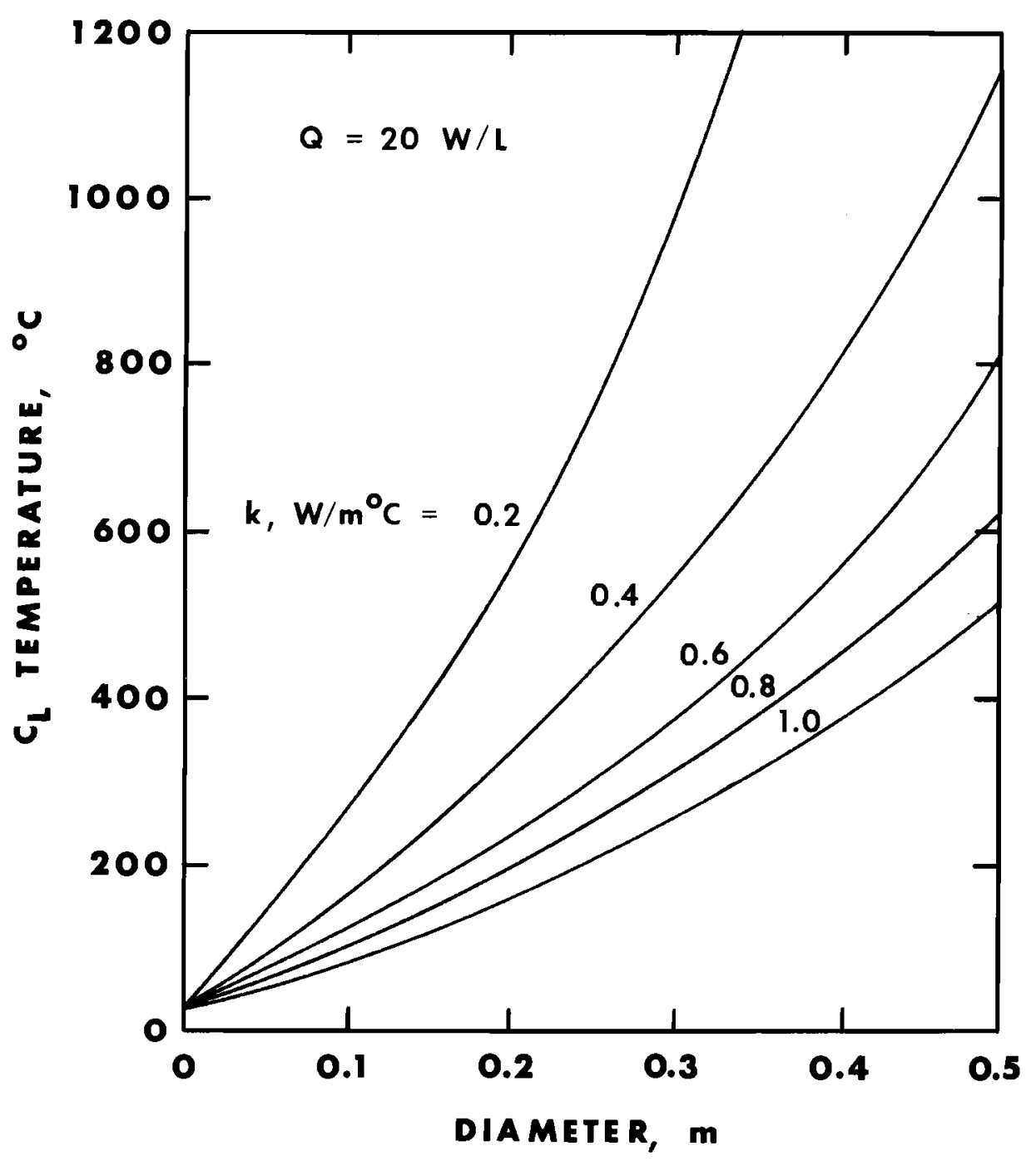

FIGURE 5. Canister Centerline Temperature as a Function of Diameter and Thermal Conductivity 


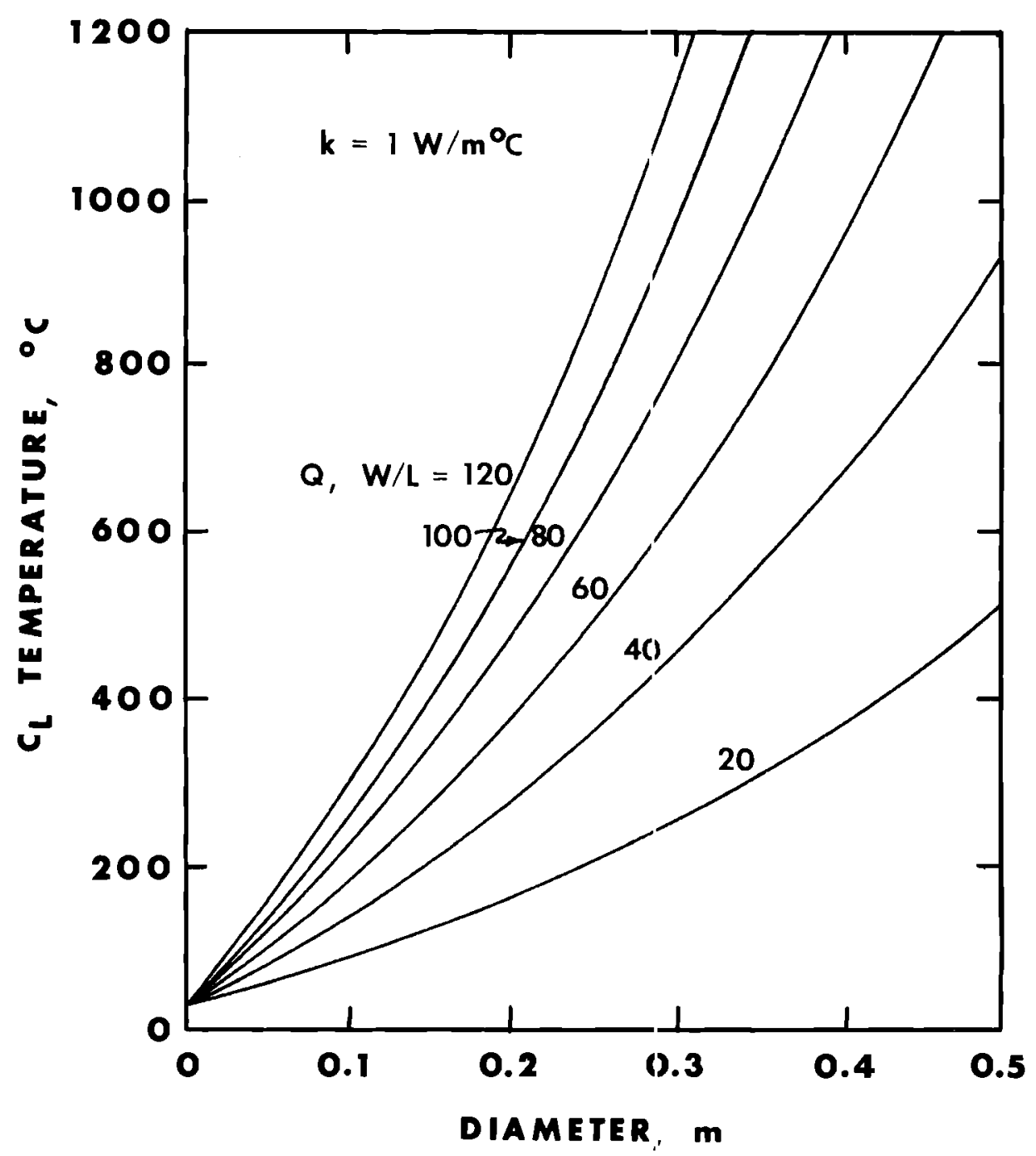

FIGURE 6. Canister Centerline Temperature as a Function of Diameter and Volumetric Heat lieneration 


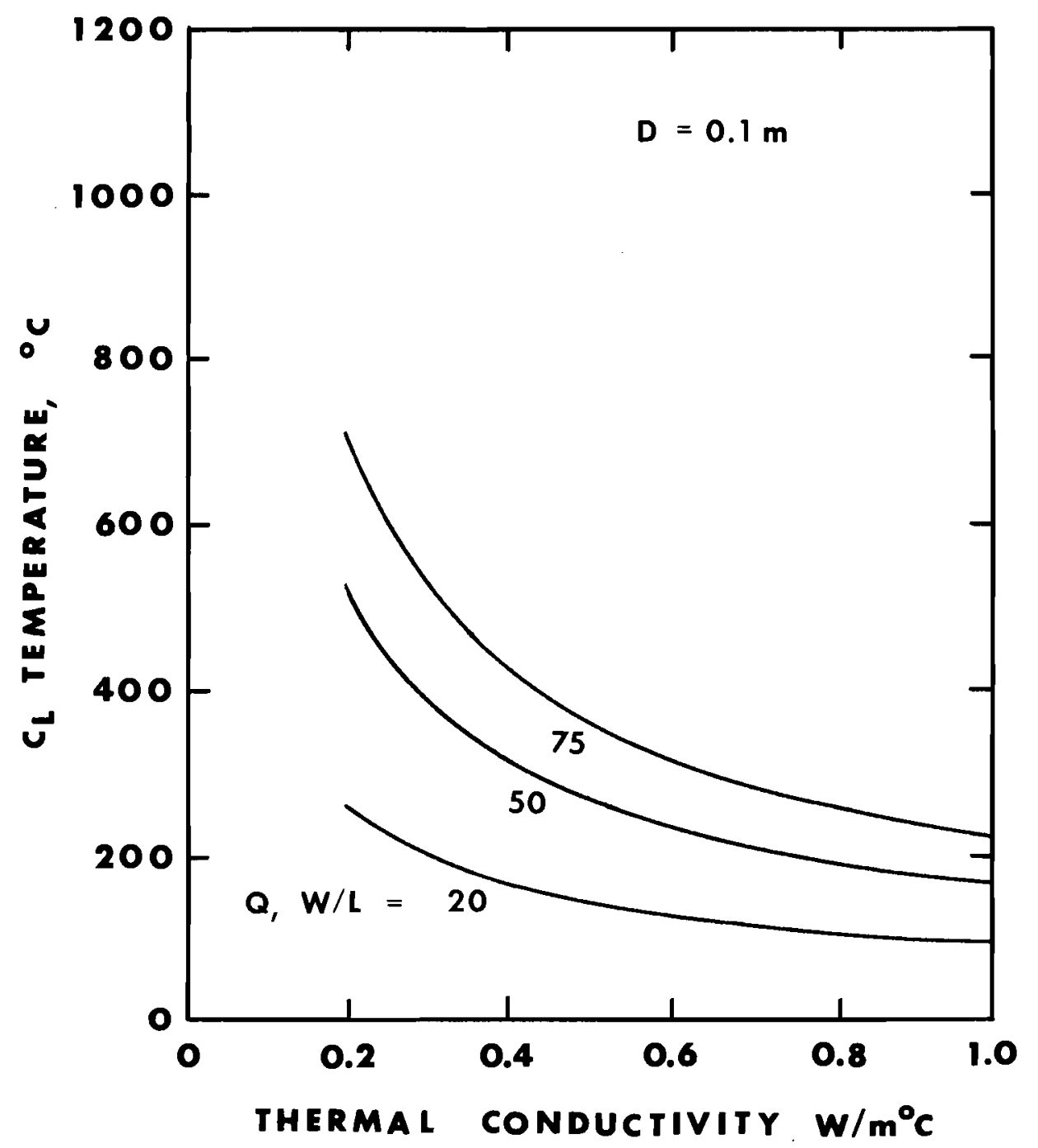

FIGURE 7. Canister Centerline Temperature as a Function of Thermal Conductivity and Volumetric Heat Generation 


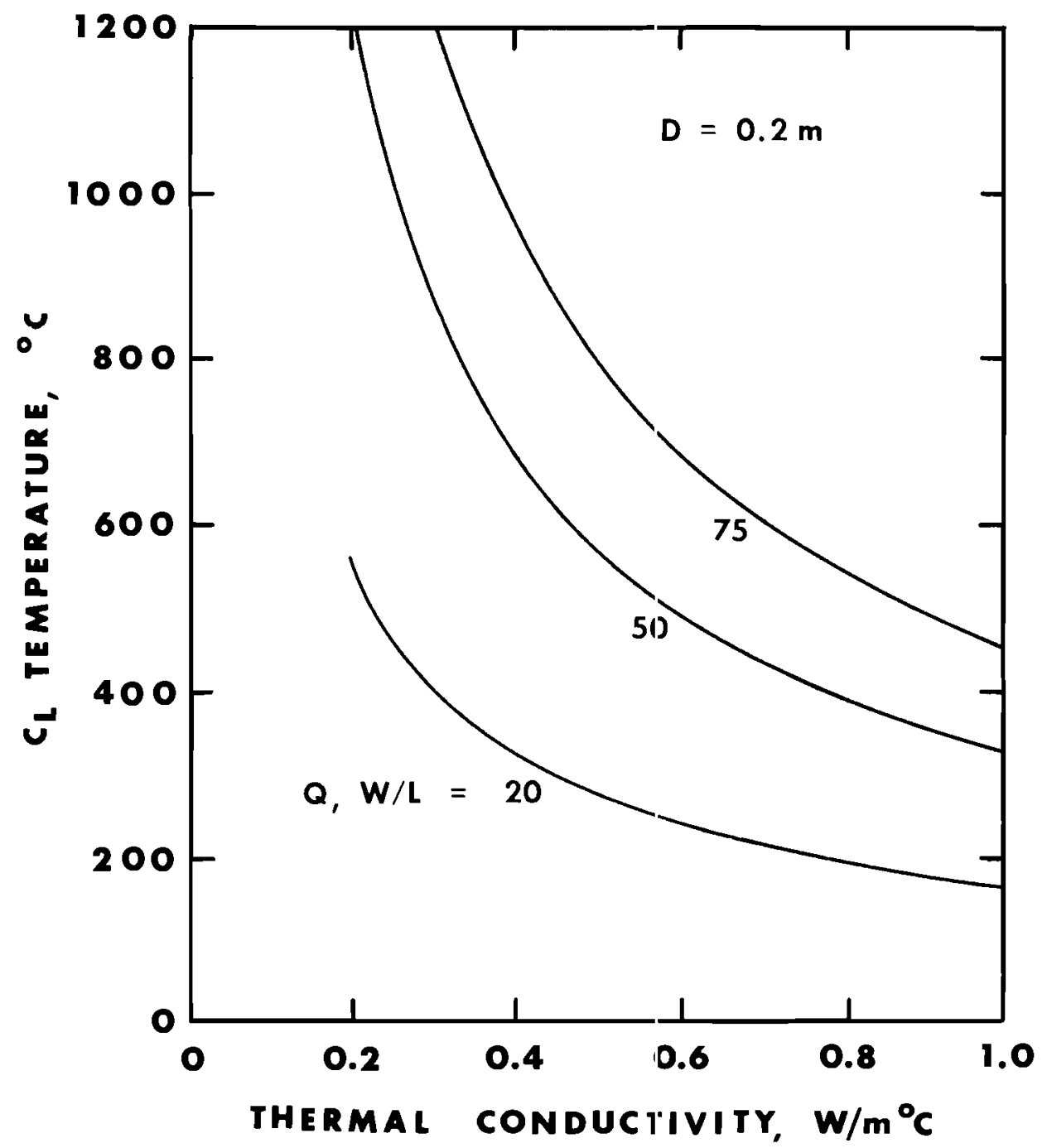

FIGURE 8. Canister Centerline Temperature as a Function of Thermal Conductivity and Volumetric Heat Generation 


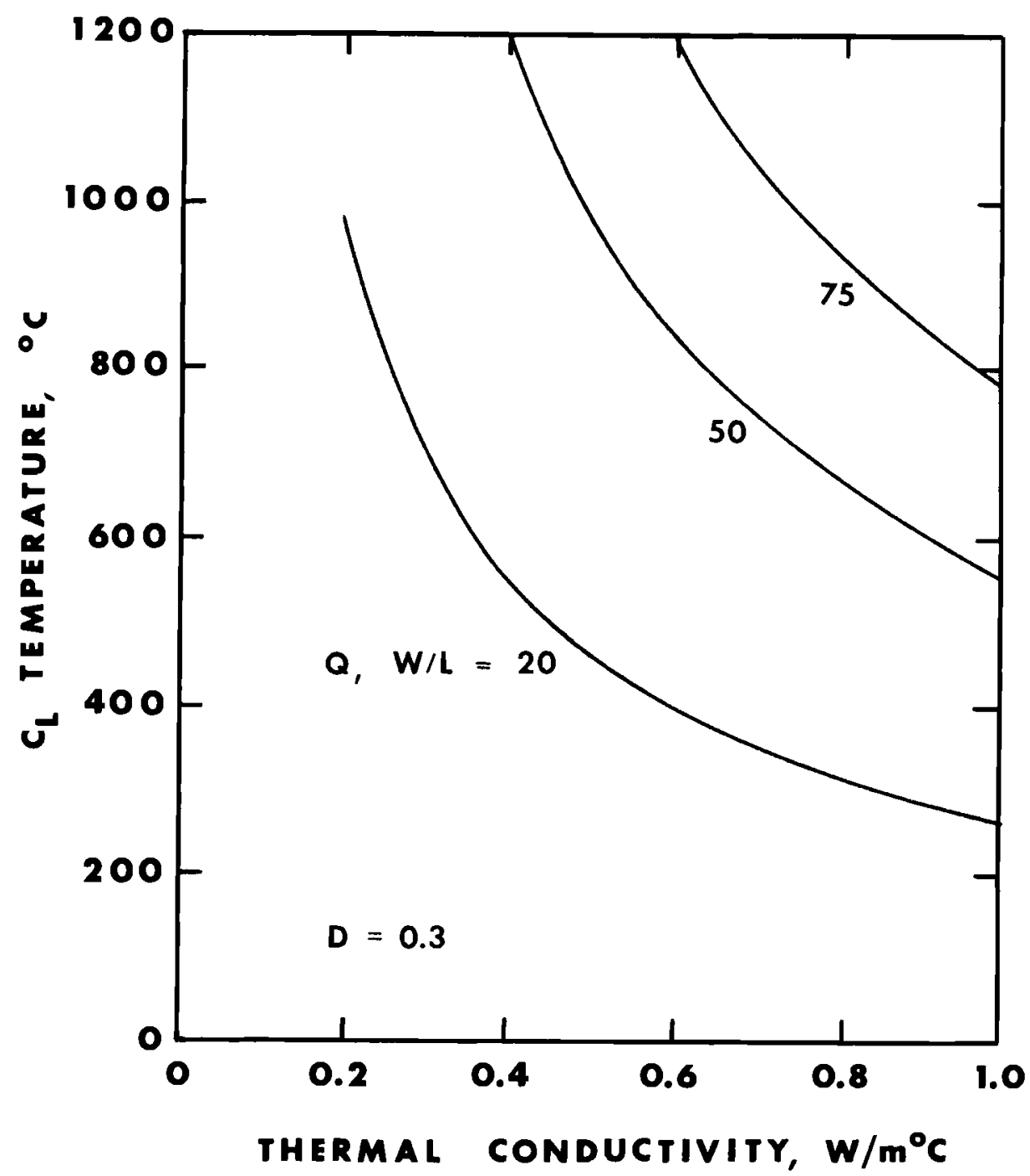

FIGURE 9. Canister Centerline Temperature as a Function of Thermal Conductivity and Volumetric Heat Generation 


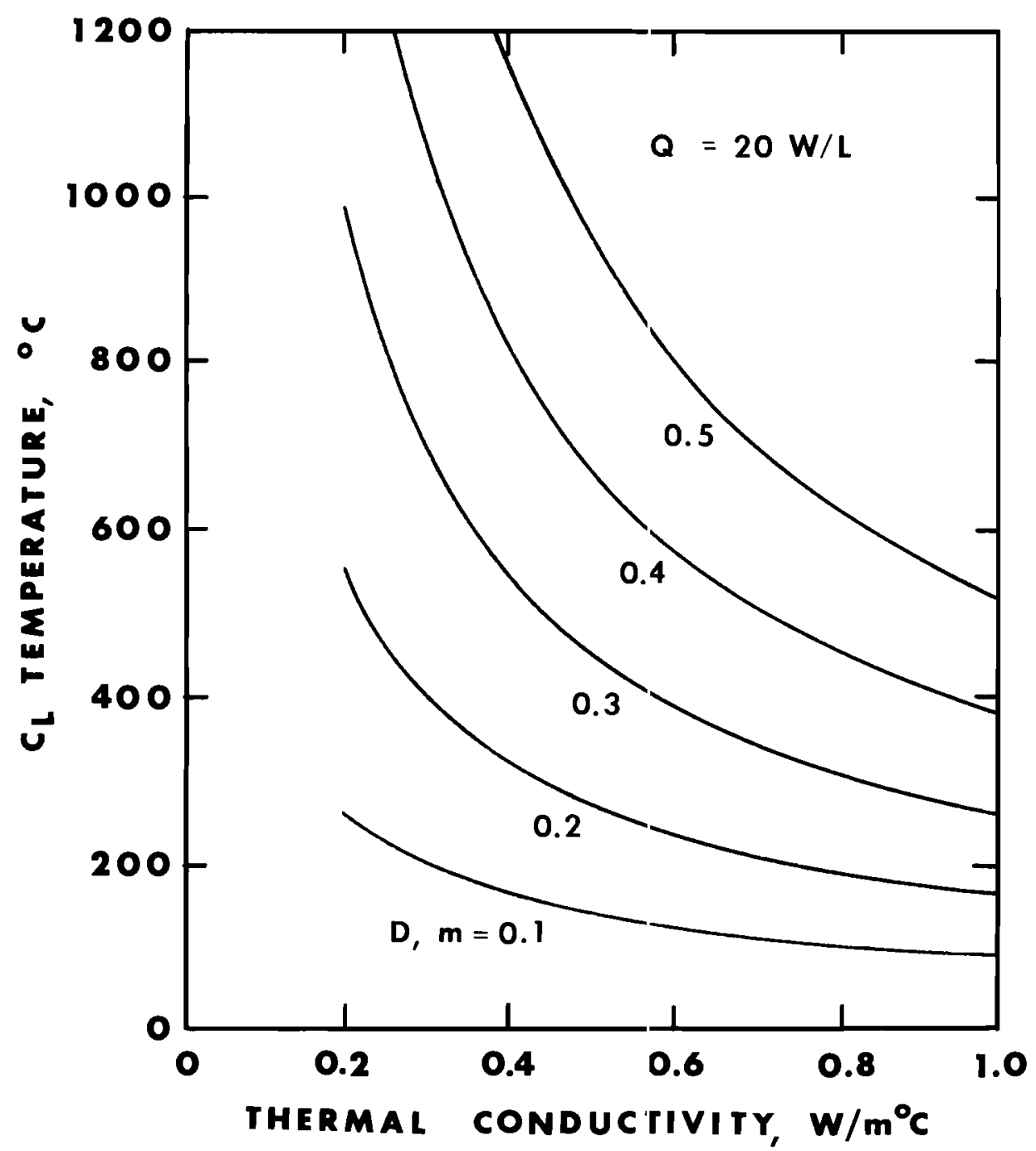

FIfURE 10. Canister Centerline Temperature as a Function of Thermal Conductivity and Diameter 


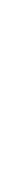




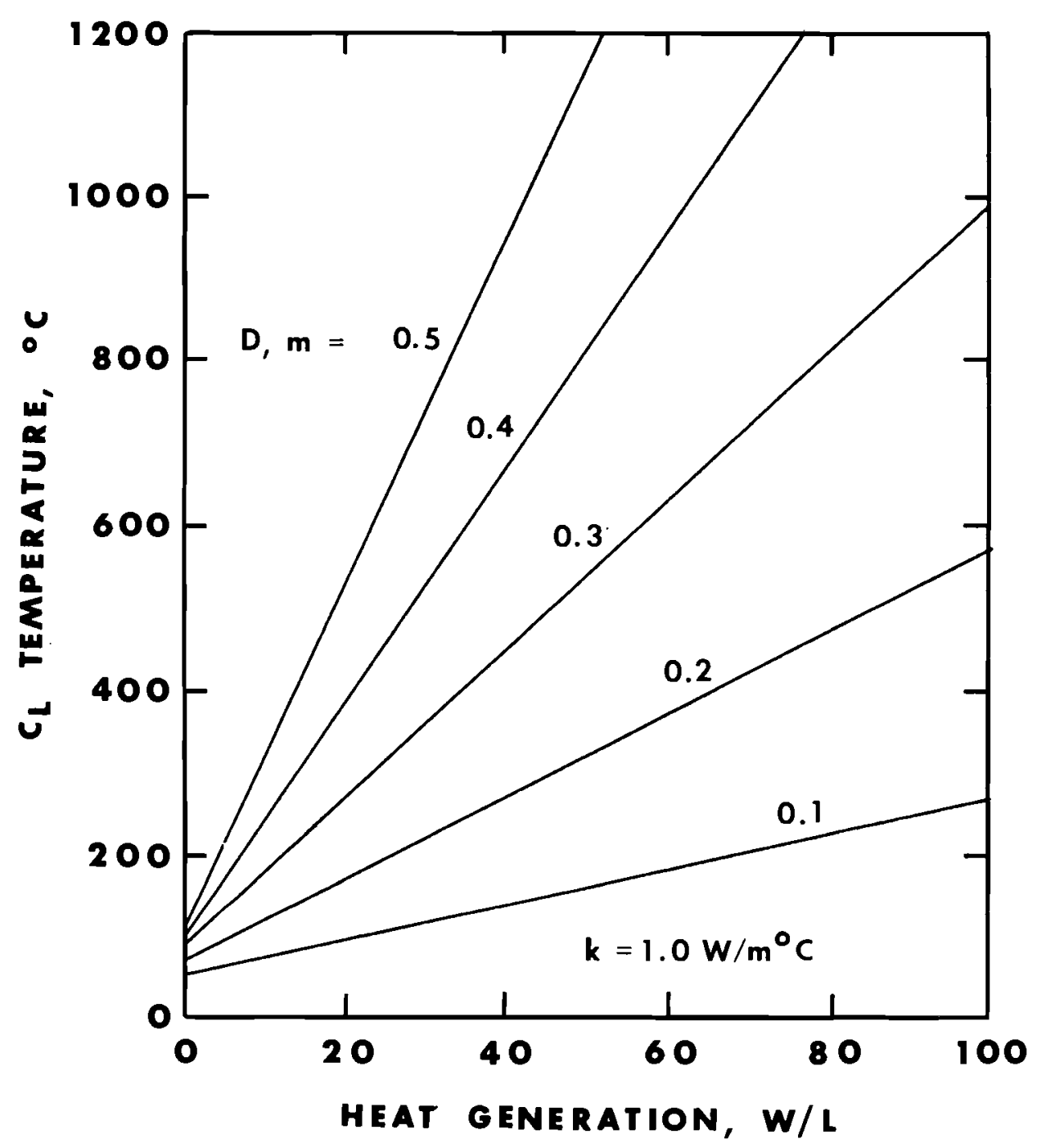

FIGURE 12. Canister Centerline Temperature as a Function of Volumetric Heat Generation and Diameter 
TABLE 19. Maximum Diameter for Various Temperatures as a Function of Thermal Conductivity

$$
\begin{aligned}
& \text { Maximum Diameter (m) } \\
& Q Q=50000 \mathrm{~W} / \mathrm{m}^{3}
\end{aligned}
$$

Temperature

$\left({ }^{\circ} \mathrm{C}\right)$

100

200

300

400

500

100

200

300

400

500

100

200

300

400

500

Thermal Conductivity $\left(\mathrm{W} / \mathrm{m}^{\circ} \mathrm{C}\right)$

\begin{tabular}{llllll}
0.2 & 0.4 & 0.6 & 0.8 & 1.0 \\
\hline 0.0118 & 0.0225 & 0.0326 & 0.0423 & 0.0514 \\
0.0340 & 0.0615 & 0.0850 & 0.1063 & 0.1254 \\
0.0562 & 0.0965 & 0.1300 & 0.1593 & 0.1858 \\
0.0764 & 0.1275 & 0.1688 & 0.2042 & 0.2368 \\
0.0952 & 0.1551 & 0.2034 & 0.2449 & 0.2818
\end{tabular}
$Q=25000 \mathrm{~W} / \mathrm{m}^{3}$

$\begin{array}{lllll}0.2 & 0.4 & 0.6 & 0.8 & 1.0\end{array}$

$\begin{array}{lllll}0.0224 & 0.0423 & 0.0600 & 0.0771 & 0.0918\end{array}$

$\begin{array}{llllll}0.0614 & 0.1062 & 0.1434 & 0.1759 & 0.2058\end{array}$

$\begin{array}{lllll}0.0964 & 0.1592 & 0.2100 & 0.2539 & 0.2930\end{array}$

$\begin{array}{llllll}0.1274 & 0.2041 & 0.2662 & 0.3191 & 0.3662\end{array}$

$\begin{array}{lllll}0.1550 & 0.2448 & 0.3155 & 0.3761 & 0.4302\end{array}$

$$
Q=15000 \mathrm{~W} / \mathrm{m}^{3}
$$

$\begin{array}{lllll}0.2 & 0.4 & 0.6 & 0.8 & 1.0\end{array}$

$$
\begin{array}{llllll}
0.0360 & 0.0656 & 0.0918 & 0.1156 & 0.1379
\end{array}
$$

$\begin{array}{llllll}0.0922 & 0.1546 & 0.2058 & 0.2496 & 0.2899\end{array}$

$\begin{array}{lllll}0.1402 & 0.2252 & 0.2930 & 0.3512 & 0.4031\end{array}$

$\begin{array}{lllll}0.1814 & 0.2852 & 0.3662 & 0.4360 & 0.4979\end{array}$

$\begin{array}{llllll}0.2178 & 0.3368 & 0.4302 & 0.5096 & 0.5803\end{array}$


TABLE 20. Maximum Allowable Volumetric Heat

Generation as a Function of Diameter and Thermal Conductivity

Maximum Allowable Volumetric Heat Generation $\left(\mathrm{W} / \mathrm{m}^{3}\right)$

$C_{L}$ Temperature $=100^{\circ} \mathrm{C}$

Diameter (m) Thermal Conductivity $\left(\mathrm{W} / \mathrm{m}^{\circ} \mathrm{C}\right)$

\begin{tabular}{|c|c|c|c|c|}
\hline 0.2 & 0.4 & 0.6 & 0.8 & 1.0 \\
\hline 462 & 924 & 1386 & 1848 & 2310 \\
\hline 654 & 1308 & 1962 & 2616 & 3270 \\
\hline 1010 & 2020 & 3030 & 4040 & 5050 \\
\hline 1802 & 3604 & 5406 & 7208 & 9010 \\
\hline 4488 & 8976 & 13464 & 17952 & 22440 \\
\hline
\end{tabular}

$C_{L}$ Temperature $=300^{\circ} \mathrm{C}$

$\begin{array}{lllll}0.2 & 0.4 & 0.6 & 0.8 & 1.0\end{array}$

$\begin{array}{lllllllll}0.5 & 2 & 101 & 4 & 202 & 6 & 303 & 8404 & 10505\end{array}$

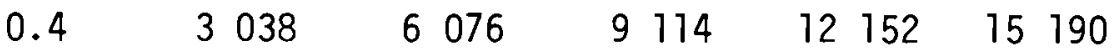

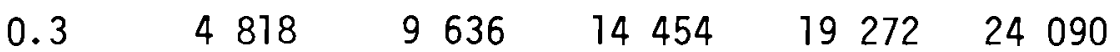

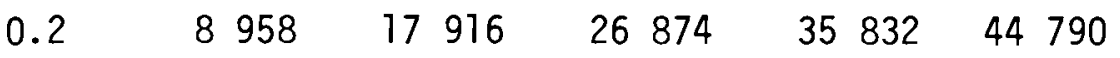

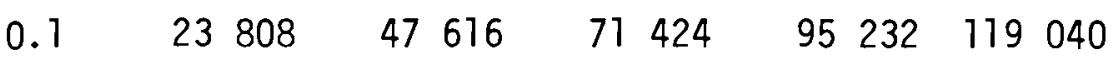

$C_{L}$ Temperature $=500^{\circ} \mathrm{C}$

$\begin{array}{lllll}0.2 & 0.4 & 0.6 & 0.8 & 1.0\end{array}$

$\begin{array}{lllllllll}0.5 & 3872 & 7744 & 11 & 616 & 15 & 488 & 19360\end{array}$

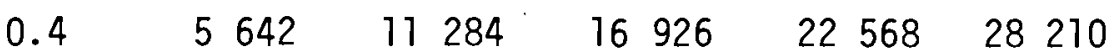

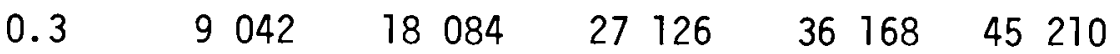

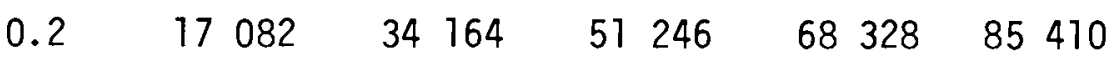

$\begin{array}{lllllllllll}0.1 & 46 & 628 & 93 & 256 & 139 & 884 & 186 & 512 & 233 & 140\end{array}$ 


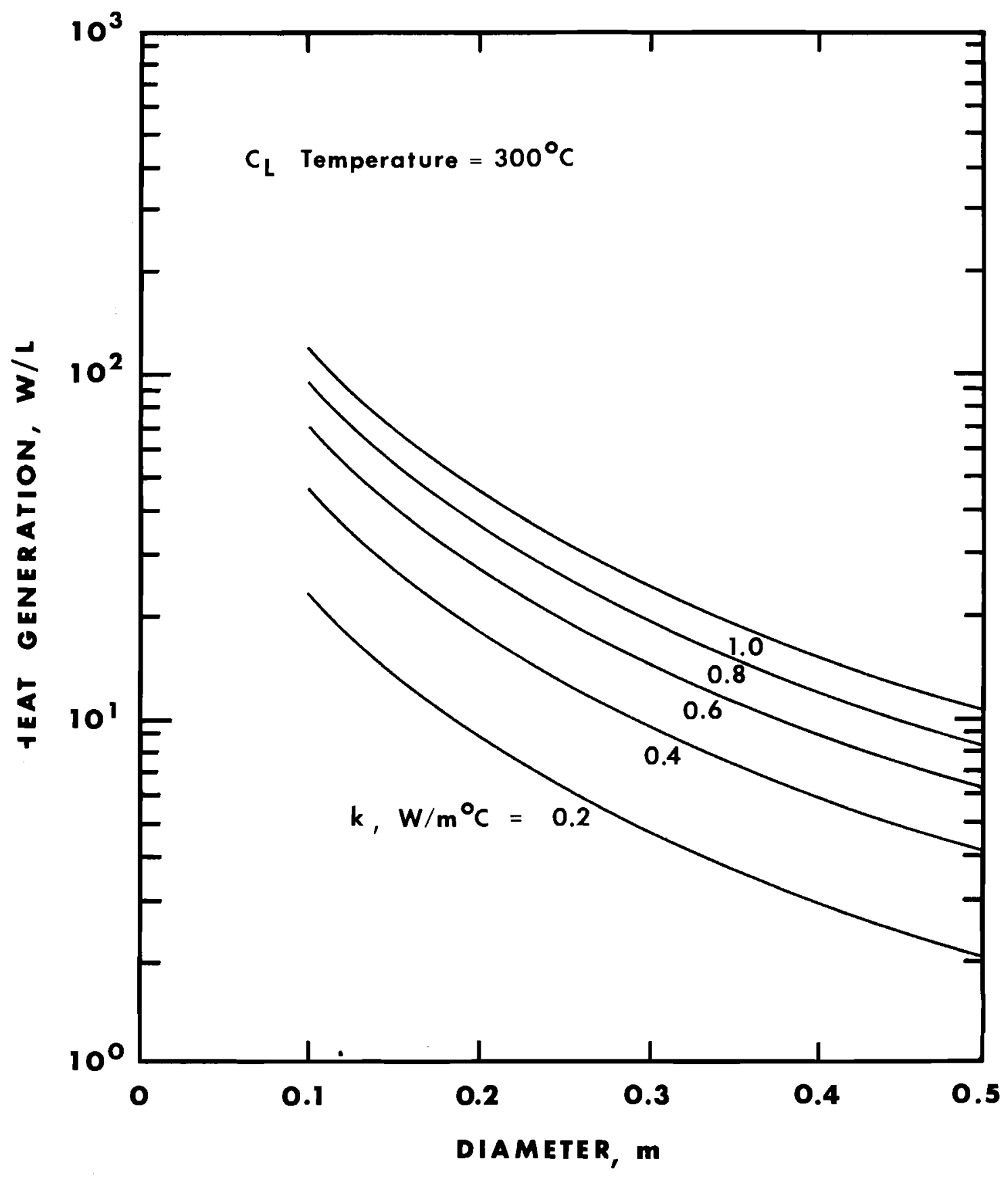

FIGURE 13. Volumetric Heat Generation as a Function of Diameter and Thermal Conductivity 


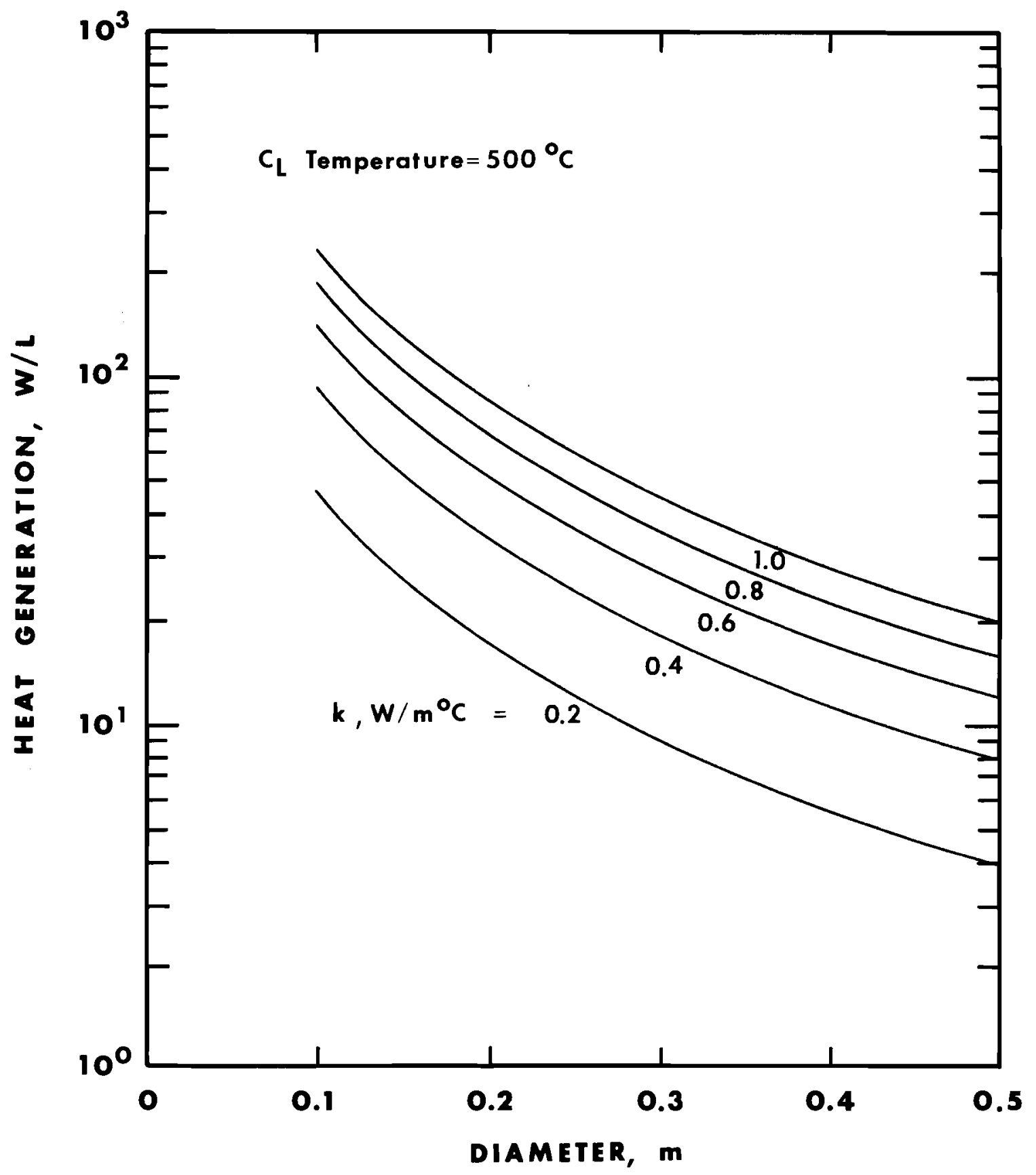

FIGURE 14. Volumetric Heat Generation as a Function of Diameter and Thermal Conductivity 
TABLE 21. Number of Canisters Required to Encapsulate 1500 MTU Waste as a Function of Diameter and Thermal Conductivity

Number of Canisters Required per Year $Q=9.2 \mathrm{~kW} / \mathrm{MTU}$

$$
C_{L} \text { Temperature }=300^{\circ} \mathrm{C}
$$

Diameter

Thermal Conductivity $\left(\mathrm{W} / \mathrm{m}^{\circ} \mathrm{C}\right)$

\begin{tabular}{|c|c|c|c|c|}
\hline 2 & 0.4 & 0.6 & 0.8 & 1.0 \\
\hline 070 & 5535 & 3690 & 2767 & 221 \\
\hline & 5981 & 3987 & 2990 & 235 \\
\hline & 6705 & 4470 & 3352 & 268 \\
\hline & 8114 & 5409 & $\begin{array}{lll}4057\end{array}$ & 24 \\
\hline & 2211 & $\begin{array}{lll}8 & 141\end{array}$ & 6106 & 488 \\
\hline
\end{tabular}

$C_{L}$ Temperature $=500^{\circ} \mathrm{C}$

$\begin{array}{rrrrrr}0.5 & 11070 & 5535 & 3690 \\ 0.4 & 11962 & 5981 & 3987 \\ 0.3 & 13409 & 6705 & 4470 \\ 0.2 & 16227 & 8114 & 5409 \\ 0.1 & 24 & 422 & 12211 & 8141 \\ & \text { CL L } \text { Temperature }=500^{\circ} \mathrm{C}\end{array}$

\begin{tabular}{|c|c|c|c|c|c|}
\hline & 0.2 & 0.4 & 0.6 & 0.8 & 1.0 \\
\hline 0.5 & 6007 & 3003 & 2002 & 1502 & 1201 \\
\hline 0.4 & 6441 & 3221 & 2147 & 1610 & 1288 \\
\hline 0.3 & 7145 & 3573 & 2382 & 1786 & 1429 \\
\hline 0.2 & 8510 & 4255 & 2837 & 2127 & 1702 \\
\hline .1 & 12470 & 6235 & 4157 & 3117 & 2494 \\
\hline
\end{tabular}

$C_{L}$ Temperature $=800^{\circ} \mathrm{C}$

\begin{tabular}{|c|c|c|c|c|c|}
\hline & 0.2 & 0.4 & 0.6 & 0.8 & 1.0 \\
\hline 0.5 & 3502 & 1751 & 1167 & 875 & 700 \\
\hline .4 & 3731 & 1866 & 1244 & 933 & 746 \\
\hline 3 & $4 \quad 102$ & 2051 & 1367 & 1026 & 820 \\
\hline & 4818 & 2409 & 1606 & 1205 & 964 \\
\hline & 6880 & 3440 & 2293 & 1720 & 1376 \\
\hline
\end{tabular}




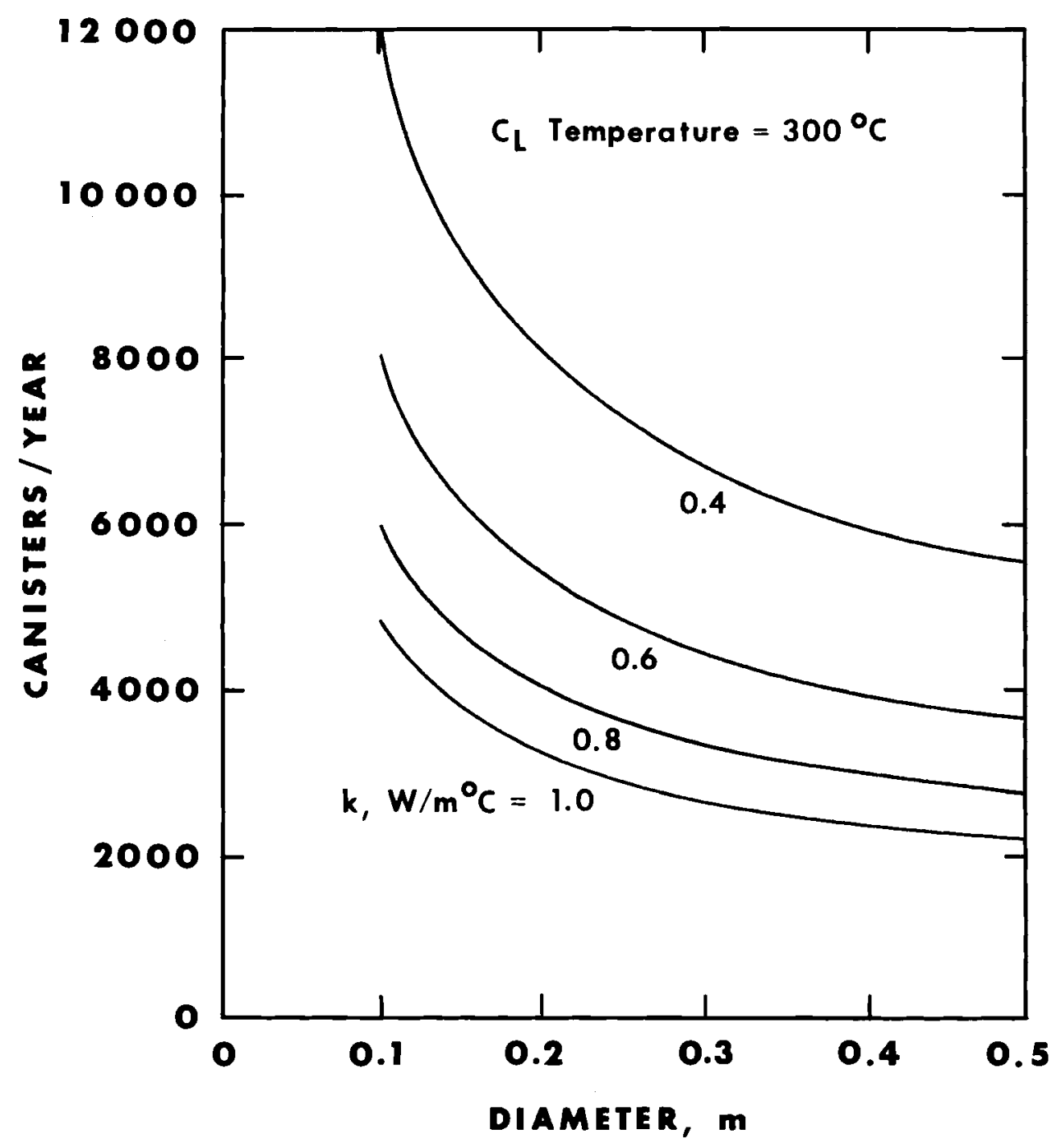

FIGURE 15. Number of Canisters Required per Year as a Function of Diameter and Thermal Conductivity 


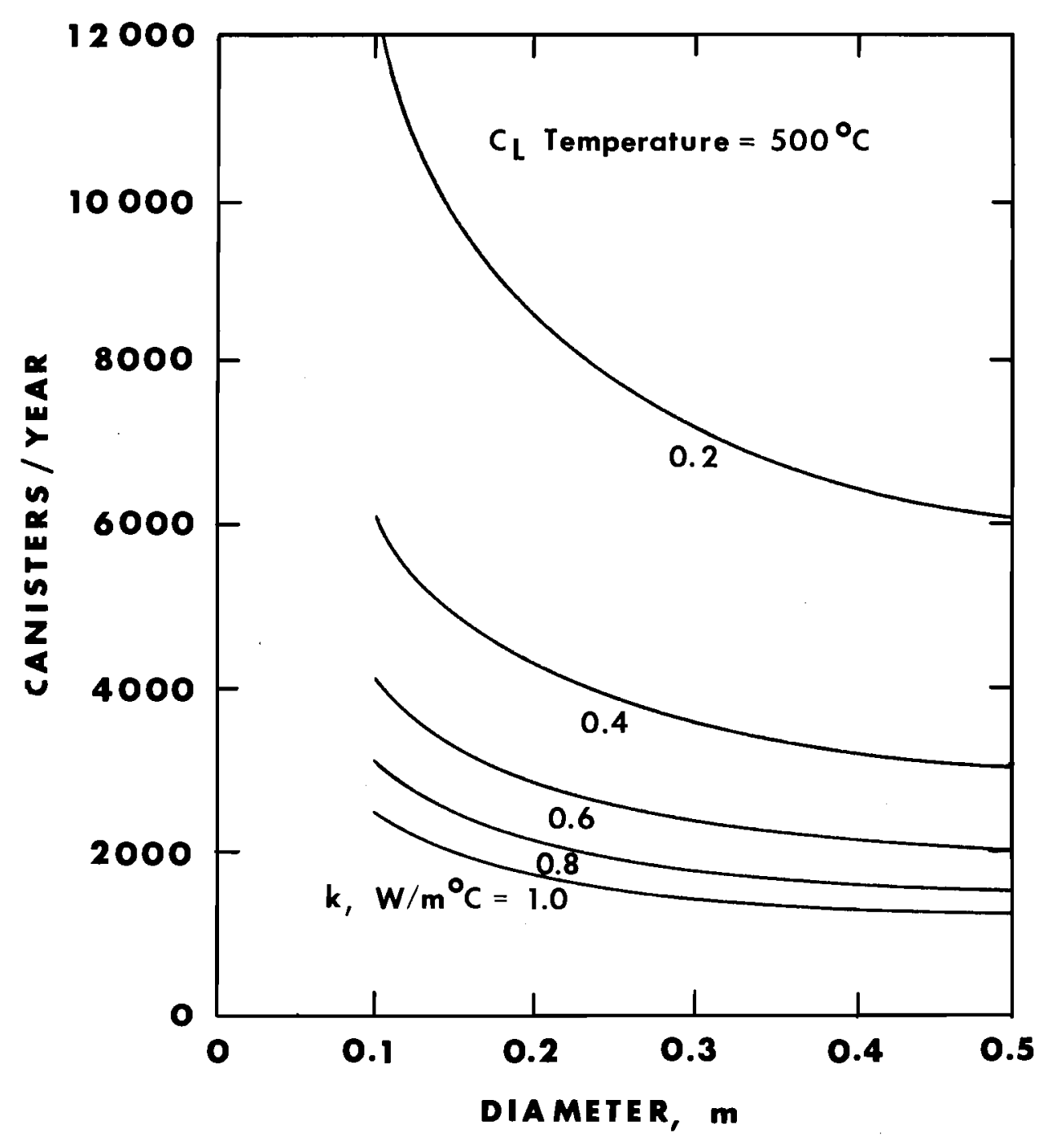

FIGURE 16. Number of Canisters Required per Year as a Function of Diameter and Thermal Conductivity 


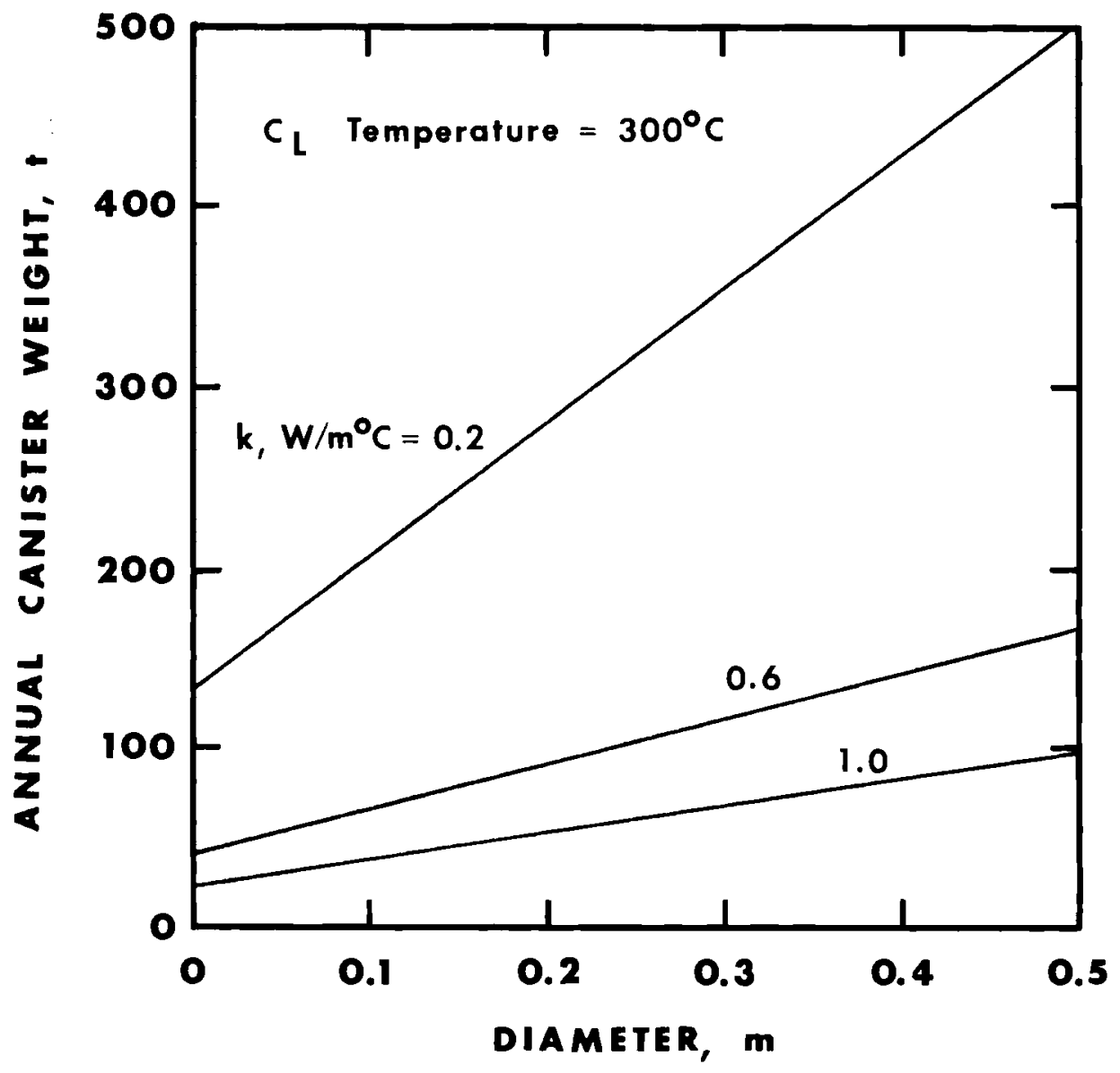

FIGURE 17. Annual Canister Weight as a Function of Diameter and Thermal Conductivity 


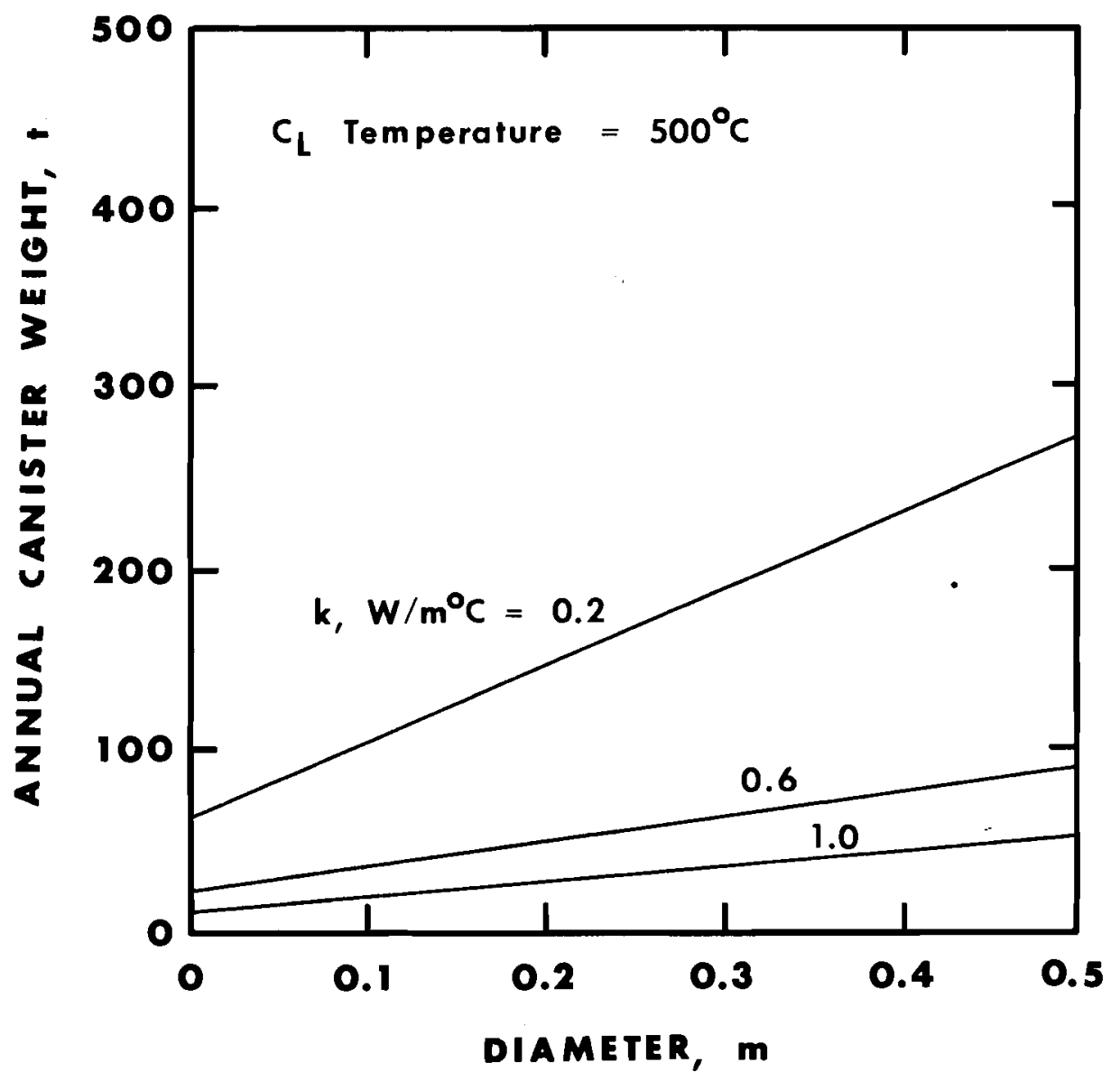

FIGURE 18. Annual Canister Weight as a Function of Diameter and Thermal Conductivity 


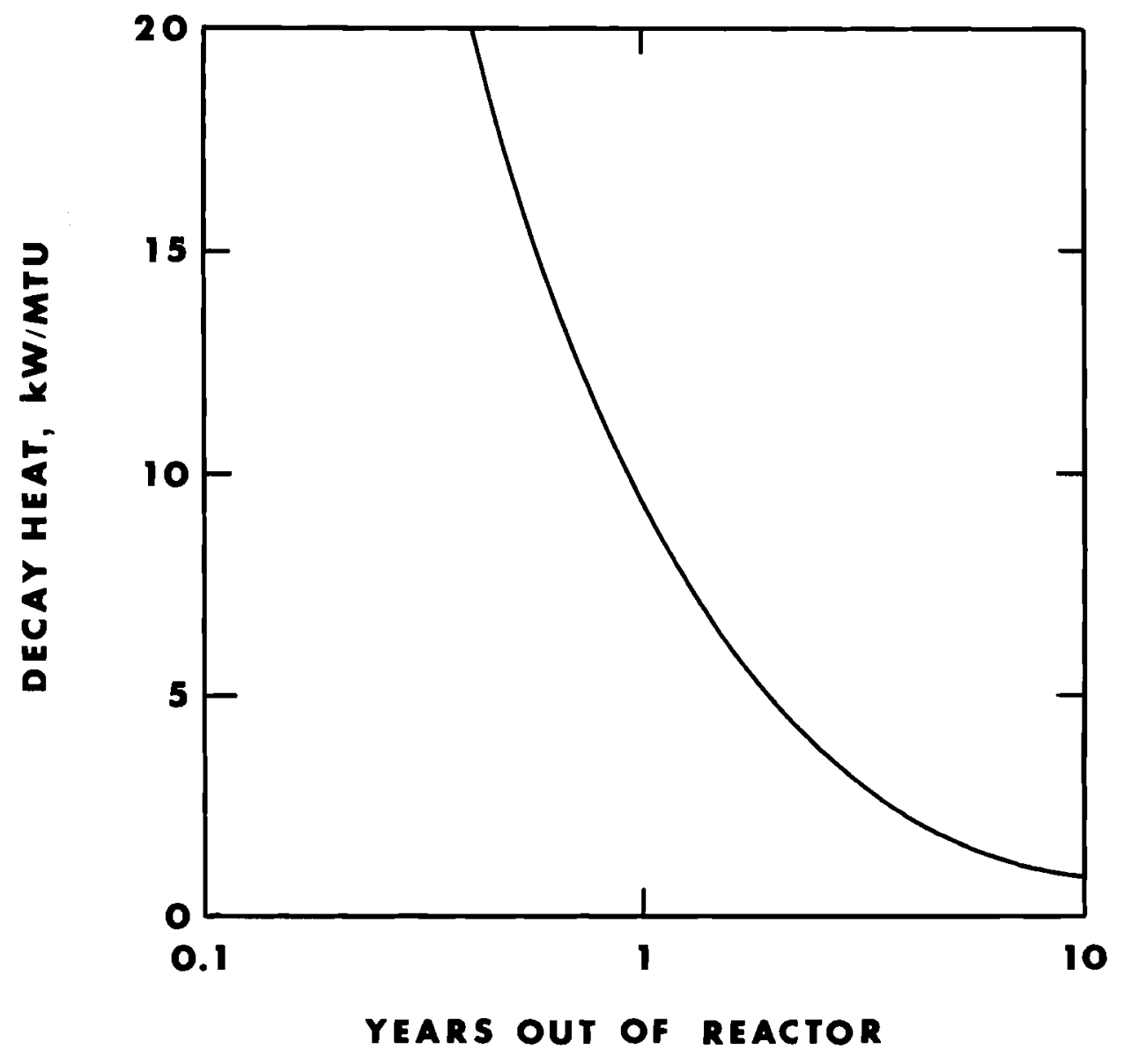

FIGURE 19. Radioactivity Decay Heat as a

Function of Time Out of Reactor 
TABLE 22. Requirements for the Immobilization of Radioactive Waste in Concrete

\begin{tabular}{|c|c|c|c|c|c|}
\hline & \multicolumn{5}{|c|}{ Years Out of Reactor } \\
\hline & 1 & $\underline{2}$ & $\underline{3}$ & $\underline{5}$ & 10 \\
\hline Diameter $^{\mathrm{a}}(\mathrm{m})$ & 0.3 & 0.3 & 0.3 & 0.3 & 0.3 \\
\hline Volume (L) & 212.2 & 212.1 & 212.1 & 212.1 & 212.1 \\
\hline Heat generation $(W / L)$ & 8.5 & 8.5 & 8.5 & 8.5 & 8.5 \\
\hline $\mathrm{kW} /$ canister & 1.8 & 1.8 & 1.8 & 1.8 & 1.8 \\
\hline Canisters/year & 7657.0 & 3911.7 & 2496.8 & 1414.9 & 715.8 \\
\hline Canisters/day & 25.5 & 13.0 & 8.3 & 4.7 & 2.4 \\
\hline Waste volume (L/canister) & 7.8 & 15.3 & 24.0 & 42.4 & 83.8 \\
\hline Volume percent waste & 3.7 & 7.2 & 11.3 & 20.0 & 39.5 \\
\hline Cement volume ( $L /$ canister) & 204.2 & 196.7 & 188.0 & 169.7 & 128.2 \\
\hline Cement volume $\left(\mathrm{m}^{3} /\right.$ year $)$ & 1563.7 & 769.5 & 469.5 & 240.0 & 91.8 \\
\hline Canister material weight $(\mathrm{kg})$ & 26.4 & 26.4 & 26.4 & 26.4 & 26.4 \\
\hline Canister material weight ( $t /$ year) & 202.1 & 103.2 & 65.9 & 37.3 & 18.9 \\
\hline Total weight ${ }^{\mathrm{b}}$ ( $\mathrm{kg} /$ canister) & 450.5 & 450.5 & 450.5 & 450.5 & 450.5 \\
\hline Total weight ${ }^{b}$ (t/year) & 3449.5 & 1762.3 & 1124.8 & 637.4 & 322.5 \\
\hline
\end{tabular}

a. Based on maximum centerline temperature of $200^{\circ} \mathrm{C}$ with thermal conductivity $=0.6 \mathrm{~W} / \mathrm{m}^{\circ} \mathrm{C}$

b. Bulk density of concrete waste form $=2.0 \mathrm{~kg} / \mathrm{L}$ 
TABLE 23. Requirements for the Immobilization of Radioactive Waste in Concrete

\begin{tabular}{|c|c|c|c|c|c|}
\hline & \multicolumn{5}{|c|}{ Years Out of Reactor } \\
\hline & 1 & 2 & $\underline{3}$ & $\underline{5}$ & 10 \\
\hline Diameter $^{\mathrm{a}}(\mathrm{m})$ & 0.0849 & 0.1412 & 0.1939 & 0.2849 & 0.4424 \\
\hline Volume $(L)$ & 17.0 & 47.0 & 88.6 & 191.2 & 461.1 \\
\hline Heat generation (W/L) & 50.0 & 25.5 & 16.3 & 9.2 & 4.6 \\
\hline $\mathrm{kW} /$ canister & 0.8 & 1.2 & 1.4 & 1.8 & 2.1 \\
\hline Canisters/year & 16243.4 & 5885.3 & 3115.8 & 1449.7 & 608.1 \\
\hline Canisters/day & 54.1 & 19.6 & 10.4 & 4.8 & 2.0 \\
\hline Waste volume (L/canister) & 3.7 & 10.2 & 19.3 & 41.4 & 98.7 \\
\hline Volume percent waste & 21.7 & 21.7 & 21.7 & 21.7 & 21.7 \\
\hline Cement volume (L/canister) & 13.3 & 36.8 & 69.3 & 149.8 & 362.5 \\
\hline Cement volume $\left(\mathrm{m}^{3} /\right.$ year $)$ & 216.0 & 216.5 & 216.1 & 217.2 & 220.4 \\
\hline Canister material weight $(\mathrm{kg})$ & 7.2 & 12.1 & 16.8 & 25.0 & 39.8 \\
\hline Canister material weight ( $t /$ year) & 117.2 & 71.3 & 52.3 & 36.2 & 24.2 \\
\hline Total weight ${ }^{\mathrm{b}}(\mathrm{kg} /$ canister $)$ & 41.2 & 106.1 & 194.0 & 407.4 & 962.1 \\
\hline Total weight ${ }^{b}(t /$ year $)$ & 669.2 & 624.2 & 604.4 & 590.6 & 585.1 \\
\hline
\end{tabular}

a. Based on a maximum centerline temperature of $200^{\circ} \mathrm{C}$ with thermal conductivity $=0.6 \mathrm{~W} / \mathrm{m}^{\circ} \mathrm{C}$

b. Bulk density of concrete waste form $=2.0 \mathrm{~kg} / \mathrm{L}$ 


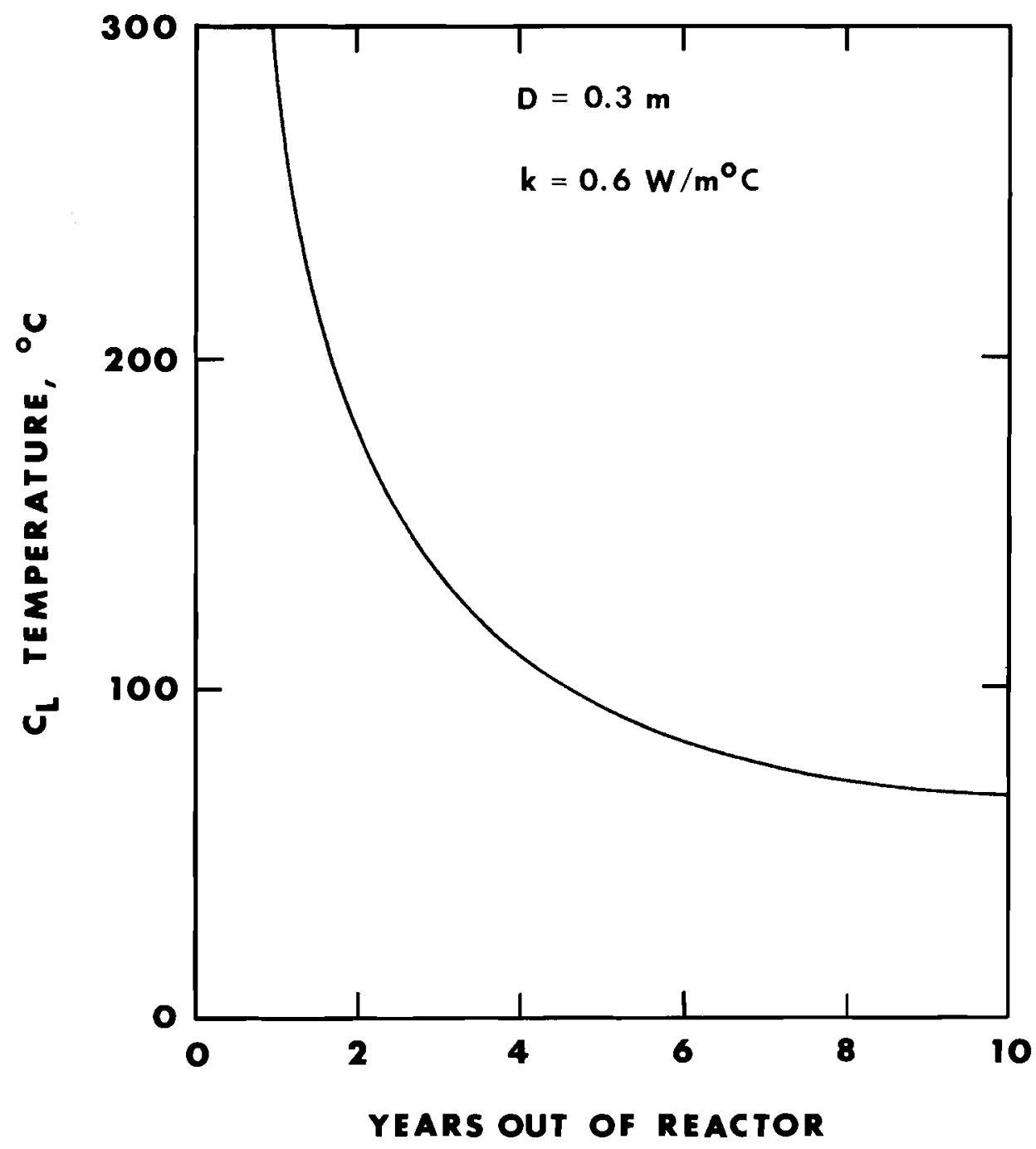

FIGURE 20. Canister Centerline Temperature as a Function of Time Out of Reactor 
TABLE 24. Comparison of Requirements for the Immobilization of Radioactive Waste in Concrete and Borosilicate Glass

\begin{tabular}{|c|c|c|c|c|c|c|}
\hline \multicolumn{3}{|c|}{ Concrete $^{a}$} & \multicolumn{4}{|c|}{ Borosilicate Glass } \\
\hline 0.3 & 0.2 & 0.1 & $0.185^{b}$ & $0.234^{\mathrm{C}}$ & $0.222^{d}$ & $0.279^{\mathrm{e}}$ \\
\hline 212.1 & 94.2 & 23.6 & 80.6 & 128.8 & 116.5 & 183.9 \\
\hline 8.5 & 15.6 & 40.5 & 153.3 & 153.3 & 115.0 & 115.0 \\
\hline 1802.5 & 1469.3 & 954.3 & 12362.2 & 19744.3 & 13402.3 & 21152.5 \\
\hline 7656.1 & 9392.1 & 14461.5 & 1116.3 & 698.9 & 1029.7 & 652.4 \\
\hline 25.5 & 31.3 & 48.2 & 3.7 & 2.3 & 3.4 & 2.2 \\
\hline 7.8 & 6.4 & 4.1 & - & - & - & - \\
\hline 3.7 & 6.8 & 17.6 & - & - & - & - \\
\hline 204.2 & 87.9 & 19.4 & - & - & - & - \\
\hline 1563.5 & 825.2 & 280.7 & - & - & - & - \\
\hline 26.4 & 17.3 & 8.5 & 16.0 & 20.4 & 19.3 & 24.5 \\
\hline 202.1 & 162.6 & 123.2 & 17.8 & 14.2 & 19.9 & 16.0 \\
\hline 450.5 & 205.8 & 55.6 & 282.0 & 445.3 & 403.9 & 631.5 \\
\hline 3449.1 & 1933.0 & 804.7 & 315.0 & 311.4 & 415.9 & 412.0 \\
\hline
\end{tabular}

a. Based on maximum centerline temperature of $200^{\circ} \mathrm{C}$ with thermal conductivity $=0.6 \mathrm{~W} / 1 \pi^{\circ} \mathrm{C}$

b. Centerline temperature $=800^{\circ} \mathrm{C}$; thermal conductivity $=0.9 \mathrm{~W} / \mathrm{m}^{\circ} \mathrm{C}$; heat generation $=153.3 \mathrm{~W} / \mathrm{L}$

c. Centerline temperature $=800^{\circ} \mathrm{C}$; thermal conductivity $=1.3 \mathrm{~W} / \mathrm{m}^{\circ} \mathrm{C}$; heat generation $=153.3 \mathrm{~W} / \mathrm{L}$

d. Cneterline temperature $=800^{\circ} \mathrm{C}$; thermal conductivity $=0.9 \mathrm{~W} / \mathrm{m}^{\circ} \mathrm{C}$; heat generation $=115.0 \mathrm{~W} / \mathrm{L}$

e. Centerline temperature $=800^{\circ} \mathrm{C}$; thermal conductivity $=1.3 \mathrm{~W} / \mathrm{m}^{\circ} \mathrm{C}$; heat generation $=115.0 \mathrm{~W} / \mathrm{L}$

f. Bulk density of concrete waste form $=2.0 \mathrm{~kg} / \mathrm{L}$; bulk density of glass monolith $=3.3 \mathrm{~kg} / \mathrm{L}$ 


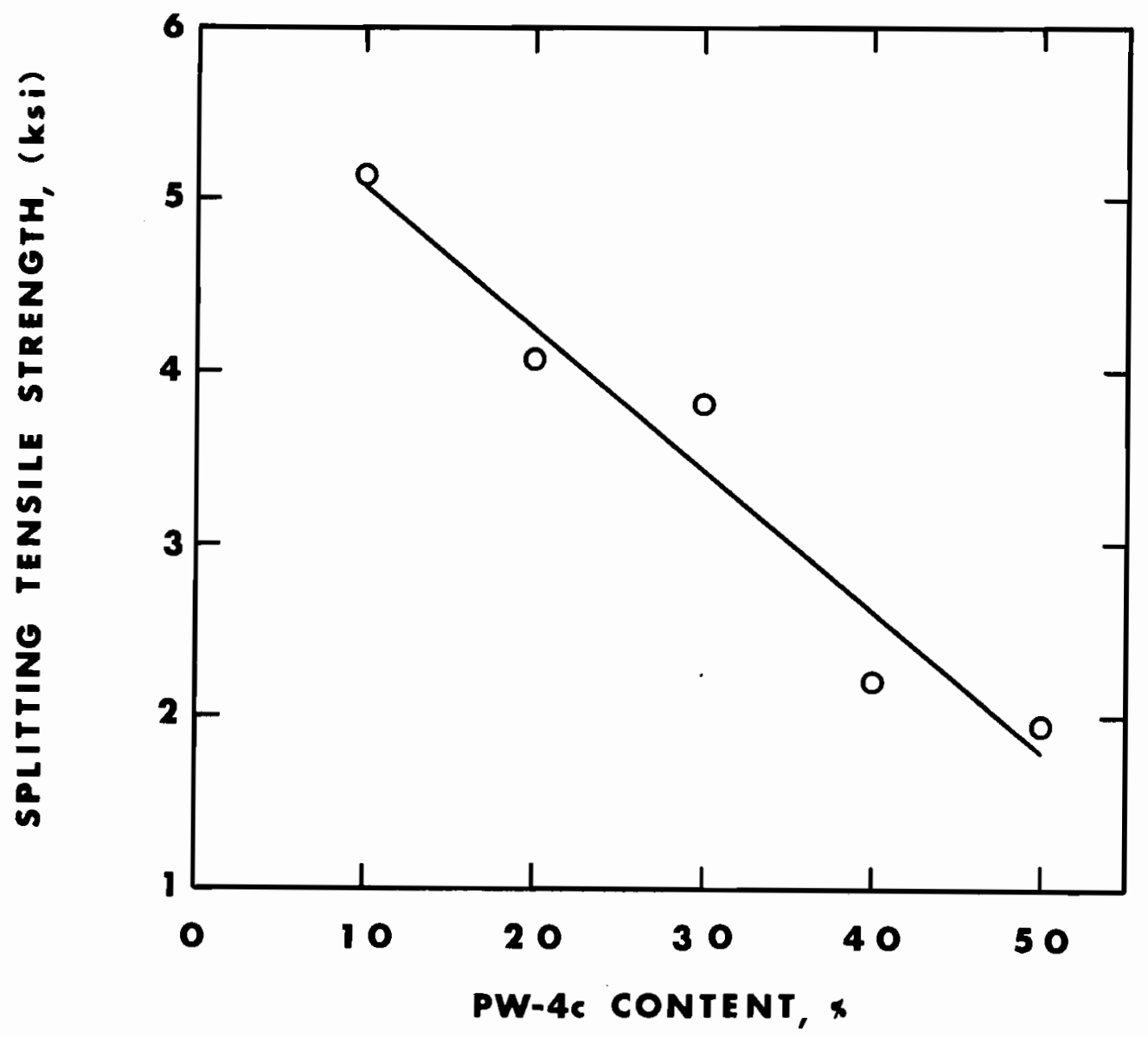

FIGURE 21. Splitting Tensile Strength of Hot-Pressed Cement Containing $\mathrm{PW}-4 \mathrm{C}$ 
TABLE 25. Requirements for the Incorporation of Radioactive Waste in Hot-Pressed Cement with a Limiting Temperature of $400^{\circ} \mathrm{C}$

\begin{tabular}{|c|c|c|c|c|c|}
\hline \multirow[b]{2}{*}{ Diameter $(m)$} & \multicolumn{5}{|c|}{ Hot-Pressed Cement $^{\mathrm{a}}$} \\
\hline & 0.2732 & 0.3143 & 0.3753 & 0.4790 & 0.7160 \\
\hline Volume (L) & 175.9 & 232.8 & 331.9 & 540.6 & 1207.9 \\
\hline Heat generation $(W / L)$ & 100.0 & 80.0 & 60.0 & 40.0 & 20.0 \\
\hline $\mathrm{kW} /$ canister & 17.6 & 18.6 & 19.9 & 21.6 & 24.2 \\
\hline Canisters/year & 784.7 & 741.1 & 693.0 & 638.2 & 571.2 \\
\hline Canisters/day & 2.6 & 2.5 & 2.3 & 2.1 & 1.9 \\
\hline Waste volume (L/canister) & 76.5 & 81.0 & 86.6 & 94.0 & 105.0 \\
\hline Volume percent waste & 43.5 & 34.8 & 26.1 & 17.4 & 8.7 \\
\hline Cement volume ( $L /$ canister) & 99.4 & 151.8 & 245.3 & 446.6 & 1102.9 \\
\hline Cement volume $\left(\mathrm{m}^{3} /\right.$ year $)$ & 78.0 & 112.5 & 170.0 & 285.0 & 630.0 \\
\hline Canister material weight $(\mathrm{kg})$ & 23.9 & 27.7 & 33.4 & 43.3 & 67.1 \\
\hline Canister material weight ( $t /$ year) & 18.8 & 20.5 & 23.2 & 27.7 & 38.4 \\
\hline Total weight ${ }^{b}$ (kg/canister) & 498.8 & 656.2 & 929.5 & 1503.0 & 3328.5 \\
\hline Total weight ${ }^{b}(t /$ year $)$ & 391.4 & 486.3 & 644.2 & 959.2 & 1901.4 \\
\hline
\end{tabular}

a. Based on maximum centerline temperature of $400^{\circ} \mathrm{C}$ with thermal conductivity $=2.5 \mathrm{~W} / \mathrm{m}^{\circ} \mathrm{C}$

b. Bulk density of hot-pressed cement waste form $=2.7 \mathrm{~kg} / \mathrm{L}$ 
TABLE 26. Requirements for the Incorporation of Radioactive Waste in Hot-Pressed Cement with a Limiting Temperature of $700^{\circ} \mathrm{C}$

$\underline{\text { Hot-Pressed Cement }}^{\mathrm{a}}$

$\begin{array}{lrrrr}\text { Diameter (m) } & 0.3 & 0.4 & 0.5 & 0.6 \\ \text { Volume (L) } & 212.1 & 377.0 & 589.0 & 848.2 \\ \text { Heat generation (W/L) } & 168.5 & 104.5 & 71.4 & 52.0 \\ \text { kW/canister } & 35.7 & 39.4 & 42.1 & 44.1 \\ \text { Canisters/year } & 389.2 & 350.3 & 328.1 & 312.9 \\ \text { Canisters/day } & 1.3 & 1.2 & 1.1 & 1.0 \\ \text { Waste volume (L/canister) } & 155.4 & 171.3 & 182.9 & 191.8 \\ \text { Volume percent waste } & 73.3 & 45.4 & 31.0 & 22.6 \\ \text { Cement volume (L/canister) } & 56.7 & 205.7 & 406.2 & 656.5 \\ \text { Cement volume (m/year) } & 21.9 & 72.1 & 133.3 & 205.4 \\ \text { Canister material weight (kg) } & 26.4 & 35.7 & 45.4 & 55.3 \\ \text { Canister material weight (t/year) } & 10.2 & 12.5 & 14.9 & 17.3 \\ \text { Total weight }{ }^{\text {(kg/canister) }} & 598.9 & 1053.6 & 1635.8 & 2345.5 \\ \text { Total weight }^{\text {(t/year) }} & 231.3 & 36.9 .1 & 536.7 & 733.8\end{array}$

a. Based on maximum centerline temperature of $700^{\circ} \mathrm{C}$ with thermal conductivity $=2.5 \mathrm{~W} / \mathrm{m}^{\circ} \mathrm{C}$ b. Bulk density of hot-pressed cement waste form $=2.7 \mathrm{~kg} / \mathrm{L}$ 
TABLE 27. Requirements for the Conceptual Process

for HLW Immobilization in Concrete

\begin{tabular}{|c|c|c|c|c|}
\hline & & ears Out & Reactor & \\
\hline & $1^{\mathrm{a}}$ & $5^{b}$ & $1^{a}$ & $5^{\mathrm{b}}$ \\
\hline Diameter (m) & 0.3048 & 0.3048 & 0.1524 & 0.1524 \\
\hline Volume $(L)$ & 218.9 & 218.9 & 54.7 & 54.7 \\
\hline Heat generation ${ }^{c}(W / L)$ & 8.3 & 8.3 & 23.0 & 23.0 \\
\hline $\mathrm{kW} /$ canister & 1.8 & 1.8 & 1.3 & 1.3 \\
\hline Canisters/year & 7602.9 & 1404.9 & 10987.9 & 2030.4 \\
\hline Canisters/day & 25.3 & 4.7 & 36.6 & 6.8 \\
\hline Waste volume (L/canister) & 7.9 & 42.7 & 5.5 & 29.6 \\
\hline Volume percent waste & 3.6 & 19.5 & 10.0 & 54.0 \\
\hline Cement volume ( $\mathrm{L} /$ canister) & 211.0 & 176.2 & 49.3 & 25.2 \\
\hline Cement volume $\left(\mathrm{m}^{3} /\right.$ year $)$ & 1604.3 & 247.5 & 541.3 & 51.1 \\
\hline Canister material weight $(\mathrm{kg})$ & 26.8 & 26.8 & 13.1 & 13.1 \\
\hline Canister material weight ( $t /$ year) & 204.0 & 37.7 & 143.9 & 26.6 \\
\hline Total weight $(\mathrm{kg} /$ canister $)$ & 464.6 & 464.6 & 122.5 & 122.5 \\
\hline Total weight ( $t /$ year) & 3532.5 & 652.8 & 1346.5 & 248.8 \\
\hline
\end{tabular}

a. Heat generation $=9200 \mathrm{~W} / \mathrm{MTU}$

b. Heat generation $=1700 \mathrm{~W} / \mathrm{MTU}$

c. Calculated for a maximum centerline temperature of $200^{\circ} \mathrm{C}$ with thermal conductivity $=$ $0.6 \mathrm{~W} / \mathrm{m}^{\circ} \mathrm{C}$ 


\section{REFEREINCES}

1. Alternatives for Managing Wastes from Reactors and Post-Fission Operations in the LWR Fuel Cycle, ERDA-76-43, Volume 1, United States Energy Research and Development Administration, May 1976.

2. Ibid., Volume 2 .

3. Treatment of Low- and Intermediate-Level Radioactive Waste Concentrates, Technical Report Series No. 82, STI/DOC/10/82, International Atomic Energy Agency, Vienna, Austria, 1968.

4. R. H. Burns, "Solidification of Low-and Intermediate-Level Wastes," Atomic Energy Review, Vo1. 9, pp. 547-599, 1971.

5. H. L. Loy and D. C. Saxena, "Processing and Packaging of Solid Wastes from BWR's," Proceedings of the Third International Symposium on Packaging and Transportation of Radioactive Materials, August 16-20, 1971, Richland, WA., CONF-710801, Vo1. 1, US AEC, pp. 478-489, 1971.

6. J. H. Leonard and K. A. Gablin, "Leachability Evaluation of Radwaste Solidified with Various Agents," Paper 74-WA/NE-8 presented at ASME Winter Annual Meeting, New York, November 17-22, 1974.

7. H. W. Heacock and J. W. Riches, "Waste Solidification--Cement or Urea Formaldehyde," Paper 74-WA/NE-9 presented at ASME Winter Annual Meeting, New York, November 17-22, 1974.

8. Commercial Alpha Waste Program Quarterly Progress Report OctoberDecember 1974, compiled by C. R. Cooley, HEDL-TME 74-41, Hanford Engineering Development Laboratory, Richland, WA, February 1975.

9. L. A. Emelity, J. R. Buchholz and P. E. McGinnis, Review of Radioactive Liquid Waste Management at Los Alamos, LA-UR-77-1195, Los Alamos Scientific Lab., NM, 1977.

10. B. Mandah1, B. Persson, and C. E. Wikdah1, Handling of Waste at Swedish Nuclear Plants, IAEA-CM-36-282, International Atomic Energy Agency, Vienna, Austria, 1977 (CONF 770505-217).

11. L. M. Mergan, M. Vandorpe, and N. Van deVoorde, Evaluation of Solidification Matrices Proposed for Nuclear Power Plant Radwaste, IAEA-CN36-186, Internationa 1 Atomic Energy Agency, Vienna, Austria, 1977 (CONF 77050-217).

12. R. M. Neilson, Jr., and P. Colombo, Solidification of Liquid Concentrate and Solid Waste Generated as By-Products of the Liquid Radwaste Treatment Systems in Light-Water Reactors, BNL-NUREG-22839, Brookhaven National Lab., Upton, NY, 1977. 
13. P. Colombo and R. M. Nielson, Jr., Properties of Radioactive Wastes and Waste Containers, Quarterly Progress Report, October-December, 1976, BNL-NUREG-50664, Brookhaven National Lab., Upton, NY, Apri1 1977.

14. J. G. Moore, H. W. Godbee, A. H. Kibbey and D. S. Joy, Development of Cementitious Grouts for the Incorporation of Radioactive Wastes, Part I, Leach Studies, ORNL-4962, Oak Ridge Nationa1 Lab., TN, Apri1 1975.

15. H. 0 . Weeren, Waste Disposal by Shale Fracturing at ORNL, CONF-77051213, Oak Ridge National Lab., TN, 1977.

16. Alternatives for Long-Term Management of Defense High-Level Radioactive Waste, Savannah River Plant, Aiken, South Carolina, ERDA-77-42, Energy Research and Development Administration, May 1977.

17. Alternatives for Long-Term Management of Defense High-Level Radioactive Waste, Idaho Chemical Processing Plant, Idaho Falls, Idaho, ERDA-77-43, Energy Research and Development Administration, September 1977.

18. Alternatives for Long-Term Management of Defense High-Level Radioactive Waste, Hanford Reservation, Richland, Washington, ERDA-77-44, Energy Research and Development Administration, Deptember 1977.

19. R. M. Wallace, H. L. Hull, and R. F. Bradley, Solid Forms for Savannah River Plant High-Level Waste, DP-1335, Savannah River Lab. Aiken, SC, December 1973.

20. Waste Management Quarterly Report, January-March, 1973, DPST-73-125-1, Savannah River Lab., Aiken, SC, 1973.

21. Waste Management, Savannah River Laboratory Quarterly Report, JanuaryMarch, 1974, DPST-74-125-1, Savannah River Lab., Aiken, SC, 1974.

22. Waste Management, Savannah River Laboratory Quarterly Report, Apri1June, 1974, DPST-74-125-2, Savannah River Lab., Aiken, SC, 1974.

23. Waste Management, Savannah River Laboratory Quarterly Report, JulySeptember, 1974, DPST-74-125-3, Savannah River Lab., Aiken, SC, 1974.

24. Waste Management, Savannah River Laboratory Quarterly Report, October-December, 1974, DPST-74-125-4, Savannah River Lab., Aiken, SC, 1974.

25. Waste Management, Savannah River Laboratory Quarterly Report, JanuaryMarch, 1975, DPST-75-125-1, Savannah River Lab., Aiken, SC, 1975. 
26. Waste Management, Savannah River Laboratory Quarterly Report, Apri1-June, 1975, DPST-75-125-2, Savannah River Lab., Aiken, SC, 1975.

27. Waste Management, Savannah River Laboratory Quarterly Report, July-September, 1975, DPST-75-125-3, Savannah River Lab., Aiken, SC, 1975.

28. Savannah River Laboratory Quarterly Report: Waste Management, January-March, 1976, DPST-76-125-1, Savannah River Lab., Aiken, SC, 1976.

29. J. A. Kelley, W. H. Hale, J. A. Stone and J. R. Wiley, Solidification and Storage of Savannah River Plant Radioactive Waste, DP-MS-75-19, Savannah River Lab., Aiken, SC, 1975 (CONF-751107-5).

30. R. M. Hallace and J. A. Kelley, Impact Test for Solid Waste Forms, DP-1400, Savannah River Lab., Aiken, SC, March 1976.

31. J. A. Stone and P. D. d'Entremont, Measurement and Control of Cement Set Times in Waste Solidification, DP-1404, Savannah River Lab., Aiken, SC, September 1976.

32. M. J. Plodinec, Evaluation of 137 Cs Sorbents for Fixation in Concrete, DP-1444, Savannah River Lab., Aiken, SC, February, 1977.

33. J. A. Stone, Evaluation of Concrete as a Matrix for Solidification of Savannah River Plant Waste, DP-1448, Savannah River Lab., Aiken, $\overline{S C}$, June 1977.

34. Savannah River Laboratory Long-Term Waste Storage Program, Progress Report No. 4, January-February 1974, BNL-18731, Brookhaven National Lab., Upton, NY, March 1974.

35. Savannah River Laboratory Long-Term Waste Storage Program, Progress Report No. 5, March-April 1974, BNL-18978, Brookhaven Nationa1 Lab., Upton, NY, June 1974.

36. P. Colombo, M. Steinberg, and B. Manowitz, Savannah River Laboratory Long-Term Waste Storage Program, Progress Report No. 8, OctoberDecember, 1974, BNL-19673, Brookhaven National Lab., Upton, NY, January 1975.

37. Savannah River Laboratory Long-Term Waste Storage Program, Progress Report No. 9, January-March 1975, BNL-20032, Brookhaven National Lab., Upton, NY, Apri1 1975.

38. P. Colombo and R. W. Neilson, Jr., Some Techniques for the Solidification of Radioactive Wastes in Concrete, BNL-21571, Brookhaven National Lab., Upton, NY, 1976 (CONF-760622-5). 
39. P. Colombo and R. M. Neilson, Jr., "Some Techniques for the Solidification of Radioactive Wastes in Concrete," Trans. Am. Nucl. Soc., 23. pp 161-162, June 1976 .

40. P. Colombo and R. M. Neilson, Jr., "Some Techniques for the Solidification of Radioactive Wastes in Concrete," Nucl. Technol., 32, pp 30-39, January 1977.

41. J. S. Kounts, Ed., Atlantic Richfield Hanford Company Quarterly Report, Technology Development for Long-Term Management of Hanford High-Level Waste, July-September 1975, ARH-ST-132A, Atlantic Richfield Hanford Co., Richland, WA, 1976.

42. J. S. Kounts, Ed., Atlantic Richfield Hanford Company Quarterly Report, Technology Development for Long-Term Management of Hanford High-Leve 1 Waste, January-March, 1976, ARH-ST-132C, Atlantic Richfield Hanford Co., Richland, WA, 1976.

43. Development of Durable Long-Term Radioactive Waste Composite Materials, Progress Report No. 5, October-December 1973, BNL-18652, Brookhaven National Lab., Upton, NY, January 1974.

44. Development of Durable Long-Term Radioactive Waste Composite Materials, Progress Report No. 6, January-March, 1974, BIIL-18830, Brookhaven National Lab., Upton, NY, Apri1 1974.

45. P. Colombo, M. Steinberg and B. Manowitz, Development of Long-Term Radioactive Waste Composite Materials, Progress Report No. 9, OctoberDecember 1974, BNL-19650, Brookhaven Nationà Lab., Upton, NY, January 1975.

46. P. Colombo, Development of Durable Long-Term Radioactive Waste Composite Materials, Progress Report No. 10, January-March 1975, BNL-20009, Brookhaven National Lab., Upton, NY, Apri1 1975.

47. J. R. Berreth, H. S. Cole, E. G. Samsel and L. C. Lewis, Status Report: Development and Evaluation of Alternative Treatment Methods for Commercial and ICPP High-Level Solidified Wastes, ICP-1089, Idaha National Engineering Lab., Idaho Fal1s, ID, May 1976.

48. M. Steinber, P. Colombo, and B. Manowitz, "Concrete-Polymer Materials Applied to Long-Term Storage of Radioactive Waste," Trans. Am. Nucl. Soc., 17, pp 333-334, November 1973.

49. Quarterly Progress Report, Research and Development Activities, Waste Fixation Program, October-December 1973, BNWL-1809, Battelle Pacific Northwest Laboratories, Richland, WA, January 1974. 
50. Quarterly Progress Report, Research and Development Activities, Waste Fixation Program, January-March 1974, BNWL-1826, Battelle Pacific Northwest Laboratories, Richland, WA, Apri1 1974.

51. Quarterly Progress Report, Research and Development Activities, Waste Fixation Program, April-June 1974, BNWL-1841, Battelle Pacific Northwest Laboratories, Richland, WA, July 1974.

52. D. M. Roy and G. R. Gouda, Hot Pressed Cement in Radioactive Waste Management, Final Report to Nuclear Waste Technology Program, Battelle Pacific Northwest Laboratories, Sub-Contract 841, August 1974.

53. E. A. Mershad, P. Colombo, W. W. Thomasson, and J. J. Dauby, "Packaging of Tritium-Contaminated Liquid Waste," Trans. Am. Nucl. Soc., 23, pp 163-164, June 1976.

54. P. Colombo, M. Steinberg and B. Manowitz, Tritium Storage Development. Progress Report No. 5, July-September 1975, BNL-20779, Brookhaven National Lab., Upton, NY, November 1975.

55. P. Colombo, R. Neilson, W. Becker and E. Divis, Tritium Storage Development. Progress Report No. 6, September-December 1975, BNL-21348, Brookhaven National Lab., Upton, NY, 1976.

56. Tritium Storage Development. Progress Report No. 7, January-March 1976, BNL-21700, Brookhaven National Lab., Upton, NY, 1976.

57. P. Colombo, Ed., Tritium Storage Development. Progress Report No. 8, Apri1-June 1976, BNL-50583, Brookhaven Nationa1 Lab., Upton, NY, 1976.

58. Tritium Storage Development. Progress Report No. 9, July-September, 1976, BNL-50625, Brookhaven National Lab., Upton, NY, 1976.

59. P. Colombo, R. Neilson, Jr., and M. Steinberg, "Fixation of Aqueous Tritiated Waste in Polymer-Impregnated Concrete and in Polyacetylene," CONF-750989-P3, Brookhaven National Lab., Upton NY, March 1976.

60. R. M. Neilson, Jr., P. Colombo, and W. Becker, Immobilization of Tritiated Aqueous Waste in Polymer Impregnated Concrete, BNL-22900, Brookhaven National Lab., Upton, NY, 1977.

61. R. M. Neilson, Jr., and P. Colombo, "Immobilization of Tritiated Aqueous Waste in Polymer-Impregnated Concrete," Trans. Am. Nucl. Soc., 26, p 290, June 1977.

62. W. E. Clark "The Isolation of Radioiodine with Portland Cement. Part I: Scoping Leach Studies," Nucl. Technol., 36, pp 215-221, December 1977. 
63. R. W. Benedict, An Evaluation of Methods for Immobilizing Solids Loaded with Krypton-85, ICP-1130, Idaho National Engineering Laboratory, Idaho Fal1s, ID, August 1977.

64. H. Matsuzuru, Y. Wadachi and A. Ito, Safety Evaluation of the Radioactive Waste-Cement Composites (4. Leaching behavior of T3TCs in crushed samples), JAERI-M 6749, Environmental Safety Research Laboratory, Reactor Safety Research Center, Tokai, JAERI, 1976.

65. K. Scheffler, et. al., Long-Term Leaching of Silicate Systems: Testing Procedure, Actinides Behaviour and Mechanism, KFK 2456, Karlsruhe, June 1977.

66. A. I. Nazarov (editor), V. V. Kulichenko, F. S. Dukhovich, 0. I. Volkova, M. V. Boyarinova, I. A. Sobolev, L. M. Khomchik and Y. M. Bazhenov, "The Problem of Fixation of Radioactive Wastes in Cement," IAEA Practices in Treatment of Low and Intermediate Level Radioactive Wastes, 12/6-10, 1965; (in Russion), BNWL-TR-297.

67. N. E. Bibler, Radiolytic Gas Production During Long-Term Storage of Nuclear Wastes, DP-MS-76-51, Savannah River Lab., Aiken, SC, 1976 (CONF-761002-3)

68. N. E. Bibler, Radiolytic Gas Production from Concrete Containing Savannah River Plant Waste, DP-1464, Savannah River Lab., Aiken, SC, January 1978.

69. A. P. Hoskins and J. R. Berreth, Heat Transfer Considerations in the Canister Storage of High-Level Solidified Wastes, ICP-1090, Idaho National Engineering Lab., Idaho Fal1s, ID, 1976.

70. R. P. Tye and S. C. Spinney, "Thermal Conductivity of Concrete: Measurement Problems and Effect of Moisture," I.I.F.-I.I.R., Commission B1, Washington 1976-2, pp 119-127, 1976. 
PNL -2654

UC -70

DISTRIBUTION

No. of

No. of

Copies

Copies

OFFSITE

UNITED STATES

A. A. Churm

DOE Chicago Patent Group

9800 South Cass Avenue

Argonne, IL 60439

S. H. Smiley

Deputy Director for Fuels and Materials

NRC Directorate of Licensing for Fuels and Materials

4915 St. Elmo Ave.

Bethesda, MD 20014

W. P. Bishop

Chief, Waste Management Branch

NRC Division of Materials and

Fuel Cycle Facility Licensing Washington, DC 20555

W. G. Belter

DOE Division of Biomedical and Environmental Research

Earth Sciences Branch

Washington, DC 20545

W. A. Brobst

DOE Division of Environmental

Control Technology

Washington, DC 20545

W. E. Mott

DOE Division of Environmental

Control Technology

Washington, DC 20545
G. W. Cunningham

Director, DOE Division of Waste Management, Production and

Reprocessing

Washington, DC 20545

R. B. Chitwood

DOE Division of Waste Management

Production and Reprocessing

Washington, DC 20545

C. A. Heath

DOE Division of Waste Management Production and Reprocessing Washington, DC 20545

G. Oertel

DOE Division of Waste Management

Production and Reprocessing

Washington, DC 20545

J. M. Taub

DOE Division of Waste Management

Production and Reprocessing

Washington, DC 20545

R. D. Walton

DOE Division of Waste Management

Production and Reprocessing

Washington, DC 20545

DOE Idaho Operations Office

PO Box 2108

Idaho Falls, ID 83401 
No. of

Copies

J. J. Schreiber

DOE Oak Ridge Operations Office

PO Box $X$

Oak Ridge, TN 37830

27 DOE Technical Information Center

A. P. Roeh, Manager

Process Evaluation Branch

Allied Chemical Corp.

550 2nd Street

Idaho Fal1s, ID 83401

J. R. Berreth

Allied Chemical Corporation

550 2nd Street

Idaho Fal1s, ID 83401

Allied Chemical Corporation

(File Copy)

550 2nd Street

Idaho Falls, ID 83401

J. A. Buckham

Allied-General Nuclear Services

PO Box 847

Barnwe11, SC 29812

A. Williams

Allied-General Nuclear Services

PO Box 847

Barnwe11, SC 29812

J. L. Jardine

M. J. Steindler/L. E. Trevorrow

2 Argonne National Laboratory

9700 South Cass Avenue

Argonne, IL 60439
No. of

Copies

Research Library

Battelle Memorial Institute

505 King Avenue

Columbus, $\mathrm{OH} 43201$

2 Brookhaven National Laboratory

Research Library

Reference Section

Information Division

Upton, Long Is land, NY 11973

Combustion Division

Combustion Engineering, Inc.

Windsor, CT 06095

2 M. A. Thompson

Rockwel1 International

Rocky Flats Division

Golden, CO 80401

M. D. Boersma

duPont Company, Aiken (DOE)

E. I. duPont DeNemours and Co.

Savannah River Laboratory

Aiken, SC 29801

C. H. Ice

duPont Company, Aiken (DOE)

E. I. duPont DeNemours and Co. Savannah River Laboratory

Aiken, SC 29801

A. S. Jennings

duPont Company, Aiken (DOE)

E. I. duPont DeNemours and Co.

Savannah River Laboratory

Aiken, SC 29801

P. H. Permar

duPont Company, Aiken (DOE)

E. I. duPont DeNemours and Co. Savannah River Laboratory

Aiken, SC 29801 
M. J. Plodinec duPont Company, Aiken (DOE)

E. I. duPont DeNemours and Co. Savannah River Laboratory

Aiken, SC 29801

L. Henning

Electric Power Research Institute

3412 Hillview Ave.

PO Box 10412

Palo Alto, CA 94304

Environmental Protection Agency

Technology Assessment Div. (AW-559)

Office of Radiation Programs

U.S. Environmental Protection Agency

Washington, DC 20460

R. G. Barnes

General Electric Company

175 Curtner Ave.

(M/C 160)

San Jose, CA 95125

L. H. Brooks

Gulf Energy and Environmental Systems

PO Box 81608

San Diego, CA 92138

2 Central Research Library Document Reference Section

Oak Ridge National Laboratory (DOE)

Oak Ridge, TN 37830

3 Los Alamos Scientific Laboratory (DOE)

P0 Box 1663

Los Alamos, NM 87544

C. J. Kershner

Monsanto Research Corporation

Mound Laboratory

PO Box 32

Miamisburg, $\mathrm{OH} 45342$
John Pomeroy

Technical Secretary

National Academy of Sciences

Committee of Radioactive Waste Management

National Research Council

2101 Constitution Avenue

Washington, DC 20418

2 J. P. Duckworth

Plant Manager

Nuclear Fuel Services, Inc.

PO Box 124

West Valley, NY 14171

J. G. Cline, General Manager

NYS Atomic and Space Development Authority

230 Park Avenue, Rm. 2425

New York, NY 10017

J. K. Johns tone

Sandia Laboratories

A1buquerque, NM 87107

W. Weart

Division 1140

Sandia Laboratories

A1buquerque, NM 87107

H. D. Sivinski

Sandia Laboratories

Albuquerque, NM 87107

J. 0. Blomeke

Union Carbide Corporation (ORNL)

Chemical Technology Division

P0 Box Y

Oak Ridge, TN 37830

2 D. E. Ferguson

Union Carbide Corporation (ORNL)

Chemical Technology Division

PO Box Y

Oak Ridge, TN 37830 
No. of

Copies

W. C. McClain

Union Carbide Corporation (ORNL)

Chemical Technology Division

PO Box $Y$

Oak Ridge, TN 37830

7 C. D. Zerby

Union Carbide Corporation

Nuclear Division

Office of Waste Isolation

PO Box Y

Oak Ridge, TN 37830

R. A. Beall

U.S. Department of Interior

Bureau of Mines

Albany Research Center

1450 W. Queen Avenue

Albany, OR 97321

S. E. Logan

University of New Mexico

Albuquerque, NM 87131

R. G. Post

College of Engineering

University of Arizona

Tucson, AZ 85721

G. J. McCarthy

Materials Research Laboratory

Pennsylvania State University

University Park, PA 16802

ONSITE - RICHLAND, WA 99352

5 DOE Richland Operations Office

R. B. Goranson

M. J. Shupe

D. J. Squires

M. J. Zamorski

H. E. Ransom
No. of

Copies

10 Rockwe11 Hanford Operations

H. Babad

R. A. Deju

R. J. Gimera

E. J. Kosiancic

M. J. Kupfer

C. M. Manry

J. H. Roecker

D. M. Strachen

D. D. Widrich

File Copy

\section{Exxon}

S. J. Beard

2 Joint Center for Graduate Study

J. Cooper

L. C. 01 sen

2 United Nuclear Industries, Inc.

T. E. Dabrowski

A. E. Engler

Westinghouse Hanford Company

A. G. Blasewitz

62 Battelle-Northwest

J. W. Bartlett

W. J. Bjorklund

H. T. Blair

W. F. Bonner

D. J. Bradley

J. L. Buelt

L. R. Bunne 11

C. C. Chapman

L. A. Chick

T. D. Chikalla

A. A. Garrett

E. R. Irish

J. H. Jarrett 
No. of

Copies

\section{Battelle-Northwest (cont'd)}

Y. B. Katayama

D. E. Larson

R. 0. Lokken (15)

J. M. Lukacs

R. P. Marshall

J. L. McElroy

G. B. Mellinger

J. E. Mendel

W. J. Mikols

R. E. Nightingale

D. E. Olesen

C. R. Palmer

A. M. Platt

D. L. Prezbindowski (2)

F. P. Roberts

W. A. Ross

J. M. Rusin (5)

D. H. Siemens

R. P. Turcotte

J. W. Wald

W. J. Weber

H. H. Van Tuyl

J. H. Westsik, Jr.

L. D. Williams

Technical Information (5)

Publishing Coordination (2) 
